\title{
KAMIENIE ZRODZONE Z PIORUNA. O NIETYPOWEJ FORMIE RECYKLINGU W ŚREDNIOWIECZU I CZASACH NOWOŻYTNYCH
}

\author{
STONES BORN OF LIGHTNING. ON AN UNUSUAL FORM OF RECYCLING \\ IN THE MIDDLE AGES AND MODERN TIMES
}

The article is an attempt to determine to what extent the folkloric and ethnographic data concerning the cultural significance and functions performed by re-used stone products hailing from prehistoric times (mainly various types of axes, hammers, adzes, and hammers axes, usually from the Neolithic, less often from other periods), are reflected in medieval and modern historical materials. Finds from almost all over Europe were taken into account. In the Middle Ages and later, thunderstones gained a great deal of importance, because there were few items that, after their original function had disappeared, remained in such wide use, far beyond traditionally understood recycling, which is usually limited to the re-use of raw materials and remedial actions. As objects of great sacred importance, they found a permanent place in the rituals and imaginations of ancient communities.

KEY WORDS: thunderstones, magical meaning, recycling, ethnography, prehistoric stone products

\section{WSTĘP}

Niemiecka badaczka A. Mehling w swej prezentacji archaików ${ }^{1}$ pochodzących z grobów merowińskich zaproponowała ich podział na cztery kategorie, z których jedna grupuje okazy spożytkowane wtórnie w ramach szeroko pojętego recyklingu. $\mathrm{Z}$ taką formą wykorzystania przedmiotu wiąże się jego ponowne

1 Tak określane są przedmioty o chronologii znacznie wyprzedzającej kontekst ich znalezienia. Na temat tego rodzaju artefaktów zob. ostatnio Knight et al. 2019; Kurasiński, Skóra 2020 (w pracach tych aktualna literatura). zastosowanie (zgodne z pierwotną funkcją), dalsze zastosowanie (w innej funkcji aniżeli pierwotna) oraz ponowne i dalsze zastosowanie (jako surowca sensu stricto do wykonania całkowicie nowej rzeczy) (Mehling 1998, 90-101). Wśród znalezisk, których dawne przeznaczenie zostało zapomniane, a jednocześnie sam kształt przedmiotu, pomimo ewentualnej ingerencji w jego strukturę, nadal umożliwia identyfikację formalną i chronologiczną, lokują się kamienie pradziejowe pozyskiwane i gromadzone w średniowieczu i czasach nowożytnych. Ich znaczeniem i adaptacją w zupełnie innych realiach kulturowych zajmiemy się w niniejszym artykule. Kwestia, której chcielibyśmy się przyjrzeć, sprowadza się do odpowiedzi na 
pytanie, na ile przekazy folklorystyczne i dane etnograficzne, dotyczące kulturowego znaczenia i funkcji pełnionych przez te przedmioty i ukazujące możliwości włączenia ich do ponownego obiegu, znajdują odzwierciedlenie w średniowiecznych i nowożytnych materiałach zabytkowych.

Zanim jednak przystąpimy do dalszej analizy, należy dokonać dookreślenia zakresu pojęciowego omawianego zbioru znalezisk i usystematyzowania go pod względem formalnym.

\section{ZAKRES POJĘCIOWY}

Omawiane przedmioty zazwyczaj określane są jako „kamienie piorunowe”", choć znanych jest wiele semantycznych i synonimicznych odpowiedników, uwarunkowanych językowo i regionalne. W polszczyźnie mamy przykładowo: kamień od pioruna, kamień spadty z nieba, kamyszek gromowy, pratek piorunowy, pradek, strzała (strzałka) piorunowa, kamienny palec, paluszek Boży (Pana Jezusa, Matki Boskiej), palec diabła, czarci palec, laska piorunowa, zęby pioruna, klin piorunowy, grom, grzmot. Większość określeń to dwuczłonowe zestawienia, z których pierwszy na ogół odnosi się do cechy przedmiotu (wydłużonego i zaostrzonego na końcu), drugi zaś akcentuje jego związek z piorunem, diabłem, rzadziej - Bogiem i świętymi (Mazurkiewicz 1988, 251-252; Brzozowska 1993; Szczepański 2010, 9). Niektóre z wymienionych nazw sięgają odleglejszych pokładów znaczeniowych, nawiązujących do słowiańskiego boga Peruna i jego kultu (Sieradzki 2017, 207208). Podobnie jest w innych językach słowiańskich. $\mathrm{Na}$ terenach ruskich rozpatrywane znaleziska często pojawiają się pod nazwami: gromowa strzała (ros. громова[я] стрела, ukr. громова стрілка), boża strzałka (ros. божья стрелочка), boży palec (białorus. божыцй пальчик), czarci palec (ros. чертов палец, ukr. чортів палець), strzałka św. Eliasza (ros. ильинская стрелка, стрелка Илии, ukr. стрелка св. Илии, białorus. Святого Илли страла), młotek kamienny (ros. каменный молоток, białorus. гега з дзірачкай)(Tolstoy 1995, 561; Gasanov 2018, 23-24;

2 Takim terminem posługiwać się będziemy w dalszej części pracy, zdając sobie sprawę z pewnej jego umowności wynikającej z funkcji przypisywanej omawianym obiektom. zob. także Mazurkiewicz 1988, 257). Po czesku zazwyczaj określa się je jako hromový kamen i hromový klin, rzadziej hromová střela, a po słowacku paromova strela (Skutil 1932, 37; Sklenáŕ 1999, 23). W Słowenii wyorywane na polach pradziejowe topory i siekiery zwano smoczymi zębami (zmajev zob) (Šmitek 2007, 182), a w Dalmacji na omawiane przedmioty mówiono kamen svetog Pavla (Tolstoy 1995, 561-562). W językach germańskich i romańskich ujawnia się związek z bóstwem piorunowym (lub samym piorunem i grzmotem), którego atrybut został wyobrażony m.in. jako kamień, topór, klin, maczuga bądź dłuto; zob. np. szw.: torvigge, thornkilen, torenvigg, torkil, godvigg, åskvigg, åskkil, åskpil, duń.: tordenbolt, tordensten, tordenkølle, tordenkile, norw.: torebløyg, torestein, torelod, torekik, toreblyg, niderl.: donderbeitel, donderkeil, dondersteen, niem.: Donneraxt, Donnerbeile, Donnerkeil, Donnerhammer, Donnersteine, Strahlsteine, Teufelsfinger, ang.: thunderbolt, thunderaxe, thunderhammer, thunderstone, thunderflone, franc.: pierre d'orage, pierre de tonnere, pierre de foudre, hiszp.: piedras de rayo (np. Kirchner 1853, 62; Cartailhac 1878, 10; Červinka 1897a, 48; Olbrich 1987, 325; Lequellec 1996, 291-292; Carelli 1997, 400-401; Motz 1997, 342; Unger 2007, 14; Rúa Aller, García Armesto 2010, 63). Podobnie na Litwie, gdzie kamienie piorunowe funkcjonowały m.in. jako Perkūno kulka, Perkūno kirvelis, Perkūno strèle (Laurinkienè 1996a, 23; Laurinkienè 1996b, 105).

Warto mieć na uwadze, iż pod powyższymi określeniami mieścić się może cały szereg innych znalezisk (zob. Erich, Beitl 1955, 135; Carelli 1997, 400401; Olbrich 1987, 326; Tolstoy 1995, 561; Simpson, Roud 2000, 359; Wdowiak, Wysokiński 2013, 530534; Hála 2016a, 42; Ofrim 2019, passim). Chodzi tu głównie o skamieniałości pochodzenia organicznego, przede wszystkim belemnity ${ }^{3}$ i echinity ${ }^{4}$. Mogą to być także obiekty nieorganiczne, jak meteoryty, kryształy siarki, fulguryty ${ }^{5}$, a ponadto naturalne kamienie kształ-

3 Skamieniałe rostrum tego gatunku głowonoga morskiego jest bardzo często uznawane za kamień piorunowy (zob. np. Hegele 1997; Lebeda 2002, 135-143; Banasiak 2017a; Banasiak 2017b; Banasiak 2018; Tsapko 2017).

4 Kopalna skamienielina skorupiaków i jeżowców morskich. Na temat ich kulturowego znaczenia, w tym jako kamieni piorunowych, zob. Blinkenberg 1911, 77-83, 84-85; Demnard, Néraudeau 2001; McNamara 2007.

5 Twór powstały wskutek stopienia piasku kwarcytowego po uderzeniu pioruna (zob. Szafrańska 2016). 
tem przypominające wyroby pradziejowe ${ }^{6}$. W słowiańskiej tradycji okazjonalnie pojawiają się ponadto m.in. stalaktyty (sopleńce), kryształ górski, szczapki z drzewa trafionego piorunem (Gasanov 2018, 10, 20$22)^{7}$ oraz kawałki rudy (Plessingerová, Vařeka 1999, 210). Według niektórych zapatrywań, wszelkiego rodzaju kamienne artefakty pradziejowe o zwracającej uwagę formie lokują się auf der Grenze zu den Naturprodukten (Hoffmann-Krayer 1921, 59). Warto dodać, iż rejestrowane są obiekty archeologiczne, w których wyroby z kamienia i fosylia współwystępowały ze sobą, pełniąc tę samą bądź zbliżoną funkcję magiczną (John 2003, 17; zob. także Samdal 2000, 51, 76-77; Johanson 2018a, 134).

Ze względu na wieloznaczny charakter kamieni piorunowych nie zawsze można mieć pewność, jaki konkretnie rodzaj znaleziska występuje pod daną na$z_{\text {wą }}^{8}$. Właściwej identyfikacji nie ułatwia też podawany niekiedy w przekazach folklorystycznych opis przedmiotu, gdyż stopień jego ogólności uniemożliwia stwierdzenie, czy mamy do czynienia ze skamieliną, nietypowym kamieniem czy kamiennym narzędziem (por. Johanson 2018a, 64).

Jak nadmieniono, w polu naszych zainteresowań znajdują się wyroby kamienne, a wśród nich przede wszystkim różnego rodzaju siekiery, topory, ciosła, młoty i siekieromłoty ${ }^{9}$. Niektóre okazy wyróżniają się wyrytymi znakami, symbolami i innymi motywami.

6 Według jednej z XIX-wiecznych definicji kamienie piorunowe to Beile aus der Steinzeit oder von Natur keilhammer oder keilförmig gestaltete Steine (Busch 1877, 165; zob. także Hukantaival 2018, 186, 190; Hukantaival 2019, 354; Johanson 2018b).

7 Wyjątkowo także inne cząstki drewna, głównie olszyny (Skutil 1932, 37; por. Reitinger 1976, 531).

8 Dawniej zdawano sobie jednak sprawę z różnic. Przykładowo, Mazurzy bardzo dobrze rozróżniali „,boże prątki” (Gottesstäbchen), czyli małe krzemyki w kształcie palców, zapewne belemnity, od „klinów piorunowych” (Donnerkeule), będących kamiennymi toporami lub podobnymi do nich obiektami (Toeppen 1867, 43).

9 Z prezentacji wyłączono przedmioty wykonane z krzemienia, przede wszystkim groty strzał i oszczepów, choć wiadomo, że występowały one w podobnych kontekstach, co pradziejowe wyroby kamienne i znaczeniowo były im pokrewne (np. Sedova 1957; Hall 2005; Eijk van 2007; Watte, Jullien 2007). Pominięto również przedmioty metalowe, wśród których do najczęściej spotykanych należą topory i siekiery, rzadziej groty strzał i włóczni oraz miecze (np. Penney 1976, 71-72; Reitinger 1976, 520; Fröhlich 1992, 240; Hukantaival 2016, 185; Rustoiu 2015; Dowd 2018, 463).
Należało uwzględnić także ich imitacje oraz wyroby nieudane lub nieukończone. Jako cechę kamieni piorunowych niekiedy uznaje się obecność otworów do umocowania drewnianego trzonka (Olbrich 1987, 326), jak jednak będzie się można przekonać, nie odnosi się to do wszystkich analizowanych wyrobów pradziejowych.

Pod uwagę wzięto materiał pochodzący z całej Europy, aczkolwiek w niniejszym artykule niemożliwe jest zaprezentowanie znanych i udokumentowanych zasobów źródłowych w ich pełnym zakresie. Stąd w dalszej części posłużymy się jedynie wybranymi przykładami. Warto dodać, iż z wierzeniami związanymi z kamieniami piorunowymi w rozumieniu odległych czasowo narzędzi kamiennych spotykamy się niemal na całym świecie (zob. np. Blinkenberg 1911; Lagercrantz 1940; Höltker 1944; Seonbok 2002; Jesse 2003; Lozkina 2005; Malakhova 2009; Brumm 2018). Już R. Andree zauważył, że Man wird überrascht, den Neger, den südamerikanischen Indianer, den Birmanen, den Esten, den Letten, den Deutschen, den Franzosen u. s. w. genau in demselben Aberglauben befangen zu finden, der sich auf die Entstehung und die angeblichen wunderbaren Eigenschaften der alten Steinbeile bezieht (Andree 1889, 30).

Dokonany przegląd znalezisk, jakkolwiek daleki od kompletności, pozwala jednak wskazać na główne rejony ich występowania, dając pojęcie o skali badanego fenomenu, zarówno $\mathrm{w}$ aspekcie chronologicznym, jak i terytorialnym.

\section{SUMARYCZNY PRZEGLĄD ZNALEZISK}

Wiele interesujących okazów pozyskano z Czech, Moraw i Słowacji. Już z okresu wczesnosłowiańskiego (kultura praska) pochodzą dwie siekiery neolityczne z półziemianki (nr 1444) w Roztokach niedaleko Pragi. Jedną z nich zlokalizowano przy ścianie w pobliżu kamiennego paleniska. Druga zalegała w warstwie pod podłogą w południowo-wschodnim narożniku ziemianki. W obiekcie (nr 1496) odnotowano jeszcze jeden egzemplarz, przy czym jego interpretacja jako kamienia piorunowego jest niepewna (ryc. 1:1-2)(Unger 2007, 27, 36-37, ryc. 21-22:2-3, fot. $1-3,6-9)$. Na kamienne wyroby pradziejowe natrafiono ponadto w kilku jamach zasobowych (Profantová 2005, 206). 


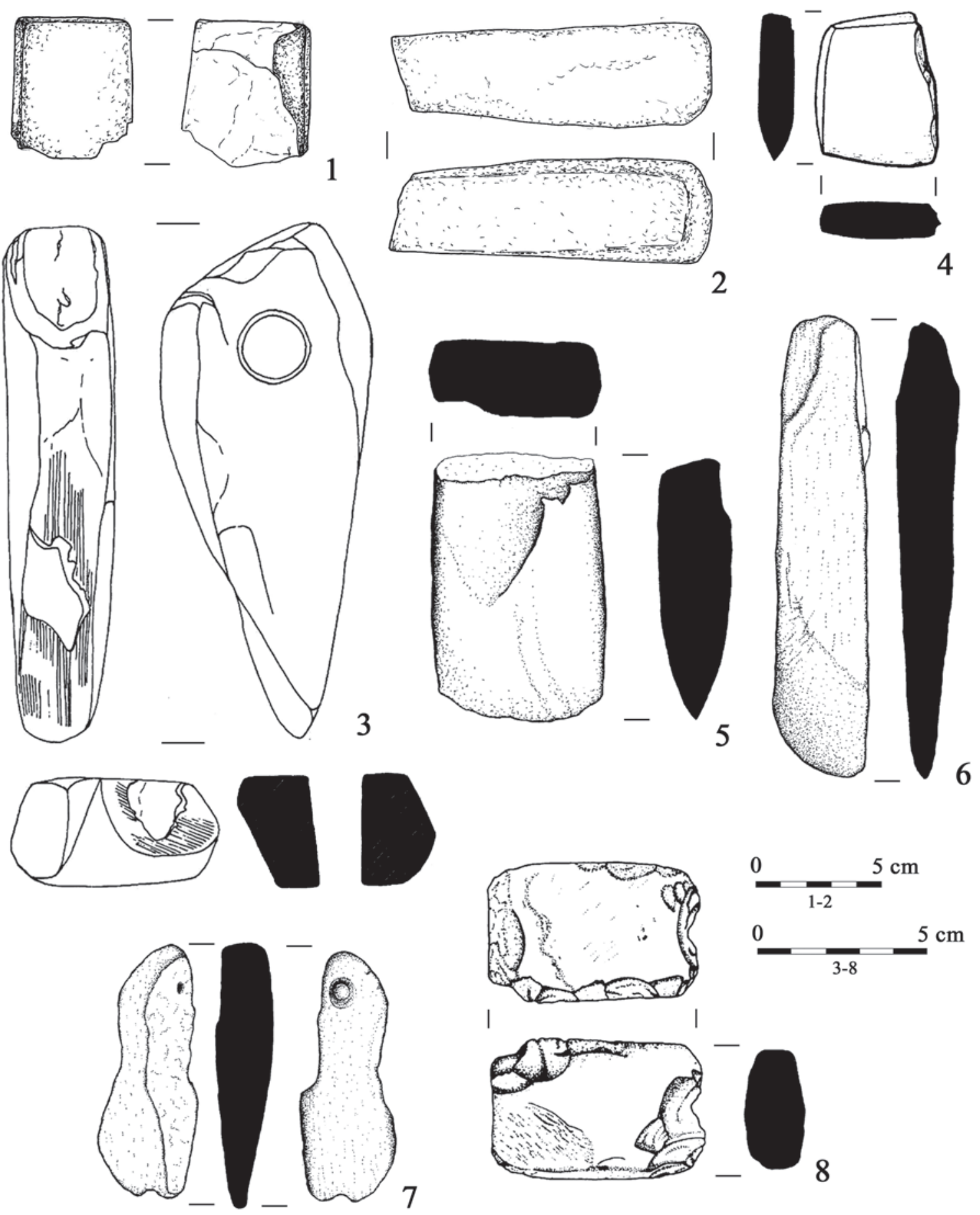

Ryc. 1. Kamienie piorunowe z terenu Czech: 1-2 - Roztoky (wg Unger 2007, ryc. 22:2-3); 3 - Křivoklát (wg Durdík 1997, ryc. 2:1); 4 - Čtyřkol (wg Hložek, Menšík 2009, ryc. 2); 5-7 - Kozí Hrádek (wg Hložek, Menšík 2009, ryc. 6-8); 8 - Týŕov (wg Hložek, Menšík 2014a, ryc. 3). Ryc. 1-2 skala przybliżona. Oprac. T. Kurasiński Fig. 1. Thunderstones from the Czech Republic: 1-2 - Roztoky (after Unger 2007, Fig. 22: 2-3); 3 - Křivoklát (after Durdík 1997, Fig. 2:1); 4 - Čtyřkol (after Hložek, Menšík 2009, Fig. 2); 5-7 - Kozí Hrádek (after Hložek, Menšík 2009, Fig. 6-8); 8 - Týřov (after Hložek, Menšík 2014a, Fig. 3). Fig. 1-2 scale approximate. By T. Kurasiński

Znacznie więcej okazów odnotowano w obrębie średniowiecznych i nowożytnych fortyfikacji, a także wsi i miast.
Na terenie Czech neolityczny siekieromłot ujawniono w warstwie destrukcyjnej późnogotyckiej Złotej Baszty na zamku Křivoklát, wiążącej się z pozo- 
stałościami szczytowej jej partii, gdzie pierwotnie przedmiot najprawdopodobniej się znajdował. Umiejscowiono go tam w horyzoncie czasowym wyznaczonym przez budowę wieży na przełomie XV i XVI w., a latami 40. XVII w., kiedy budowla uległa niewielkiemu pożarowi. Zabytek wiązany jest z kulturą ceramiki sztrychowanej (ryc. 1:3) (Durdík 1997). Fragment kamiennej siekiery znaleziono także w obrębie zamku w Čtyřkol (ryc. 1:4) (Durdík 2007, 214-215). Kolekcję złożoną z trzech neolitycznych i eneolitycznych(?) kamieni piorunowych odnotowano na zamku Kozí Hrádek, przy czym znane są okoliczności odkrycia tylko jednego okazu. Zalegał on w warstwie śmietniskowej $\mathrm{w}$ rejonie przedzamcza, w pobliżu zamkowej kuchni (ryc. 1:5-7) (Hložek, Menšík 2009). Z kolei na zamku Týřov w kamiennej warstwie destrukcyjnej przylegającej do zewnętrznego lica ściany wschodniego muru grodzącego przy okrągłej wieży zamku górnego, gdzie natrafiono na ślady bliżej nieokreślonej konstrukcji zrębowej, wydobyto narzędzie z wulkanitu. Było to zapewne eneolityczne kowadełko używane do produkcji miedzianych i złotych ozdób (ryc. 1:8) (Hložek, Menšík 2014a). Z innych znalezisk wymienić należy neolityczny topór ze średniowiecznej warowni w pobliżu wsi Vepice oraz dwa eneolityczne topory $\mathrm{z}$ warstwy XVI-wiecznego materiału ceramicznego na zamku Rudolfa II w Opočnie koło Stará Boleslav (Fröhlich 1992, 243; Hložek, Menšík 2009, 66). Być może funkcje kamienia gromowego pełnił też zachowany fragmentarycznie siekieromłot znaleziony na zamku Holoubek w Třebenicach (Dejmal et al. 2018).

Kilka z nich pochodzi z wiejskich i miejskich domostw, niektórych o metryce średniowiecznej. Na kamienny topór natrafiono pod podłogą w otworze fundamentowej belki w Rusavie (Cervinka 1897; Sklenár 1999, 54). W południowoczeskich Marčovicach pod progiem domu nr 7 znaleziono fragment eneolitycznego topora (ryc. 2:1) (Fröhlich 1992, 240, 242, ryc. 4:4). Taką sytuację potwierdzono w Podiebradach (Sklenáŕ 1999, 54). Również w czasie przebudowy domu nr 68 we wsi Panoší Újezd (Czechy Środkowe) odkryto wczesnoneolityczny siekieromłot, który prawdopodobnie zalegał pod progiem w części piwnicznej budynku (ryc. 2:2) (Vích, Kašpar 2014). Z kolei w Litenčicach na neolityczne narzędzie kopytowate (kopytovitý klinek) natrafiono w dołku posłupowym po jednym ze średniowiecznych budynków (Fojtík, Popelka 2018). Wybierano też inne miejsca. Przy kalenicy umieszczono siekiery $\mathrm{w}$ domach $\mathrm{w}$ miejscowościach Štrampouch i Suchdol (Sklenář 1999, 57;
Hložek, Menšík 2009, 65). W Milešovie znaleziono neolityczne narzędzie w kształcie kopyta na poddaszu domu nr 75 (ryc. 2:3) (Fröhlich 1992, 239, 242, ryc. $4: 2$ ). Podobnie było w przypadku innych neolitycznych wyrobów: siekieromłota z Prachatic (ryc. 2:4) (Fröhlich 1992, 243, ryc. 4:3) i siekiery z Železnej Rudy (ryc. 2:5) (Menšík 2018). Topór z łupku spoczywał za więźbą dachową domku nr 7 w miejscowości Brtec w powiecie Písek (Fröhlich 1992, 239, 241). Kolejny wczesnoneolityczny siekieromłot znaleziono w ruinach opuszczonego domu w Černá v Pošumaví (Menšík 2010b, 40). W Kolvínie siekierę z wczesnego neolitu odkryto $\mathrm{w}$ murze jednego $\mathrm{z}$ domostw (ryc. 2:6) (Sklenáŕ 1986, 5, tab. I:11; Fröhlich 1992, 240, 241). Z kolei w Žíšovie mocno zniszczony okaz pochodzący z neolitu znaleziono podczas rozbiórki domu w ścianie nad drzwiami (Fröhlich 1992, 240, 243).

Egzemplarze, które można uznać za kamienie piorunowe, stwierdzono także w zabudowaniach gospodarczych, takich jak stodoły czy obory (np. Dolní Bukovsko, Pročevily) (Fröhlich 1992, 240, 243; Unger 2007, 29, 42, 49). Trzymano je także w kuźniach, jak np. siekieromłot z późnej epoki kamienia we wsi Fryšava pod Žákovou horou (Doušek 2011, 165, ryc. 1).

Znamy też inne okoliczności ujawnienia omawianych artefaktów. W Cáslaviu dwa neolityczne narzędzia $\mathrm{z}$ amfibolitu odkryto $\mathrm{w}$ fundamentach gospody na przedmieściach Jeníkova, ponadto siekierę z tego okresu wydobyto ze studni domu nr 37, a jeszcze jedną znaleziono w naczyniu z XIV-XV w. (ryc. 2:7-8) (Čermák 1907, 510, 511, ryc. 2, 4). Na siekieromłot natrafiono także w Hradcu Králové w czasie wyburzania starego ratusza z 1786 r. Kontekst wskazuje, że przedmiot został umieszczony w murze lub na dachu budynku (Unger 2007, 30). Z kolei w mieście Písek została podczas naprawy gotyckiego mostu, przy jednym z jego filarów została wybagrowana uszkodzona kamienna motyka. Zabytek wiązany jest z kulturą ceramiki sztrychowanej (ryc. 2:9) (Fröhlich 1992, 242, ryc. 4:1; Fröhlich 2015, 35).

Kilka okazów kamieni gromowych pozyskanych w XIX i na początku XX w. znajduje się także w zbiorach etnograficznych Zachodnioczeskiego Muzeum w Pilźnie (Menšík 2014).

Na Morawach zespół wyrobów pradziejowych (siekiery i ich ułamki, fragment topora-młota i grot strzały z rogowca) stwierdzono na podgrodziu w Mikulčicach (ryc. 3:1-5) (Medunová-Benešová 1997, $110,128,129$, ryc. 14:1-2, 5-7). Według Š. Ungermana przedmioty dostały się tu wtórnie (Ungerman 2009, 

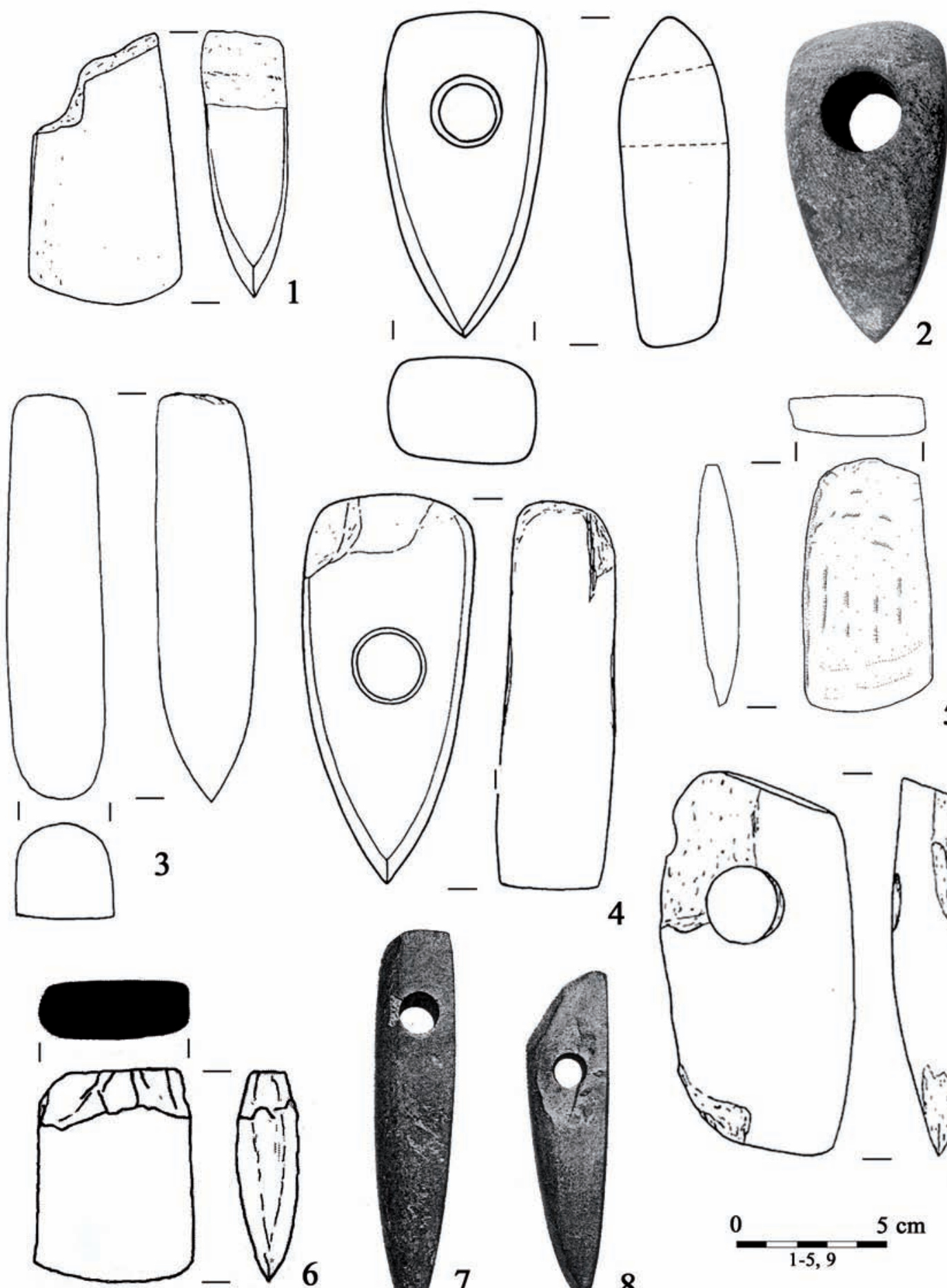

4
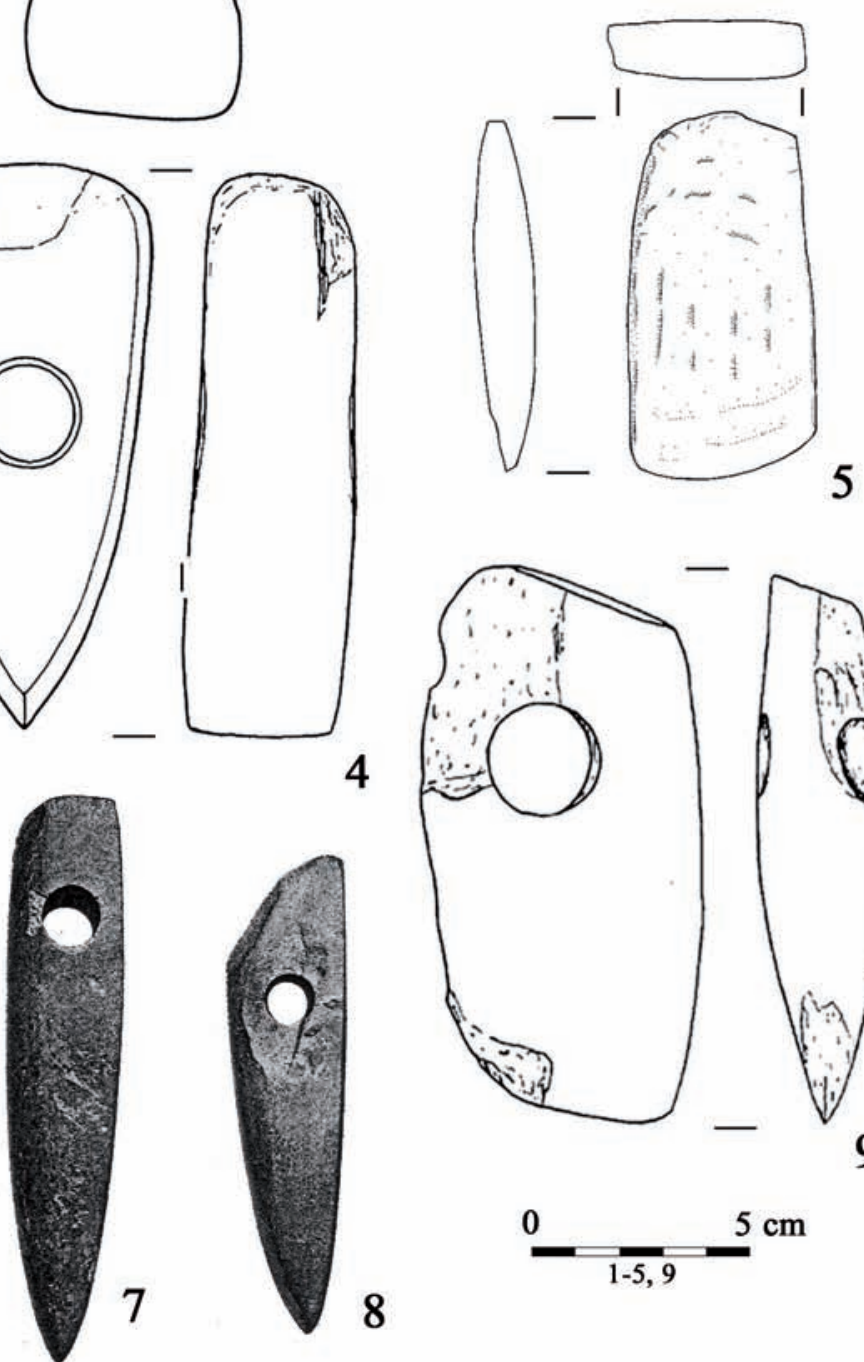

5
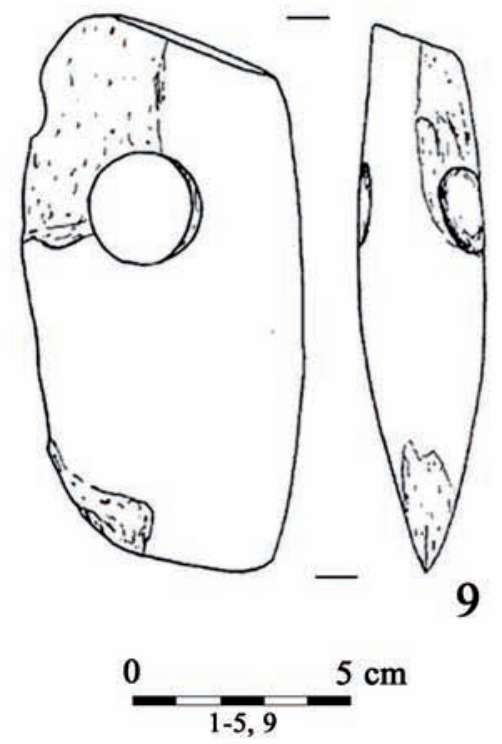

8

Ryc. 2. Kamienie piorunowe z terenu Czech: 1 - Marčovice (wg Fröhlich 1992, ryc. 4:4); 2 - Panoší Újezd (wg Vích, Kašpar 2014, ryc. 2); 3 - Milešov (wg Fröhlich 1992, ryc. 4:2); 4 - Prachatice (wg Fröhlich 1992, ryc. 4:3); 5 - Železná Ruda (wg Menšík 2018, ryc. 2); 6 - Kolvín (wg Sklenář 1986, tab. I:11); 7-8 - Cáslav (wg Čermák 1907, ryc. 2, 4); 9 - Písek (wg Fröhlich 1992, ryc. 4:1). Ryc. 6-8 nieskalowane. Oprac. T. Kurasiński

Fig. 2. Thunderstones from the Czech Republic: 1 - Marčovice (after Fröhlich 1992, Fig. 4:4); 2 - Panosí Újezd (after Vích, Kašpar 2014, Fig. 2); 3 - Milešov (after Fröhlich 1992, Fig. 4:2); 4 - Prachatice (after Fröhlich 1992, Fig. 4:3); 5 - Železná Ruda (after Menšík 2018, Fig. 2); 6 - Kolvín (after Sklenář 1986, Table I:11); 7-8 - Cáslav (after Čermák 1907, Fig. 2, 4); 9 - Písek (after Fröhlich 1992, Fig. 4:1). Fig. 6-8 unscaled. By T. Kurasiński 

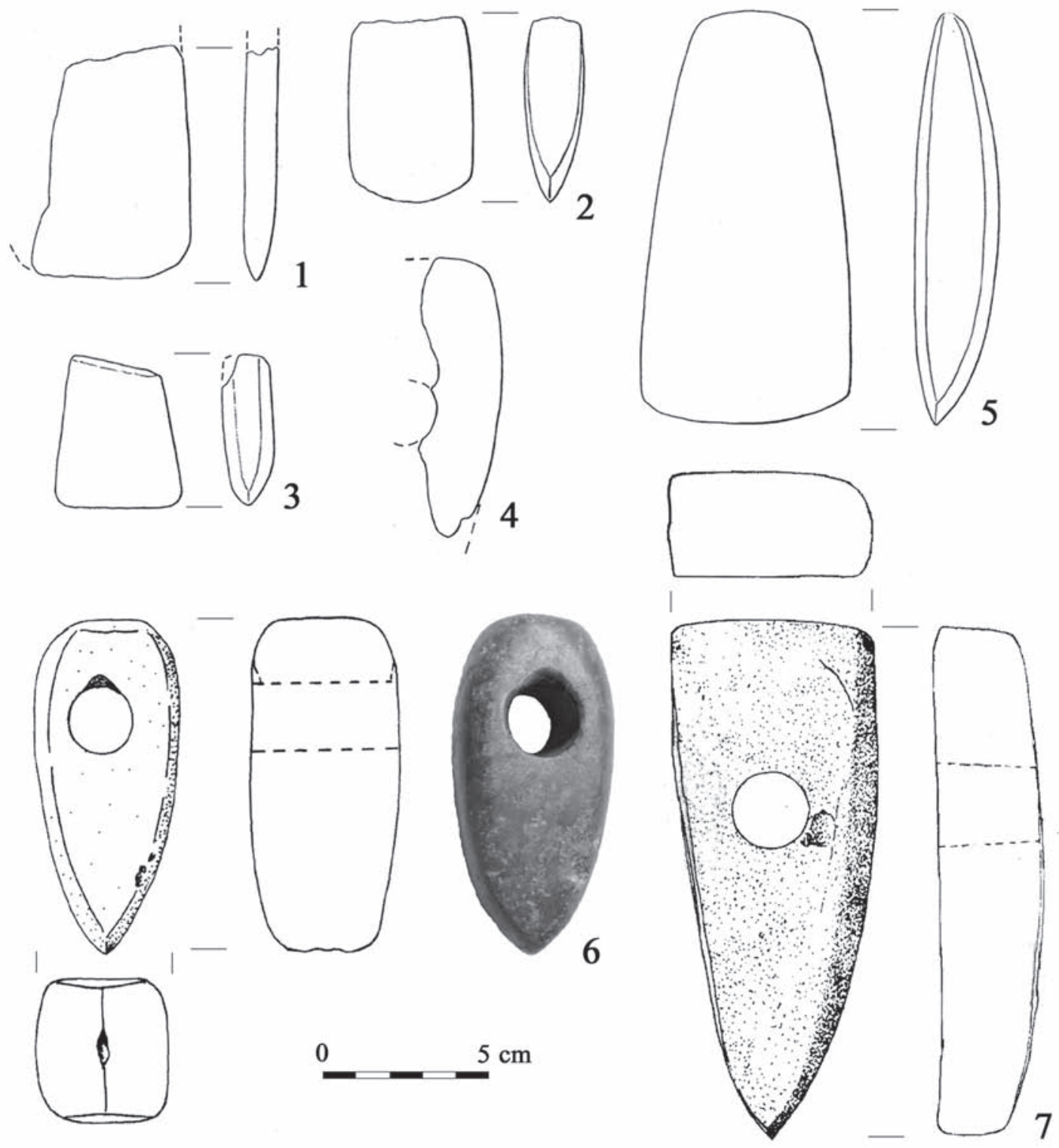

Ryc. 3. Kamienie piorunowe z terenu Moraw (1-5) i Słowacji (6-7): 1-5 - Mikulčice (wg Medunová-Benešová 1997, ryc. 14:1-2, 5-7); 6 - Devin (wg Farkaš, Gregor 2016, ryc. 2); 7 - Lúčnice nad Žitavou (wg Novotný 1991, ryc. 30). Oprac. T. Kurasiński

Fig. 3. Thunderstones from Moravia (1-5) and Slovakia (6-7): 1-5 - Mikulčice (after Medunová-Benešová 1997, Fig. 14:1-2, 5-7); 6 - Devin (after Farkaš, Gregor 2016, Fig. 2); 7 - Lúčnice nad Žitavou (after Novotný 1991, Fig. 30). By T. Kurasiński

235). Kamienie piorunowe stwierdzono także w obrębie późnośredniowiecznych fortyfikacji, przykładowo w Lelekovicach (Unger 1999, 111) i na zamku Tepenec (Kalábek 2001, 118).

$\mathrm{Z}$ ponownym zastosowaniem należy także liczyć się $\mathrm{w}$ przypadku eneolitycznego siekieromłota $\mathrm{z}$ serpentynu odkrytego w bliżej nieokreślonym miejscu na wzgórzu zamkowym w słowackim Devinie (ryc. 3:6) (Farkaš, Gregor 2016, 35, ryc. 2). Siekieromłot z eneolitu znajdował się również za belką więźby dachowej domu nr 156 w miejscowości Lúčnice nad Žitavou (ryc. 3:7) (Novotný 1991).

Bogatą kolekcję zebrano z Niemiec. Kamienny topór pod paleniskiem znaleziono we wczesnosłowiańskiej ziemiance w Tützpatz (Jacobs 1991, 27). Z Meklemburgii znamy kilka innych okazów. Podczas wyburzania domu w Malchow w krokwi dachowej odkryto dobrze zachowany topór (Grünsteinaxt), 

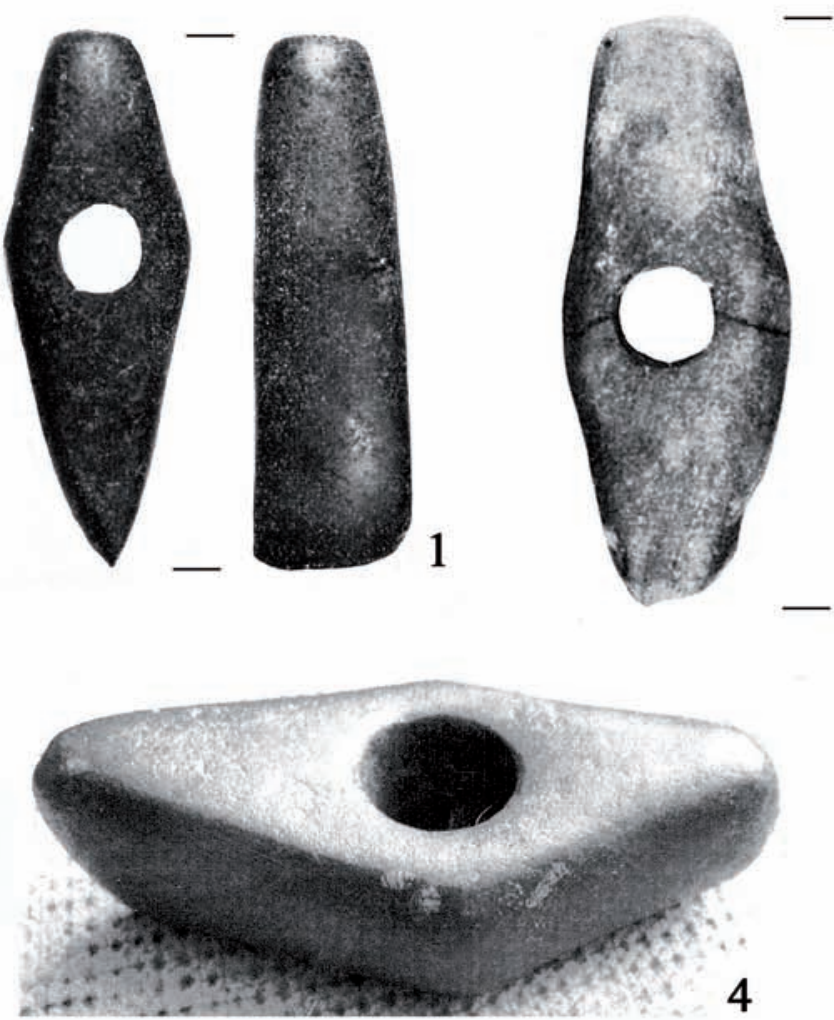
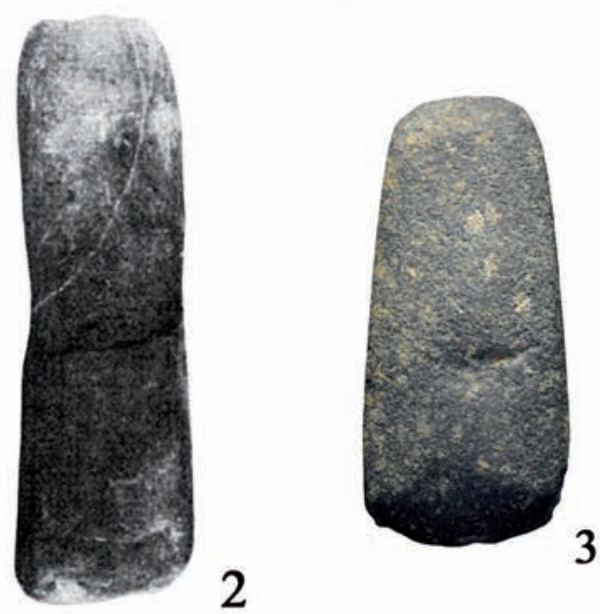

2
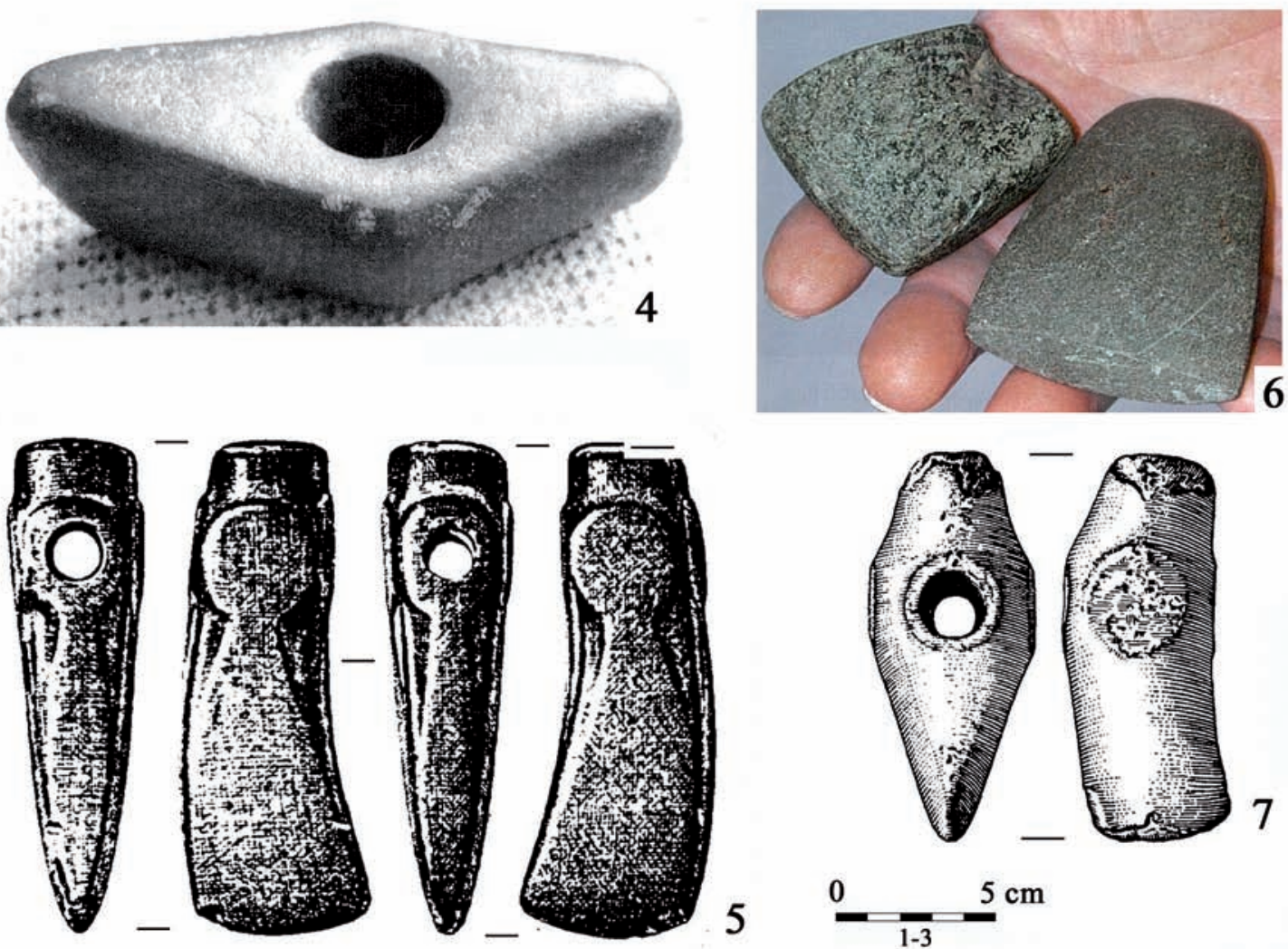

Ryc. 4. Kamienie piorunowe z terenu Niemiec: 1 - Malchow (wg Schoknecht 1978, ryc. 14:a); 2 - Mellenau (wg Schoknecht 1964, ryc. 181:d); 3 - Horst (wg Samariter 2014, ryc. 1); 4 - Schwarz (wg Schoknecht 2005, ryc. 1); 5 - Eimsen (wg Barner 1957, ryc. 3); 6 - Großgoltern (wg Cosack 2004, ryc. na s. 62); 7 - Winzenburg (wg Barner 1957, ryc. 6). Ryc. 1-3 skala przybliżona, pozostałe nieskalowane. Oprac. T. Kurasiński

Fig. 4. Thunderstones from Germany: 1 - Malchow (after Schoknecht 1978, Fig. 14:a); 2 - Mellenau (after Schoknecht 1964, Fig. 181:d); 3 - Horst (after Samariter 2014, Fig. 1); 4 - Schwarz (after Schoknecht 2005, Fig. 1); 5 - Eimsen (after Barner 1957, Fig. 3); 6 - Großgoltern (after Cosack 2004, Fig. on p. 62); 7 - Winzenburg (after Barner 1957,

Fig. 6). Fig. 1-3 approximate scale, others unscaled. By T. Kurasiński

należący do wyrobów kultury grobów jednostkowych (ryc. 4:1) (Schoknecht 1978, 391, ryc. 14:a; HeidelkSchacht 1983, 107, fig. 17:b). Z tą samą jednostką kulturową wiązany jest okaz odkryty w rumowisku w czasie rozbiórki starego pieca w Mellenau. Na jego powierzchni zaobserwowano wyraźne okopcenie (ryc. 4:2) (Schoknecht 1964, 378, ryc. 181:d; HeidelkSchacht1983, 107,fig. 17:a). Duży, staranniewykonany 


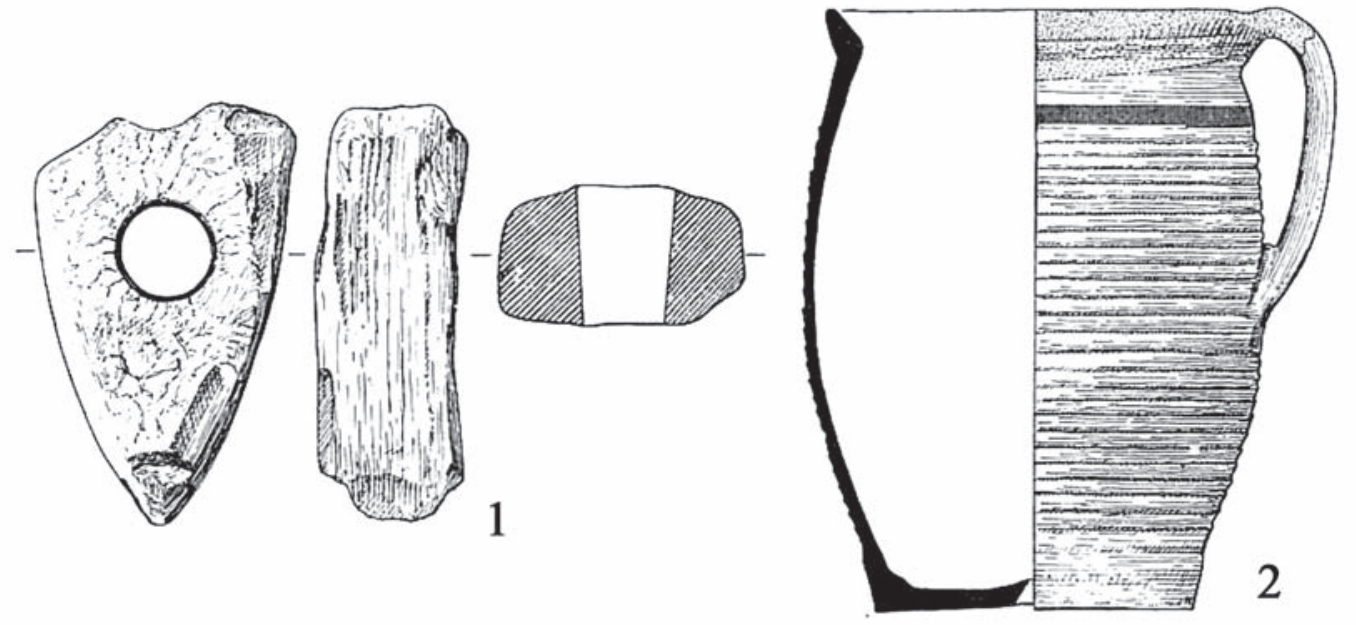

Ryc. 5. Zespół znalezisk z Pockau (Saksonia, Niemcy): 1 - naczynie gliniane; 2 - topór kamienny (wg Geupel 1987, ryc. 1). Ryc. nieskalowana. Oprac. T. Kurasiński

Fig. 5. Collection of finds from Pockau (Saxony, Germany): 1 - clay vessel; 2 - stone axehead (after Geupel 1987, Fig. 1). Fig. unscaled. By T. Kurasiński

egzemplarz z diorytu pochodzi też z Gnoien. Znaleziono go podczas prac rozbiórkowych domu, przy czym dokładna lokalizacja nie jest znana (Heidelk-Schacht 1983, 107). Częściowa rozbiórka pomieszczenia gospodarczego z XIX w. w Horst niedaleko Greifswaldu dostarczyła kolejnego znaleziska. Bazaltowa siekiera neolityczna (kultura pucharów lejkowatych) leżała na belce stropowej przy zachodnim szczycie budynku (ryc. 4:3) (Samariter 2014). W odmiennych okolicznościach pozyskano eneolityczny topór ze Schwarz, reprezentujący kulturę grobów jednostkowych. Został on przekazany przez właściciela, który trzymał go w domu na krośnie (ryc. 4:4) (Schoknecht 2005).

Kamienie piorunowe znane są także $\mathrm{z}$ innych landów. Odnotowano je na średniowiecznych stanowiskach z Dolnej Saksonii. W Brunszwiku na kamienny topór natrafiono wśród materiału ceramicznego $\mathrm{z}$ warstwy przepalonego gruzu z połowy XIII w. (Rötting 1985, 108-112, ryc. 62:a za Demuth 2002, 114). Młodszy kontekst ma okaz z Groß Steinum (dziś część miasta Königslutter am Elm). Podczas prac remontowych domu (o metryce sięgającej przynajmniej 300 lat) w otworze belki podwalinowej (przycieś) odkryto tam wczesnoneolityczny topór kamienny (Demuth 2002). W Emmerm znaleziono dobrze zachowany topór bojowy (kultura ceramiki wstęgowej rytej), który umieszczono w zagłębieniu ceglanego komina, tuż pod kalenicą dachu domu z 1823 r. (Norkus 1959, 219). Również w kominie domu (nr 19) w Eimsen (dziś część miasta Alfeld) podczas prac remontowych znaleziono topór $\mathrm{z}$ wygiętym obuchem (nackengebogenen Axt). Okaz był starannie wypolerowany i pokryty grubą warstwą sadzy (ryc. 4:5) (Barner 1957, 5-6, ryc. 3; 1968, 242, ryc. 15). Z kolei w Apen znaleziono topór kamienny (dioryt?) na krokwi jednego z tamtejszych domów. Wiąże się go z kulturą grobów jednostkowych (Zoller 1981, 286). Warto także zwrócić uwagę na dwie siekiery znalezione na polu w pobliżu Großgoltern w rejonie Hanoweru. Miały one płasko ścięte i wygładzone ostrza, co wskazuje na ich wtórne wykorzystanie w czasach nowożytnych, gdyż takie zjawisko nigdy nie było obserwowane w neolicie (ryc. 4:6) (Cosack 2004). Bardzo ciekawym przykładem wtórnego użycia narzędzi pradziejowych jest umieszczanie ich w murach miejskich, jak to miało miejsce w Northeim (Mildenberger 1961, 5; Sklenáŕ 1999, 29). Na uwagę zasługuje wreszcie kamienny młot odkryty przy źródle Apenteich (Apetenquelle) w Winzenburgu wśród innych pradziejowych wyrobów (ryc. 4:7) (Barner 1957, $7-8$, ryc. 6 , tu dalsze przykłady znalezisk dolnosaksońskich). Odnotowano także obecność kamiennej siekiery w grobie nr 16 na cmentarzysku we Fließau, przy czym na temat tego znaleziska brak jest dokładnych danych (Pollex 2010, 200, 525).

Interesujące nas przedmioty znane są też z Saksonii. W Pockau pod podłogą sieni domu wzniesionego między 1650 a 1700 r. znaleziono naprawiany albo przerabiany kamienny topór (ryc. 5:1). Obok zalegało naczynie datowane na 2. połowę XVII w. (ryc. 5:2), co potwierdza złożenie całego depozytu w czasie budowy domu (Geupel 1987, 2-3, ryc. 1). Kamienny to- 
pór również został zakopany w sieni domu z około 1700 r. w Wiesa (ryc. 6:1) (Geupel 1987, 3-4, ryc. 2). Podczas rozbiórki zachodniej ściany szczytowej XVIwiecznego domu we Freibergu znaleziono kolejny topór. Ze względu na charakterystyczną formę został on datowany na późną epokę brązu lub wczesną epokę żelaza (Geupel 1987, 4, tabl. 1:c). Jeszcze jeden kamienny egzemplarz stwierdzono na belce dachowej stodoły w Taltitz (Geupel 1987, 4, tabl. 1:d). Wskazać można także na wyroby pradziejowe z rejonu Rudaw i Vogtlandu, niezwiązane bezpośrednio ze średniowiecznymi i nowożytnymi budynkami, ale zalegające w ich niedalekim sąsiedztwie (zob. Geupel 1987, 4).

W Obervorschütz (północna Hesja) natrafiono na dwa kamienne lemiesze neolityczne (Pflugschar). Jeden $\mathrm{z}$ nich zamurowano w ścianie XVIII-wiecznego domu. Znajdował się on w zagłębieniu dostosowanym do swojego kształtu, z krawędzią tnącą ku górze. Drugi wydobyto z podstawy komina w piwnicy budynku wzniesionego w 1905 r. (Heintel 1961). Wiele przykładów z tej części Niemiec przytacza G. Mildenberger
(1961, 5; zob. też mapę rozprzestrzenienia w Ramminger 2007, ryc. 2). Na przedmioty te natrafiano zarówno w budynkach mieszkalnych, jak i zabudowaniach gospodarczych (głównie w ścianach, piwnicach i kominach oraz pod podłogami i w obrębie dachu), np. w Frielendorf, Fritzlar, Großseelheim, Kammerbach, Leimbach, Loshausen i Treysa. Co ciekawe, okazy z Reinsfeld i Schnellrode znaleziono odpowiednio przy przepuście wody i w korycie strumienia (Mildenberger 1961, 5). Wymienić należy ponadto siekierę ze spiczastym obuchem (spitznackiges Beil) odkrytą pod jedną z przypór kościoła w Alsfeld (Ramminger 2007, 11).

Wiele okazów znanych jest z Turyngii, zwłaszcza z okolic miast Gotha i Gera (m.in. Eberstädt, Langenberg, Sonneborn). Pochodziły one z dawnych zabudowań, gdzie najczęściej trzymano je w przestrzeni dachowej i wmurowywano w ściany (Auerbach 1936, 35; Kaufmann 1936, 32-33).

Dwa neolityczne wyroby z amfibolitu stanowią efekt badań zamku Ketzelburg w Haibach (Bawa-
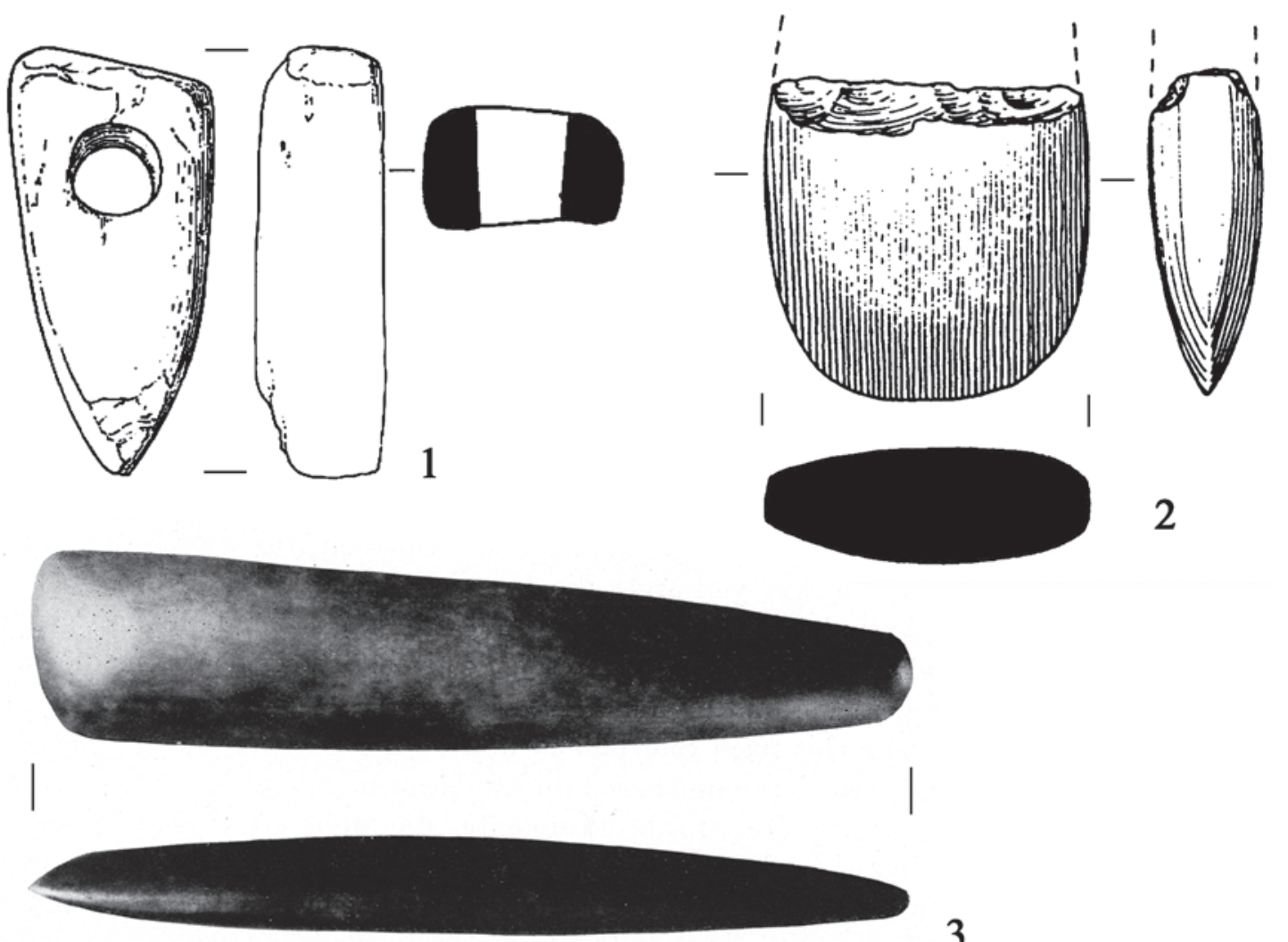

Ryc. 6. Kamienie piorunowe z terenu Niemiec: 1 - Wiesa (wg Geupel 1987, ryc. 2); 2 - Xanten-St. Victor (wg Siegmund 1998, tabl. 228); 3 - Hedeby (wg Paulsen 1939, ryc. 115). Ryc. nieskalowane. Oprac. T. Kurasiński Fig. 6. Thunderstones from Germany: 1 - Wiesa (after Geupel 1987, Fig. 2); 2 - Xanten-St. Victor (after Siegmund 1998, Table 228); 3 - Hedeby (after Paulsen 1939, Fig. 115). Fig. unscaled. By T. Kurasiński 

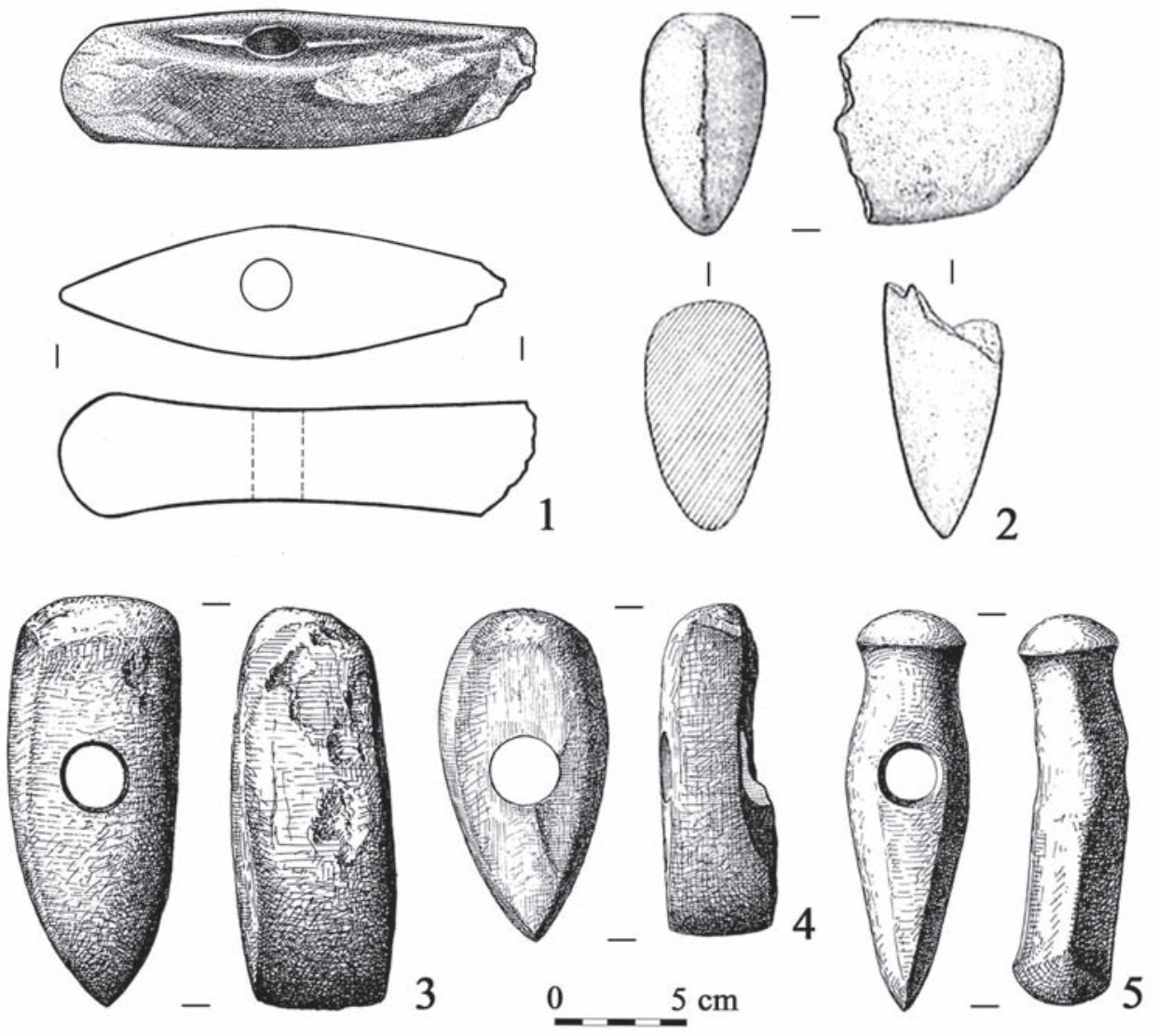

Ryc. 7. Kamienie piorunowe z terenu Austrii: 1 - Wels (wg Riess 1981, ryc. 1-3); 2 -Zitternberg bei Gars am Kamp (wg Maurer 2012, ryc. 1); 3 - Obermödlham (wg Hell 1962, ryc. 2); 4 - Ibm (wg Hell 1959, ryc. 2); 5 - Enns (wg Hell 1959, ryc. 1). Oprac. T. Kurasiński

Fig. 7. Thunderstones from Austria: 1 - Wels (after Riess 1981, Fig. 1-3); 2 - Zitternberg bei Gars am Kamp (after Maurer 2012, Fig. 1); 3 - Obermödlham (after Hell 1962, Fig. 2); 4 - Ibm (after Hell 1959, Fig. 2); 5 - Enns (after Hell 1959, Fig. 1). By T. Kurasiński

ria). Pierwszy to zachowane we fragmencie narzędzie w kształcie kopyta szewskiego (Schuhleistenkeils), które mogło służyć jako motyka, dłuto lub siekiera. Zabytek został znaleziony pod fundamentem ściany wieży mieszkalnej. Drugim jest umieszczony w wypełnisku muru bramnego nieudany topór (Steinbeilrohling) (Roth 2006) ${ }^{10}$. Obydwa przedmioty na wzgórzu zamkowym pojawiły w 2. połowie XII w. (Rosmanitz 2006, 58).

Kilka okazów pochodzi z Nadrenii Północnej Westfalii. W ruinach klasztoru cysterek Martha Hof w Bonn znaleziono dużą siekierę z jadeitu. Pierwotnie

10 Z samego miasta znany jest jeszcze jeden kamień piorunowy, który znajdował się w belce więźby dachowej domu (Roth 2006, 111). W pełni zachowany klin pochodzi także z sąsiedniej miejscowości Hösbach (Roth 2006, 107). umieszczono ją na dachu spichlerza (Evans 1897, 58). W ratuszu z Höxter nad Wezerą odkryto topór z amfibolitu w wypełnisku szybu kominowego z połowy XIII w. (König 1994, 190, ryc. 35 za Demuth 2002, 114). Z Nadrenii pochodzi też połowa kamiennej siekiery odkrytej w grobie P 58 na cmentarzysku merowińskim w Xanten-St. Victor. Pochówek należy do fazy datowanej na lata 555-570 (ryc. 6:2) (Siegmund 1998, 448, tabl. 228).

Kilka egzemplarzy stwierdzono w Haddeby (Busdorf, Schleswig-Holstein) na terenie wczesnośredniowiecznego zespołu osadniczego Hedeby (Haithabu). Siekierę kamienną znaleziono w obrębie dużej hali (palenisko). Zabytek nie jest wyrobem miejscowym, ma pochodzenie zachodnioeuropejskie (ryc. 6:3) (Paulsen 1939, 190, ryc. 115). Inny importowany wczesnoneolityczny topór typu łodziowego (Bootaxt) pochodzi z półkolistego wału. Zachowany jest on 
fragmentarycznie (Schultrich 2018, 121, 389). Topór eklogitu z północnych Włoch znaleziono również w rejonie portowym (Klassen 2004, 83 za Klimscha, Nowak 2009, 37).

Dodajmy jeszcze, iż w katedrze w Halberstadt (Saksonia-Anhalt) topór neolityczny został zawieszony na łańcuchu pierwszej kolumny między nawami główną a lewą (Vařeka 1991, 118).

Dalsze przykłady pradziejowych wyrobów umieszczanych głównie na belkach dachowych, pod progami, w fundamentach i kominach budynków z XVIII i XIX w. z terenu północnych Niemiec podaje M. Bartels (1893).

Wiele kamieni piorunowych mamy potwierdzonych w Austrii. Jednym z nich jest neolityczny (kultura ceramiki sznurowej), nieco uszkodzony, topór z serpentynu znaleziony w Wels, w murze dawnego budynku poszpitalnego (Stelzhamerstraße 6) przy okazji prac rozbiórkowych (ryc. 7:1). Zamurowano go tam najprawdopodobniej w latach 1583-1585, choć mogło do tego dojść jeszcze w XV stuleciu (Riess 1981). Inne znalezisko to zachowana krawędź tnąca siekiery z polerowanego lokalnego serpentynu z Zitternbergu bei Gars am Kamp. Stan zachowania zabytku nie pozwala na jego bliższą rekonstrukcję i typologiczne przyporządkowanie, aczkolwiek neolityczne pochodzenie jest najbardziej prawdopodobne (ryc. 7:2). Przedmiot złożono pod drewnianą podłogą domu z około $1900 \mathrm{r}$. (Maurer 2012). Z kolei pod wschodnią stroną więźby dachowej domu w Klein-Hummelberg natrafiono swobodnie wiszący pradziejowy siekieromłot również wykonany z serpentynu (Mitmannsgruber 1962). $\mathrm{Z}$ tego samego surowca wykonano neolityczny topór z Obermödlham (ryc. 7:3). Odkryto go przy burzeniu ściany cokołowej spichlerza sprzed 200-300 lat. Zapewne przedmiot został włożony w kamienny fundament budowli, o czym świadczą obecne na nim pozostałości zaprawy (Hell 1962, 30-32, ryc. 2; 1964, 301). Kolejny topór neolityczny wykonany z hornblendy pozyskano podczas usuwania zabudowań średniowiecznego zamku w Ibm (ryc. 7:4). Przypuszczalnie przedmiot ten został wmurowany w budynek (Hell 1959, 96-97, ryc. 2; 1964, 301). Wspomnieć należy także o młocie-toporze (serpentyn) z Enns, pierwotnie również umieszczonym w ścianie domu, który zapewne uległ pożarowi. Wskazują na to przebarwienia i ślady zaprawy widoczne na zabytku (Hell 1959, 96, ryc. 1) (ryc. 7:5). Liczne przykłady z rejonu Górnej Austrii i Salzburga (m. in. z Edt, Gramastetten, Kefermarkt, Katzdorf, Münzbach, Naarn, Schwertberg, Waldkirchen am Wessen i Waldneukirchen) oma- wia J. Reitinger (1976). Wśród nich są egzemplarze umieszczane na strychach, zamurowywane w ściany, składane pod podłogę i przechowywane w domach (ryc. 8).

Dość liczny zbiór kamieni piorunowych zebrano i opublikowano również z terenu Holandii. Narzędzie w kształcie kopyta szewskiego (Schuhleistenkeil) z wczesnego neolitu jeszcze do niedawna wisiało na gwoździu pod strzechą jednego z domostw w Staphorst (ryc. 9:1). Przedmiot ten był w posiadaniu tej samej rodziny od 1880 r. (Beuker 1997, 20; Eijk van 2008, 171). Kilka okazów znajduje się w zbiorach Drents Museum w Assen. Jednym z nich jest półprodukt dużego kamiennego topora-młota znalezionego w Westenesch w chlewie (ryc. 9:3) (Beuker 1997, 23; Eijk van 2008, 171). Natomiast z Vijlen znany jest okaz wiązany z kulturą ceramiki wstęgowej rytej, który jeszcze do niedawna służył jako środek w leczeniu zwierząt (ryc. 9:2) (Verhart 2016, 8, ryc. 6). Kilka okazów znaleziono w kontekście wcześniejszym. Dwa topory pozyskano w czasie eksploracji średniowiecznej drogi brukowej w pobliżu Bronneger (Beukert 1997, 24; Eijk van 2008, 171; w pracach tych inne przykłady). Podczas badań fundamentów późnośredniowiecznego zamku Groesbeek w gruzowisku jednego z pomieszczeń znaleziono neolityczną kamienną siekierę (kwarcyt). Przedmiot wykazuje duże ubytki ostrza (ryc. 9:4) (Tuijn 1992). Kolejne znalezisko, prawdopodobnie również z późnego średniowiecza, pochodzi z Nijmegen, gdzie podczas pogłębiania jednej $\mathrm{z}$ piwnic $\mathrm{w}$ pobliżu pieca znaleziono kamienny topór (Eijk van 2007, 214). Kilka przykładów kamiennych toporów i siekier oraz innych obiektów pradziejowych, występujących w znacznie młodszym, choć trudnym do jednoznacznego określenia, kontekście chronologicznym zebrano w północnej części prowincji Groningen (Feiken, Knol 2006). Odosobnionym znaleziskiem jest połówka siekiery z cmentarzyska merowińskiego w Meerveldhoven (Eijk van 2007, 213).

Dysponujemy wieloma znaleziskami północnoeuropejskimi. Wśród znalezisk skandynawskich (Dania, Norwegia, Szwecja) należy wspomnieć o bogatym zbiorze pradziejowych wyrobów ze średniowiecznego Lundu, w większości ze środkowego neolitu, wśród których znaczny odsetek stanowiły kamienne topory i siekiery różnych typów (Carelli 1996, 153-155; Carelli 1997, 393-395). Nie wszystkie okazy mają dokładnie określoną lokalizację, aczkolwiek jeden z nich odkryto wśród kamieni progowych domu datowanego na XV-XVI w. (Carelli 1996, 155, 

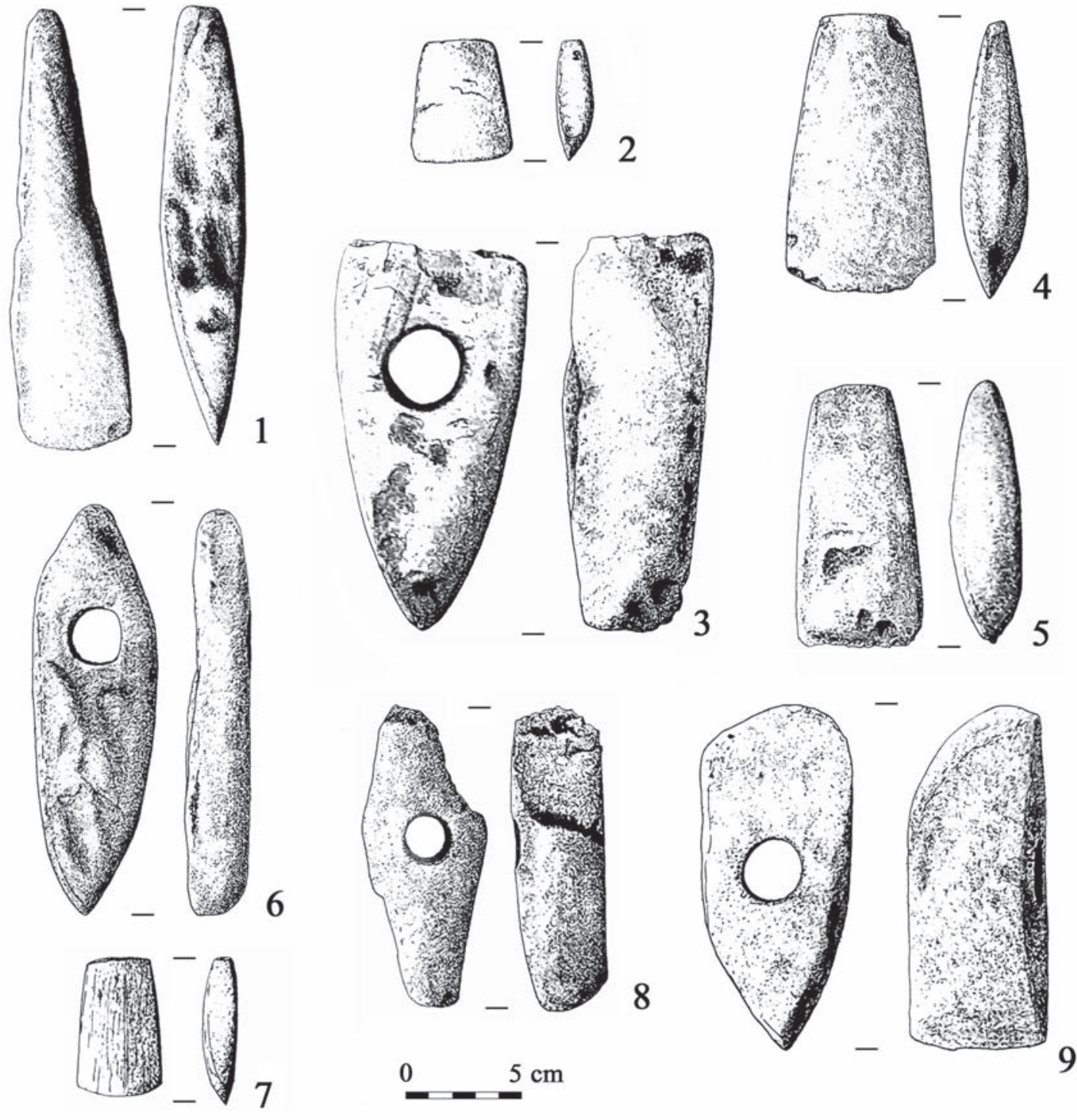

Ryc. 8. Kamienie piorunowe z terenu Austrii: 1 - Edt (wg Reitinger 1976, ryc. 3:1); 2 - Gramastetten (wg Reitinger 1976, ryc. 1:3); 3 - Kefermarkt (wg Reitinger 1976, ryc. 1:1); 4 - Katzdorf (wg Reitinger 1976, ryc. 1:6); 5 - Münzbach (wg Reitinger 1976, ryc. 2:3); 6 - Naarn (wg Reitinger 1976, ryc. 1:2); 7 - Schwertberg (wg Reitinger 1976, ryc. 1:5); 8 - Waldkirchen am Wessen (wg Reitinger 1976, ryc. 2:4); 9 - Waldneukirchen (wg Reitinger 1976, ryc. 2:1). Oprac. T. Kurasiński

Fig. 8. Thunderstones from Austria: 1 - Edt (after Reitinger 1976, Fig. 3:1); 2 - Gramastetten (after Reitinger 1976, Fig. 1:3); 3 - Kefermarkt (after Reitinger 1976, Fig. 1:1); 4 - Katzdorf (after Reitinger 1976, Fig. 1:6);

5 - Münzbach (after Reitinger 1976, Fig. 2:3); 6 - Naarn (after Reitinger 1976, Fig. 1:2); 7 - Schwertberg (after Reitinger 1976, Fig. 1:5); 8 - Waldkirchen am Wessen (after Reitinger 1976, Fig. 2:4); 9 - Waldneukirchen (after Reitinger 1976, Fig. 2:1). By T. Kurasiński

168, ryc. 3; Carelli 1997, 396, ryc. 3). Ewidentnie średniowieczny kontekst mają m.in. kamienne topory odkryte na innych stanowiskach szwedzkich - w Malmö, i Söderköping oraz norweskich - w Bergen i Oslo (Carelli 1996, 163; Carelli 1997, 411-412). Cztery topory pochodzą z Önnerup niedaleko Lundu. Wszystkie były wtórnie związane z wczesnośredniowieczną osadą, a jeden $\mathrm{z}$ nich odkryto $\mathrm{w}$ dołku posłupowym jednego ze słupów podtrzymujących dach domu typu Trelleborg z XI-XII w. (Carelli 1996, 163, ryc. 7; Carelli 1997, 413, ryc. 8). Na kilka zabytków natrafiono w Hyllie (Szwecja). We wnętrzu domu, bezpośrednio pod podłogą, natrafiono na czworoboczny topór wraz z monetą z 1525 r. Dom jest jednak znacznie 

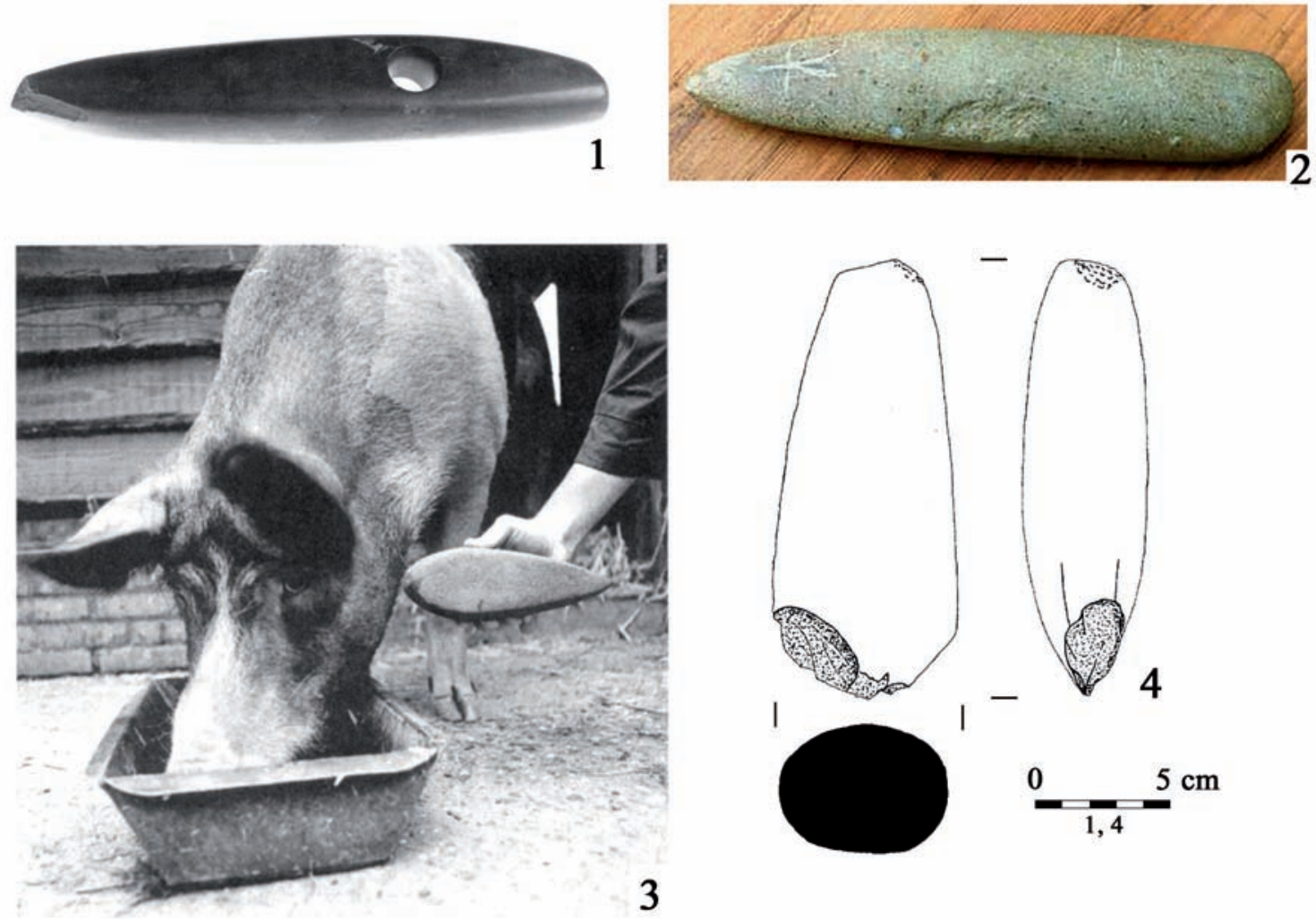

3

Ryc. 9. Kamienie piorunowe z terenu Holandii: 1 - Staphorst (wg Beuker 1997, ryc. na s. 20); 2 - Vijlen (wg Verhart 2016, ryc. 6); 3 - Westenesch (wg Beuker 1997, ryc. na s. 22); 4 - Groesbeek (wg Tuijn 1992, ryc. na s. 41). Ryc. 2-3 nieskalowane. Oprac. T. Kurasiński

Fig. 9. Thunderstones from the Netherlands: 1 - Staphorst (after Beuker 1997, Fig. on p. 20); 2 - Vijlen (after Verhart 2016, Fig. 6); 3 - Westenesch (after Beuker 1997, Fig. on p. 22); 4 - Groesbeek (after Tuijn 1992,

Fig. on p. 41). Fig. 2-3 unscaled. By T. Kurasiński

starszy - pochodzi z XIV w. Z pobliskiej studni (z późnego średniowiecza lub nieco młodszej) wydobyto zaś kolejny okaz (Carelli 1996, 163; Carelli 1997, 412). Polerowana siekiera z serpentynu(?) znaleziona w norweskim Trondheim została tam sprowadzona i najprawdopodobniej zgubiona pod koniec okresu wikińskiego lub nieco później (ryc. 10:1) (Birgisdottir 2001). We Fretheim w zachodniej Norwegii z pozostałości fundamentów starego budynku warzelni (norw. ildhus) wydobyto kamienny topór z wygrawerowaną datą roczną „1617” (ryc. 10:2) (Lødøen 1993).

W zupełnie innych okolicznościach został pozyskany połowicznie zachowany późnoneolityczny topór z Räppe (Smalandia, Szwecja) (ryc. 10:3). Wszedł on bowiem w skład skarbu 385 monet średniowiecznych, zdeponowanego w 2. połowy XIII w. w neolitycznej kamiennej skrzyni grobowej, w której - w epoce brązu - doszło do wtórnego pochówku. Grób nie zawierał szczątków ludzkich. Intencjonalnie złożony topór znajdował się bezpośrednio pod stosem monet, w dole wykopanym w kamiennym wypełnisku komory (w jej południowym krańcu), a następnie zasypanym (ryc. 12) (Kjellmark, Thordeman 1939).

Ze środkowej Norwegii znane są również zabytki pozyskane z młodszego kontekstu chronologicznego. Kamienny topór odkryto w miejscu starego budynku na farmie Skjelbrei w Skogn (ryc. 10:4). Na kolejny okaz natrafiono na farmie Nordli w Stjørdal w czasie prac porządkowych po rozbiórce budynku gospodarczego. Topór znajdował się w ścianie między szopą a chlewem (Kalseth 2000, 30). Zebrano też wiele okazów z zachodnionorweskich terenów wiejskich z XIX i początku XX w. (Søyland 2007, 37-40). Liczne znaleziska „etnograficzne” ze Szwecji zaprezentował N.E. Hammarstedt (1920, 14-17), o których będzie mowa w dalszej części pracy (ryc. 10:5-12).

Przykład wtórnego użycia kamiennej siekiery mamy w Lynderup Sogn (Dania). Znaleziono ją na 

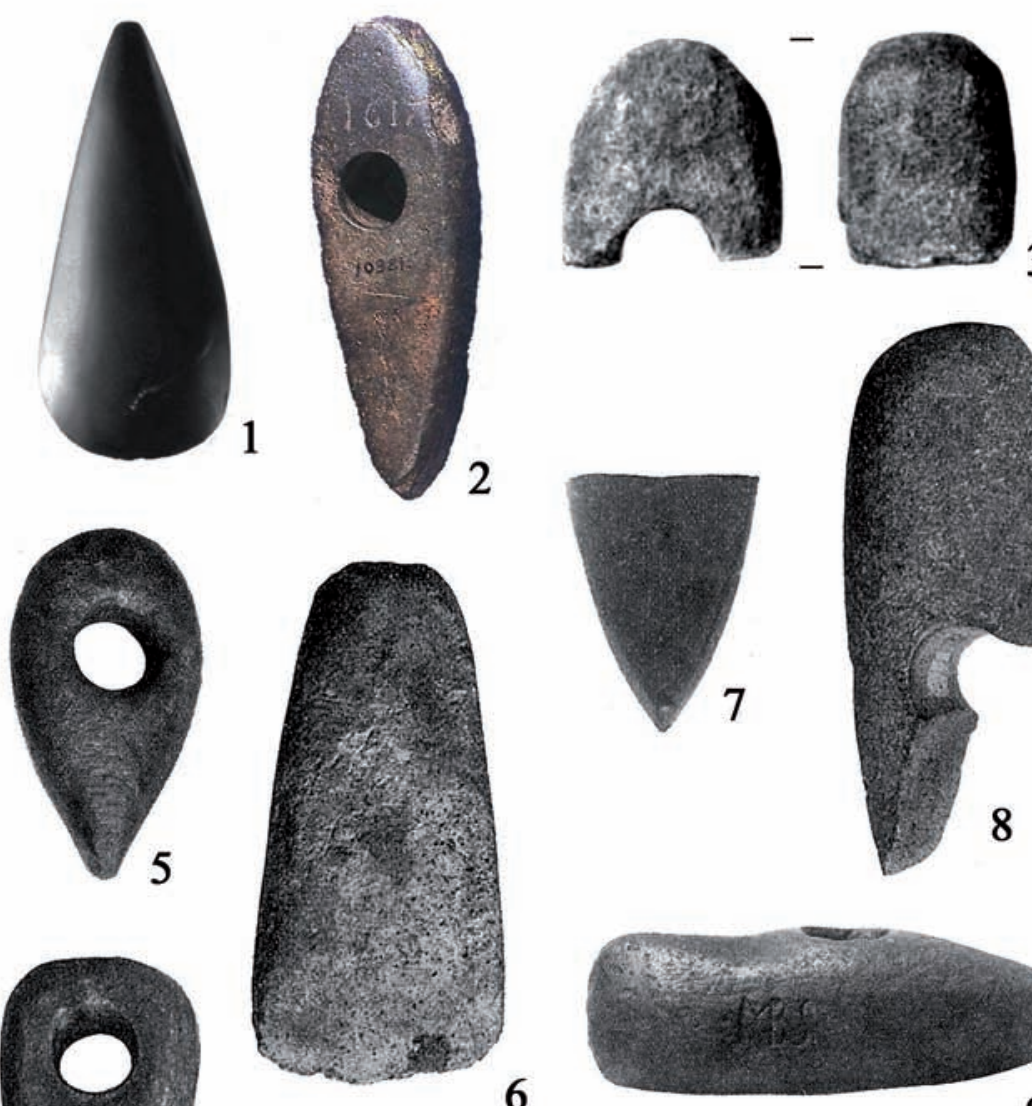

3

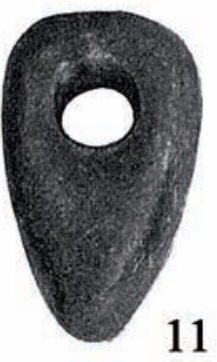

6
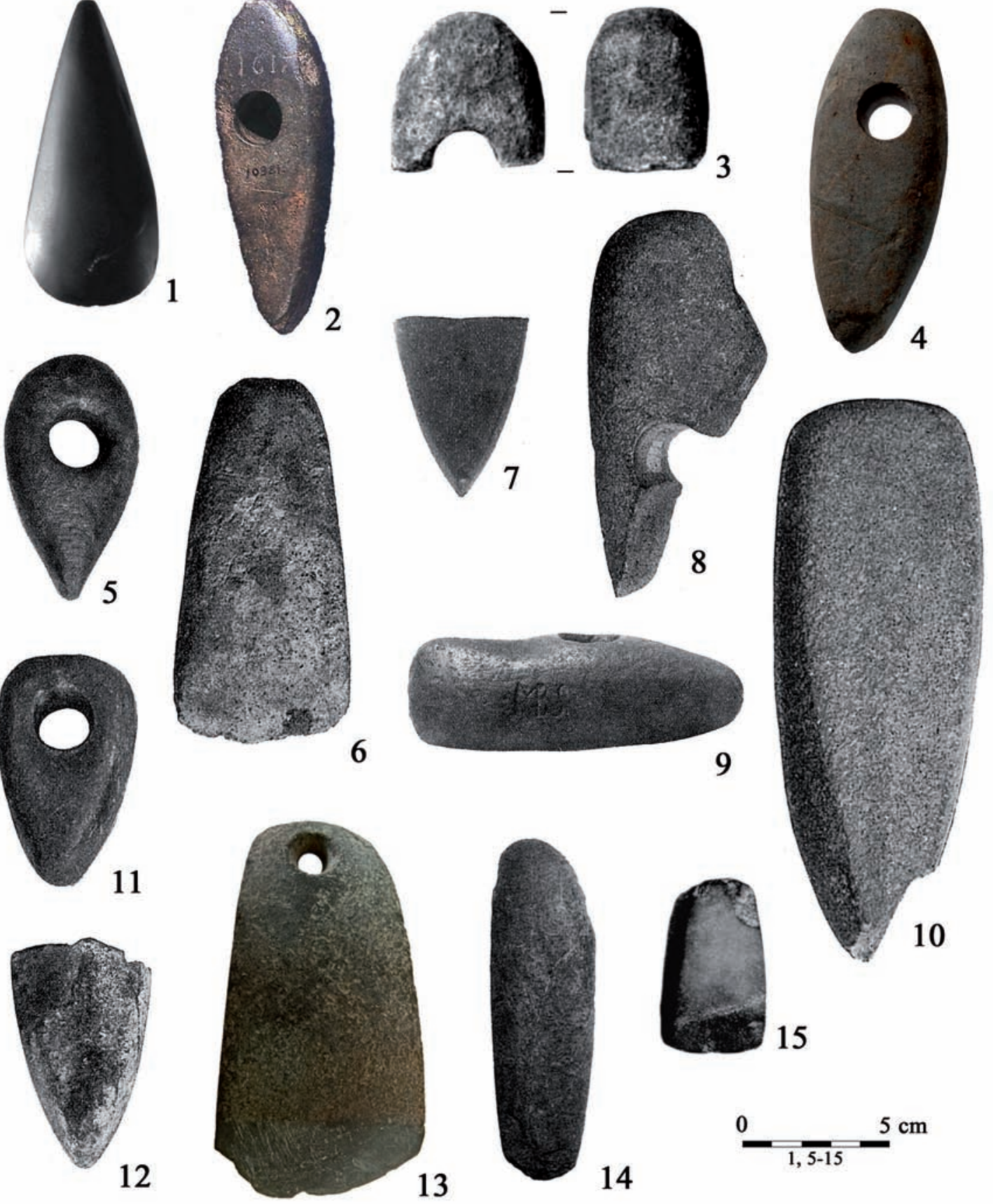

15

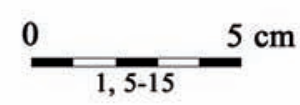

14

Ryc. 10. Kamienie piorunowe ze Skandynawii: 1 - Trondheim (wg Birgisdottir 2001, ryc. na s. 49); 2 - Fretheim (wg Lødøen 1993, ryc. na s. 32); 3 - Räppe (wg Kjellmark, Thordeman 1939, ryc. 4); 4 - Skogn (wg Kalseth 2000 , ryc. na s. 29); 5 - Lilla Ånhult (wg Hammarstedt 1920, ryc. 11); 6 - Uppsala (wg Hammarstedt 1920, ryc. 13); 7 - Skepptuna

(wg Hammarstedt 1920, ryc. 14); 8 - Ökna (wg Hammarstedt 1920, ryc. 19); 9 - Södra Vi (wg Hammarstedt 1920, ryc. 22); 10 - Boda (wg Hammarstedt 1920, ryc. 21); 11 - Huskölen (wg Hammarstedt 1920, ryc. 12); 12 - Entsebo

(wg Hammarstedt 1920, ryc. 18); 13 - Hønborggård (wg Søvsø et al. 2016, ryc. 6); 14 - Avaldsnes (wg Thäte,

Hemdorff 2009, ryc. 2); 15 - Terum (wg Samdal 2000, ryc. 5.2.2c:B). Ryc. 2-4 nieskalowane. Oprac. T. Kurasiński

Fig. 10. Thunderstones from Scandinavia: 1 - Trondheim (after Birgisdottir 2001, Fig. on p. 49); 2 - Fretheim (after Lødøen 1993, Fig. on p. 32); 3 - Räppe (after Kjellmark, Thordeman 1939, Fig. 4); 4 - Skogn (after Kalseth 2000 ,

Fig. on p. 29); 5 - Lilla Ånhult (after Hammarstedt 1920, Fig. 11); 6 - Uppsala (after Hammarstedt 1920, Fig. 13);

7 - Skepptuna (after Hammarstedt 1920, Fig. 14); 8 - Ökna (after Hammarstedt 1920, Fig. 19); 9 - Södra Vi (after Hammarstedt 1920, Fig. 22); 10 - Boda (after Hammarstedt 1920, Fig. 21); 11 - Huskölen (after Hammarstedt 1920, Fig. 12); 12 - Entsebo (after Hammarstedt 1920, Fig. 18); 13 - Hønborggård (after Søvsø et al. 2016, Fig. 6); 14 - Avaldsnes (after Thäte, Hemdorff 2009, Fig. 2); 15 - Terum (after Samdal 2000, Fig. 5.2.2c:B). Fig. 2-4 unscaled. By T. Kurasiński 

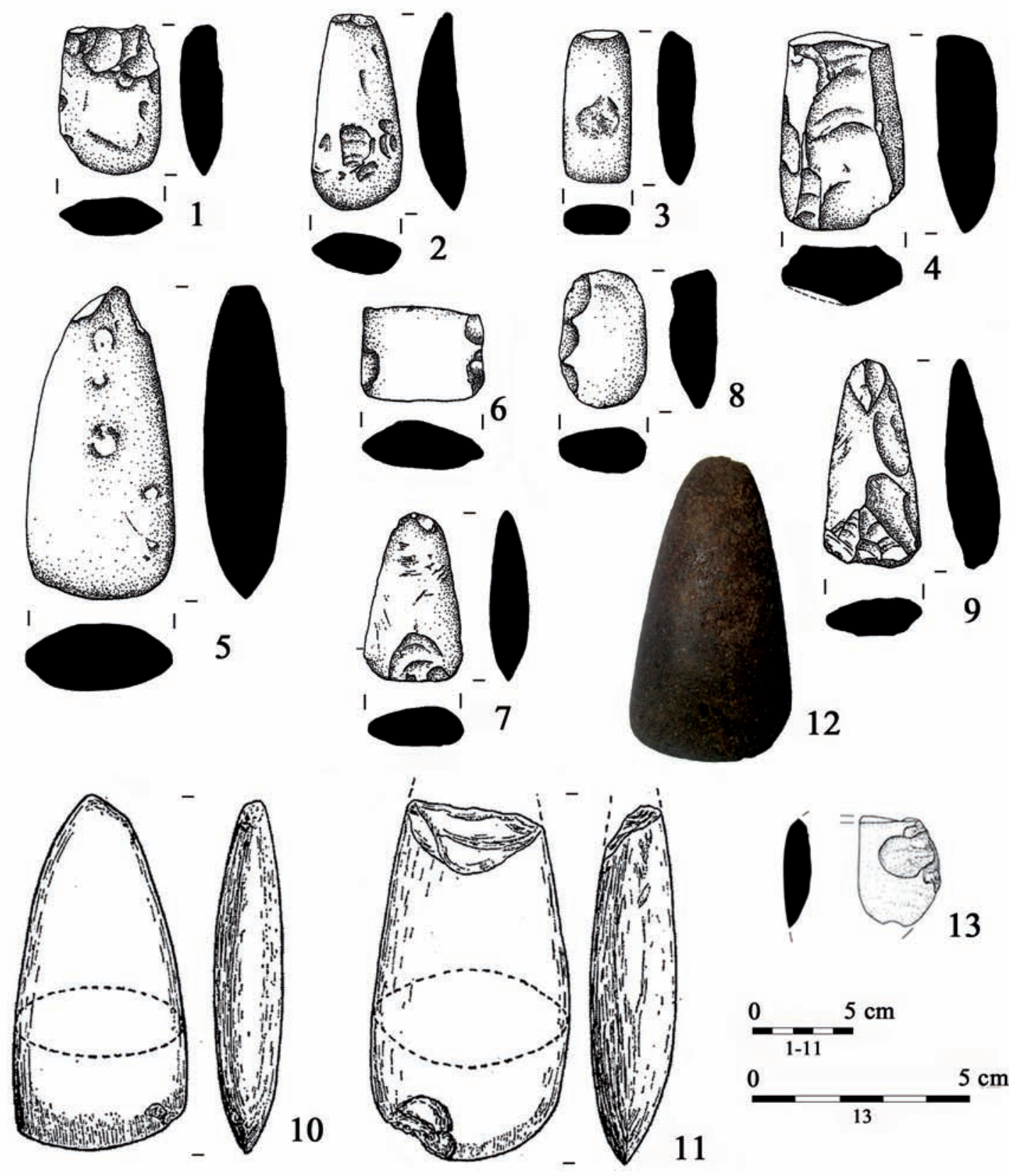

10

Ryc. 11. Kamienie piorunowe z terenu Irlandii (1-12) i Wielkiej Brytanii (13): 1-9 - Deer Park Farms (wg O'Sullivan 2017-2018, ryc. 2); 10-11 - Killamoat Upper (wg Rynne 1964-1965, ryc. 1); 12 - Cloonagun (wg Dowd 2018, ryc. 8); 13 - Silverdale (wg Elsworth, Boughton 2016, ryc. 1). Ryc. 12 nieskalowana. Oprac. T. Kurasiński

Fig. 11. Thunderstones from Ireland (1-12) and Great Britain (13): 1-9 - Deer Park Farms (after O'Sullivan 2017-2018,

Fig. 2); 10-11 - Killamoat Upper (after Rynne 1964-1965, Fig. 1); 12 - Cloonagun (after Dowd 2018, Fig. 8); 13 - Silverdale (after Elsworth, Boughton 2016, Fig. 1). Fig. 12 unscaled. By T. Kurasiński

terenie dworu Lynderupgaard, w miejscu, w którym badania wykopaliskowe ujawniły pozostałości kamiennego budynku z późnego średniowiecza, będącego własnością biskupią. Okaz ten, przynależny do kultury pucharów lejkowatych, zalegał pod progiem. $\mathrm{W}$ takim samym położeniu (próg) znajdowała się perforowana siekiera (kultura ceramiki sznurowej) pochodząca z Hønborggård w parafii Folding Sogn (Dania) (ryc. 10:13). Zdeponowowaną ją tam w XVIII lub XIX w. (Søvsø et al. 2016, 66, ryc. 6).

$\mathrm{Na}$ terenie Norwegii znane są ponadto archaika kamienne pozyskane z cmentarzysk. W Avaldsnes na wyspie Karmøy mezolityczną kamienną siekierę znaleziono w wyrabowanym w połowie XIX w. grobie 
wikińskim (przypuszczalnie kobiecym), powstałym w miejscu znacznie starszego pochówka, przypuszczalnie z okresu przedrzymskiego (ryc. 10:14). Towarzyszyły mu paciorki szklane (Thäte, Hemdorff 2009; Søyland 2017, 51, 294, ryc. 12). Związek z dwoma grobami łodziowymi datowanymi na okres wikiński wykazują pradziejowe siekiery z cmentarzyska w Gulli (Gjerpe 2005, 18, 60, 95). Kolejnych siekier dostarczyły badania wikińskich cmentarzysk w Strand, Terum i Stette. Dwie pierwsze siekiery wykonano z zieleńca, trzecią z oliwinu (ryc. 10:15) (Samdal 2000, 52, 58, 143, 154, 159, 186, ryc. 5.2.2c:B; Søyland 2017, 54, 248, ryc. 15, 18-19). Warto też wspomnieć o starszym grobie (V w.) - podwójnym (dorosła kobieta i dziecko) - z Kvåle, zawierającym siekierę $\mathrm{z}$ diabazu, a także m.in. okrągłe kamyki, ułamek chalcedonu, mikę i kryształ górski (Samdal 2000, 52-53, 103, 163, 176, 186, ryc. 7.2a:A; Søyland 2017, 21-22, 50,184 , ryc. $8-11$ ).

Neolityczne wyroby kamienne pochodzą z licznych stanowisk osadniczych $\mathrm{z}$ wczesnego średniowiecza na terenie Irlandii. Przykładowo, zbiór złożony z 18 siekier, cioseł i dłut pochodzi z nawarstwień obronnej osady (rath) w Deer Park Farms (ryc. 11:1-9). W większości odkryto je w związku z zabudowaniami. Na jeden $z$ toporów natrafiono w warstwie zawierającej węgle drzewne i fragmenty gałązek, interpretowanej jako zawalisko dachu, co może wskazywać, że przedmiot zatknięty był w strzechę (O'Sullivan 2017-2018, 115, ryc. 2). W innym umocnionym miejscu (cashel), w Ballynavenooragh kamienny topór zlokalizowano na bruku wewnątrz jednego $\mathrm{z}$ dwóch połączonych ze sobą domostw (O'Sullivan 2017-2018, 115 , tu inne przykłady z wczesnego średniowiecza).

Można także wskazać na znaleziska z młodszych obiektów. Topór z porfiru (porphyry of Lambay) znaleziono w ścianie starego domu podczas jego rozbiórki w Maynooth, natomiast w Ballintogher na siekierę natrafiono w ścianie szopy (Penney 1976, 70). Dalsze przykłady to dwie wypolerowane kamienne siekiery z Killamoat Upper: jedną odkryto pod kamiennym progiem głównego wejścia do domu, a drugą w niszy ściany pomieszczenia gospodarczego (ryc. 11:10-11) (Rynne 1964-1965). Do listy tej dodać można jeszcze dwa kamienne topory: spod podłogi stajni w Newmarket-on-Fergus oraz wmurowany w ścianę obory w Cloonagun (ryc. 11:12) (Dowd 2018, 463). Z kolei neolityczny młot kamienny znajdował się w ścianie stajni w Drumeague (Penney 1976, 71). Polerowany topór $\mathrm{z}$ kamienia wbudowano także w mur kościoła św. Flananna w Killaloe (Penney 1976, 71).
Z Wielkiej Brytanii warto wspomnieć o niedawno odkrytym niewielkim fragmencie polerowanej siekiery neolitycznej znalezionej podczas usuwania nawarstwień zalegających pod podłogą kuchni domu w Silverdale (ryc. 11:13). Analiza dendrochronologiczna wykazała, że pochodzi on z początku XVIII w., najprawdopodobniej z 1713 r., choć niektóre belki są starsze i pochodzą ze średniowiecza. Siekierę wykonano z drobnoziarnistego tufu wulkanicznego (Elsworth, Boughton 2016, 8, ryc. 1). Można również wskazać na znaleziska z Londynu, m.in. na neolityczny topór $\mathrm{z}$ anglosaskiego budynku w Westminster (Treasury Gree), który został w nim z dużym prawdopodobieństwem wmontowany jako ochronny talizman (Merrifield 1987, 12-13). Z kolei pod paleniskiem domu pamiętającego czasy elżbietańskie w Langham (Essex) natrafiono na topór z epoki brązu (Ellis Davidson 1965, 6-7).

Wspomnieć warto także o zespole wyrobów neolitycznych pochodzących z osady użytkowanej w VIVIII w. w Develier-Courtételle (Szwajcaria). Zidentyfikowano tam fragmentarycznie zachowane topory, siekiery, dłuto i ciosło (ryc. 12:1-7). Większość z nich odkryto w części zniszczonej przez pożar w końcu VII w. (Rebmann 2006).

Istnieją również znaleziska z Francji. Jednym $\mathrm{z}$ nich jest jadeitowa siekiera odkryta w Saint-Aubin (Szampania) (ryc. 12:8). Natrafiono na nią pomiędzy dwoma dużymi kamieniami ściany nowożytnego domu (Daunay 1978, 7-8). Na dużą starannie obrobioną siekierę natrafiono przy rozbiórce starego domostwa w Martot (Normandia). Znajdowała się ona pod progiem (Vesly 1909, 50). Podobne przykłady znaleźć można w starszych pracach (m.in. w Baudouin, Bonnemère 1904; Baudet 1907; Saintyves 1936). Fragment neolitycznego topora $\mathrm{z}$ amfibolitu w merowińskim grobie męskim nr $9 \mathrm{w}$ Varangéville (Grand Est). Pierwotnie znajdował się on w sakwie, z której zachowało się zapięcie (Salin, France-Lanord 1946, 225, 239 , ryc. 32).

W części produkcyjno-warsztatowej klasztoru San Vincenzo al Volturno (Isernia, Włochy) znaleziono liczne pradziejowe wyroby (głównie z nawarstwień i obiektów z VIII-IX w.). Większość to zabytki krzemienne, ale stwierdzono też dwie kamienne siekiery $\mathrm{z}$ neolitu lub eneolitu (ryc. 12:9-10). Jedna miniaturowa, wykonana $\mathrm{z}$ drobnoziarnistego amfibolitowego łupku barwy zielonej, odkryta w warstwie śmietniskowej wiązanej z fazą 5a2 z lat około 842-848 (Francis, Kline 2014, s. 402, 408 [nr kat. 64], ryc. 9.4). Drugi okaz jest zachowany fragmentarycznie, powstał 


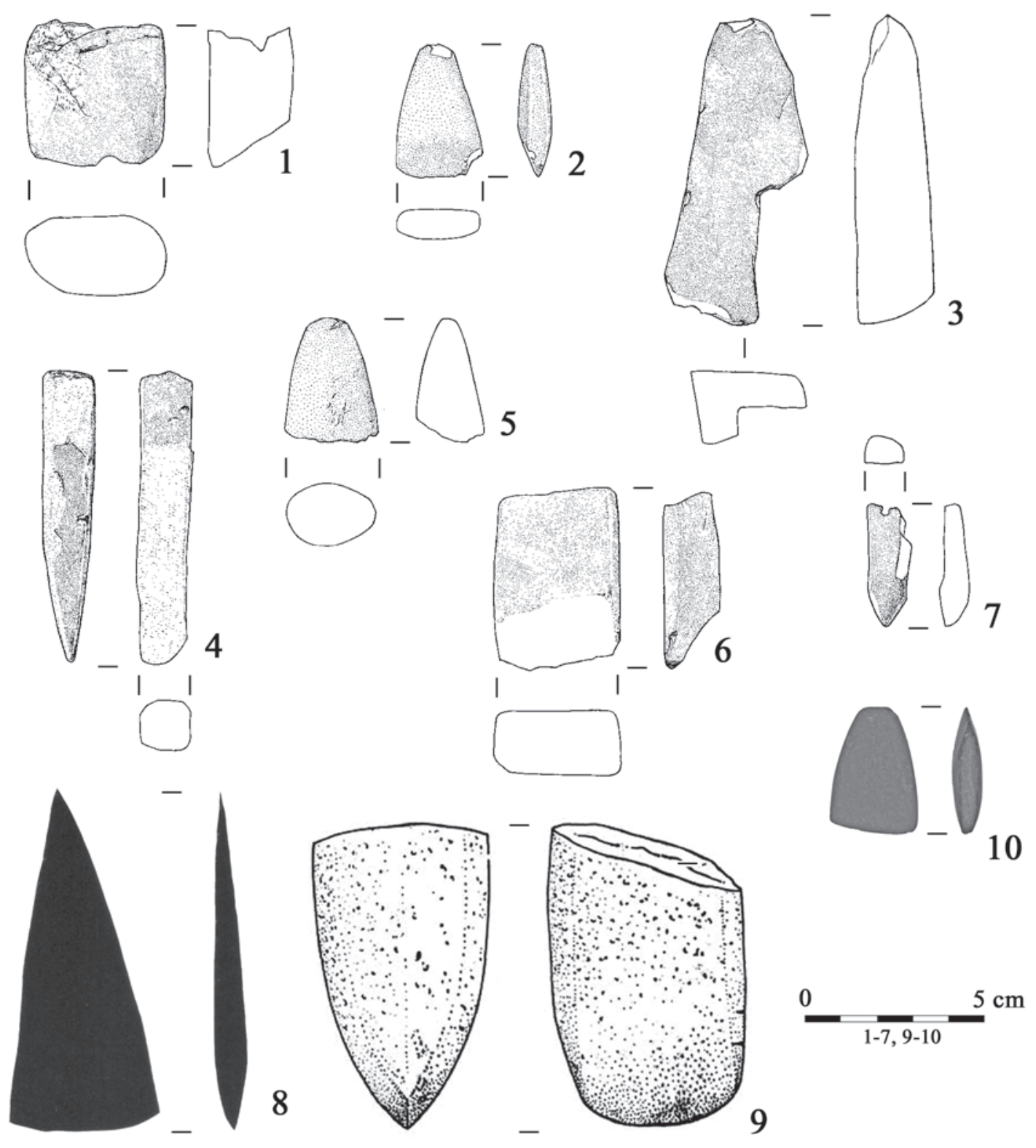

Ryc. 12. Kamienie piorunowe z terenu Szwajcarii (1-7), Francji (8) i Włoch (9-10): 1-7 - Develier-Courtételle (wg Rebmann 2006, tabl. 64:4, 68:25, 27-29, 31-32); 8 - Saint-Aubin (wg Daunay 1978, ryc. na s. 8); 9-10 - San Vincenzo al Volturno (wg Francis, Kline 2014, ryc. 9.4-5). Ryc. 8 nieskalowana. Oprac. T. Kurasiński Fig. 12. Thunderstones from Switzerland (1-7), France (8) and Italy (9-10): 1-7 - Develier-Courtételle (after Rebmann 2006, Table 64:4, 68:25, 27-29, 31-32); 8 - Saint-Aubin (after Daunay 1978, Fig. on p. 8); 9-10 - San Vincenzo al Volturno (after Francis, Kline 2014, Fig. 9.4-5). Fig. 8 unscaled. By T. Kurasiński

z drobnoziarnistej ciemnoszarej skały magmowej w typie bazaltu. Znaleziono go wśród spalonych dachówek wewnątrz pomieszczenia magazynowego (D - spichlerz), zniszczonego w 2. połowie IX w. Taka lokalizacja sugeruje, że przedmiot wisiał na krokwiach lub na szczycie dachu (Francis, Kline 2014, 402, 409 [nr kat. 70], ryc. 9.5).

Wiele kamiennych artefaktów pozyskano z terenu Estonii, choć w odniesieniu do znacznej ich części nie ma absolutnej pewności kontekstu chronologicznego. Unikalnym znaleziskiem jest fragment kamiennego topora, zbliżonego do okazów kultury ceramiki sznurowej ze wzgórza zamkowego w Lihula. Wykonano go z wapienia, co jest rzadkością wśród tego rodzaju znalezisk (ryc. 13:1). Topór został zlokalizowany w pobliżu pozostałości XIII-XIV-wiecznego budynku, być może więc pierwotnie umieszczono go w okapie. Należy jednak liczyć się z ewentualnością, że nie jest to 

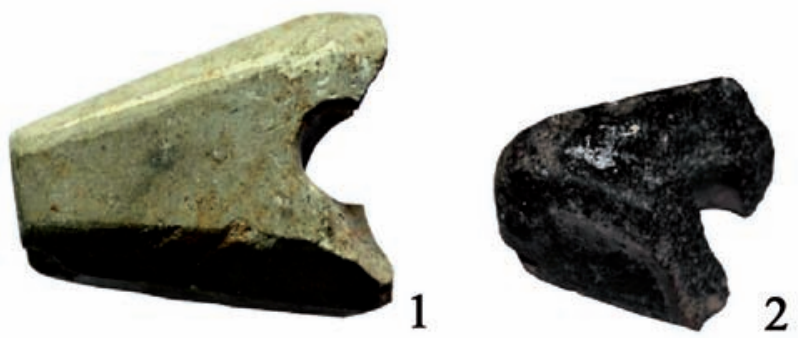

2

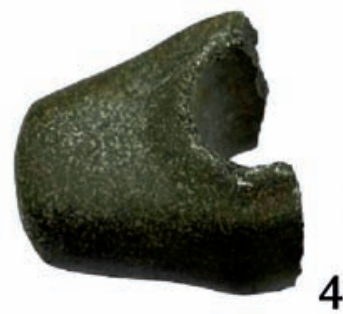

4

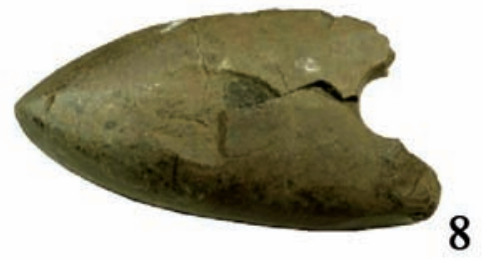

8

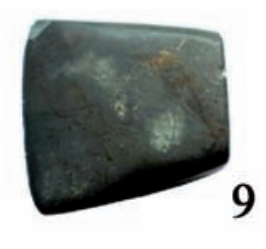

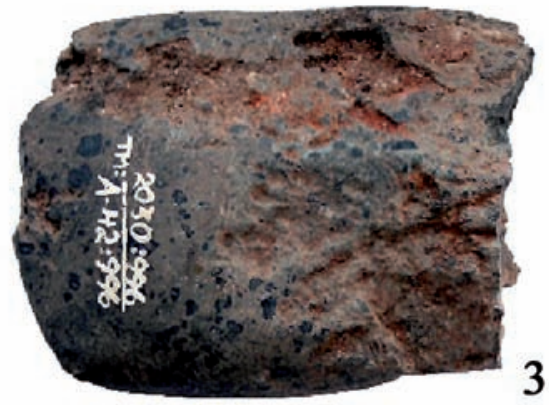

3
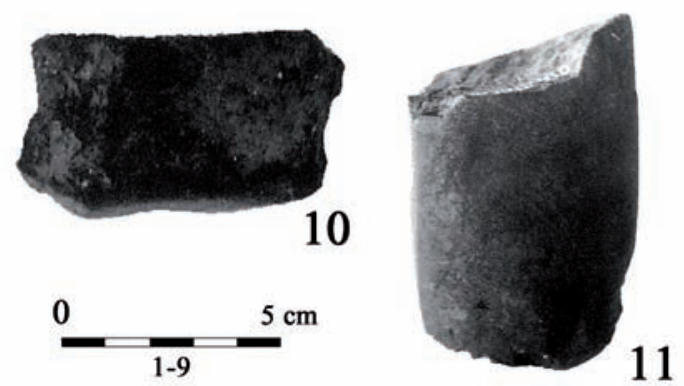

Ryc. 13. Kamienie piorunowe $\mathrm{z}$ terenu Estonii (1-9) i Finlandii (10-11): 1 - Lihula (wg Johanson 2018a, ryc. w tab. 3, poz. 28); 2-6 - Tartu (wg Johanson 2018a, ryc. w tab. 3, poz. 110, 112, 117-119); 7-8 - Pada I (wg Johanson 2018a, ryc. w tab. 3, poz. 33, 35); 9 - Tallin (wg Johanson 2018a, ryc. w tab. 3, poz. 10); 10-11 - Luistari, groby nr 812 i 854 (wg Lehtosalo-Hilander 2000, tabl. 33, 40). Ryc. 10-11 nieskalowane. Oprac. T. Kurasiński

Fig. 13. Thunderstones from Estonia (1-9) and Finland (10-11): 1 - Lihula (after Johanson 2018a, Fig. in Table 3, pos. 28); 2-6 - Tartu (after Johanson 2018a, Fig. in Table 3, pos. 110, 112, 117-119); 7-8 - Pad I (after Johanson 2018a, Fig. in Table 3, pos. 33, 35); 9 - Tallinn (after Johanson 2018a, Fig. in tab. 3, pos. 10); 10-11 - Luistari, tombs No. 812 and 854 (after Lehtosalo-Hilander 2000, Tables 33, 40). Fig. 10-11 unscaled. By T. Kurasiński

fragment topora, ale wapienny element konstrukcyjny (Johanson 2018a, 149-150, tab. 3, poz. 28).

Kilka egzemplarzy zebrano $\mathrm{z}$ warstw średniowiecznych i nowożytnych w różnych częściach Tartu (ryc.13:2-6)(Johanson2018a, 146-149, 168, tab.3, poz. 110, 112, 114-119). Na jeden $z$ fragmentarycznie zachowanych toporów natrafiono w warstwie destrukcyjnej powstałej po zawaleniu się średniowiecznej ściany zamku. Ma on uszkodzone powierzchnie świadczące o intensywnym użytkowaniu. Okoliczności odkrycia mogą wskazywać na umieszczeniu przedmiotu w murze (Johanson 2018a, 147, tab. 3, poz. 110). W ścianie zapewne zamurowany był także fragment ostrza odkryty na osadzie z późnej epoki żelaza i średniowiecza usytuowanej poniżej wzgórza zamkowego (Johanson 2018a, 148, tab. 3, poz. 112). Kolejny kamienny topór został znaleziony pod drewnianą ulicą z końca XIII i pocz. XIV w. Wtedy też zapewne go tam umieszczono bądź wyrzucono (Johanson 2018a, 148 , tab. 3, poz. 116). W innej części miasta, w miejscu odkrycia pozostałości trzech drewnianych budynków z XVII-XVIII w., znaleziono jeszcze jeden częściowo zachowany egzemplarz. Kontekst znalezienia może sugerować jego ukrycie pod progiem (Johanson 2018a, 148, tab.3, poz. 117). Fragment późnoneolitycznego topora (porfir) znaleziono ponadto $\mathrm{w}$ warstwie pomiędzy dwoma kamiennymi budynkami, w której znajdowały się zabytki od X do XVII-XVIII w. (Johanson 2018a, 148-149, tab. 3, poz. 119). Pozyskano także cztery uszkodzone ciosła i topory $\mathrm{z}$ wczesnośredniowiecznej osady w Pada I, z których jeden związany był przypuszczalnie $\mathrm{z}$ paleniskiem (ryc. 13:7-8) (Johanson 2018a, 146, tab. 3, poz. 33-36). Można również wskazać na ciosło z Tallina. Ślady 
na jego powierzchni wskazują na wtórne zużycie, do czego doszło najprawdopodobniej w średniowieczu (ryc. 13:9) (Johanson 2018a, 150, tab. 3, poz. 10).

Przedmioty takie trafiały również do jam grobowych. W miejscowości Piila na wyspie Saaremaa $\mathrm{w}$ grobie z okresu wikińskiego natrafiono na fragment kamiennego topora (Johanson 2009, 151). Artefakty $\mathrm{z}$ epoki kamienia znajdowały się też $\mathrm{w}$ młodszych pochówkach. Należy wspomnieć zwłaszcza o kamiennym toporze na późnośredniowiecznym cmentarzu w Hargla w południowo-wschodniej Estonii. W grobie znaleziono ponadto zapinkę i monetę z $1400 \mathrm{r}$. (Johanson 2009,152$)^{11}$.

Znanych jest ponadto cały szereg kamiennych artefaktów pradziejowych wykorzystanych wtórnie w przeszłości, potwierdzonych badaniami etnograficznymi (zebrane w Johanson 2018a, 158-159).

Pokaźny zbiór omawianych zabytków pochodzi z Finlandii, przy czym do ukrycia większości z nich najprawdopodobniej doszło w XIX w. (Hukantaival 2016; zob. też Hukantaival 2019). W wielu przypadkach istnieją jednak informacje dotyczące lokalizacji. Przykładowo, neolityczny topór z epoki kamienia dostarczony do Muzeum Narodowego w 1934 r. odkryto podczas burzenia starej obory w majątku Rauskala we wsi Viitaila. Znajdował się on w suficie w otworze wydłubanym w belce i co ciekawe był opasany gałązkami (Hukantaival 2016, 182, 343). Warto wspomnieć o niedokończonym toporze neolitycznym znalezionym na polu, a następnie umieszczonym w palenisku domu we wsi Karvoskylä. Później topór ten trafił do sauny, gdzie został odkryty podczas jej rozbiórki (Hukantaival 2016, 183, 371). Tylko jeden egzemplarz w tamtejszym materiale odkryto w kontekście średniowiecznym. Jest to neolityczne ciosło znalezione pod narożnikiem drewnianego domostwa $\mathrm{z}$ kamiennym piecem z XV-XVI w. podczas badań ufortyfikowanej osady w Lopotti (Hukantaival 2016, 82, 360). Inny pojedynczy okaz ma z kolei metrykę wczesnonowożytną. Chodzi o dłuto neolityczne pozyskane w 1883 r., które znaleziono w podwalinie ściany starego, rozebranego budynku należącego do majątku Anttila we wsi Ahmoo (dziś Karkkili). Przedmiot ten przechowywano w majątku przez co najmniej 200 lat po jego odkryciu, co oznacza, że został znaleziony pod koniec XVII w. (Hukantaival 2016, 182-183, 342).

11 Ciosło kamienne znaleziono również na cmentarzysku z XV-XVI w. w Tartu, przy czym są trudności w przyporządkowaniu go do konkretnego pochówka (Johanson 2018a, 149, tab. 3, poz. 118).

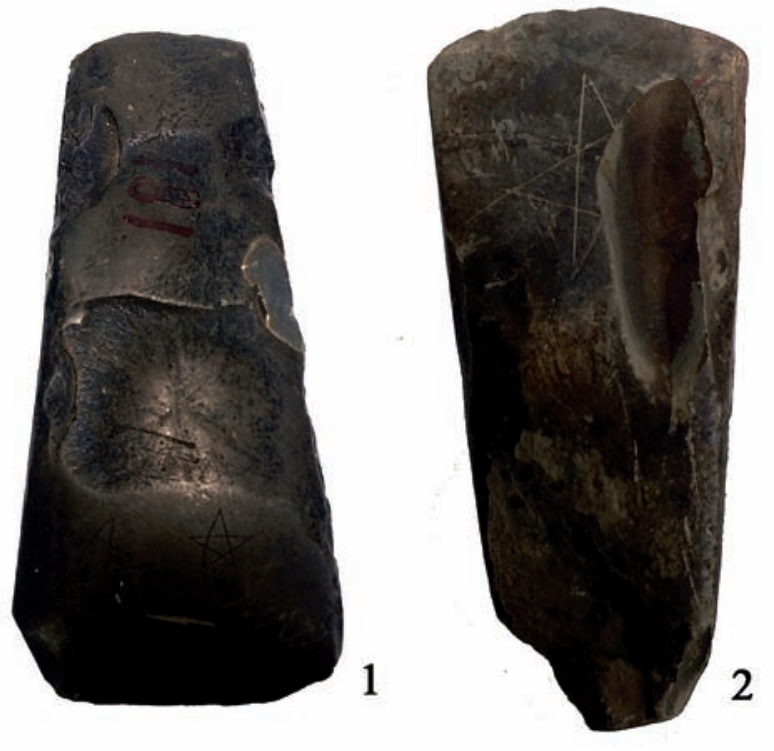

Ryc. 14. Kamienie piorunowe $\mathrm{z}$ terenu Karelii:

1 - Kaksoistaltta; 2 - Tasataltta (wg Kunnas-Pusa 2016, ryc. 2). Ryc. nieskalowane. Oprac. T. Kurasiński

Fig. 14. Thunderstones from Karelia:

1 - Kaksoistaltta; 2 - Tasataltta (after Kunnas-Pusa 2016, Fig. 2). Fig. unscaled. By T. Kurasiński

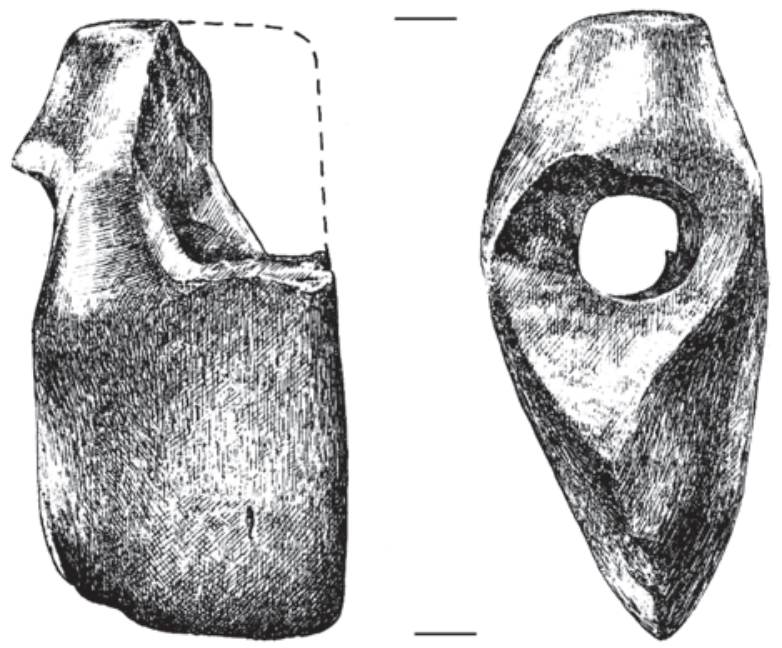

Ryc. 15. Kamień piorunowy z Altene (Łotwa) (wg Graudonis 1983, ryc. 6). Ryc. nieskalowana. Oprac. T. Kurasiński

Fig. 15. Thunderstones from Altene (Latvia) (after Graudonis 1983, Fig. 6). Fig. unscaled. By T. Kurasiński

W dwóch grobach (nr 812 i 854) na cmenarzysku w Luistari (Eura) natrafiono na kamienne dhuto i fragment siekiery (ryc. 13:10-11)(Lehtosalo-Hilander 2000, 95, 107, tabl. 33, 40). Inne przykłady z pochów- 
ków z okresu wędrówek ludów i młodszych zebrała A. Wessman $(2009,75)$.

Warto tu również wspomnieć o znaleziskach z dawnej gminy fińskiej Jaakima w Karelii, obecnie znajdującej się w granicach Rosji. Wiele okazów pradziejowych, głównie kamiennych toporów i dłut, mających wtórne znaczenie magiczne pozyskano od miejscowej ludności, która znajdowała i przechowywała je od pokoleń. Na kilku z tych przedmiotów wygrawerowane zostały symbole geometryczne, np. z Kaksoistaltta, Poikkikirves i Tasataltta (ryc. 14) (Kunnas-Pusa 2016).
Można wskazać na znaleziska $\mathrm{z}$ terenów bałtyjskich. Z Lotwy na grodzisku w Lokstene (III-XV w.) znaleziono 2 topory i siekierę (Mugurēvičs 1977, 56, 58, 60, 73, ryc. 42, tabl. XVI:9; Vasks 2003, 31). Przypuszczalnie do omawianych znalezisk zaliczyć należy także uszkodzony kamienny topór odkryty na terenie średniowiecznego zamku w Altene z końca XIV w. (ryc. 15), przy czym wiązać należałoby go ze wcześniej istniejącą tu ufortyfikowaną osadą (VI/VIIXIII w.) (Graudonis 1983, 43, ryc. 6).

Archaika te odnotowano ponadto w materiałach wschodnioeuropejskich (Białoruś, Rosja, Ukraina).
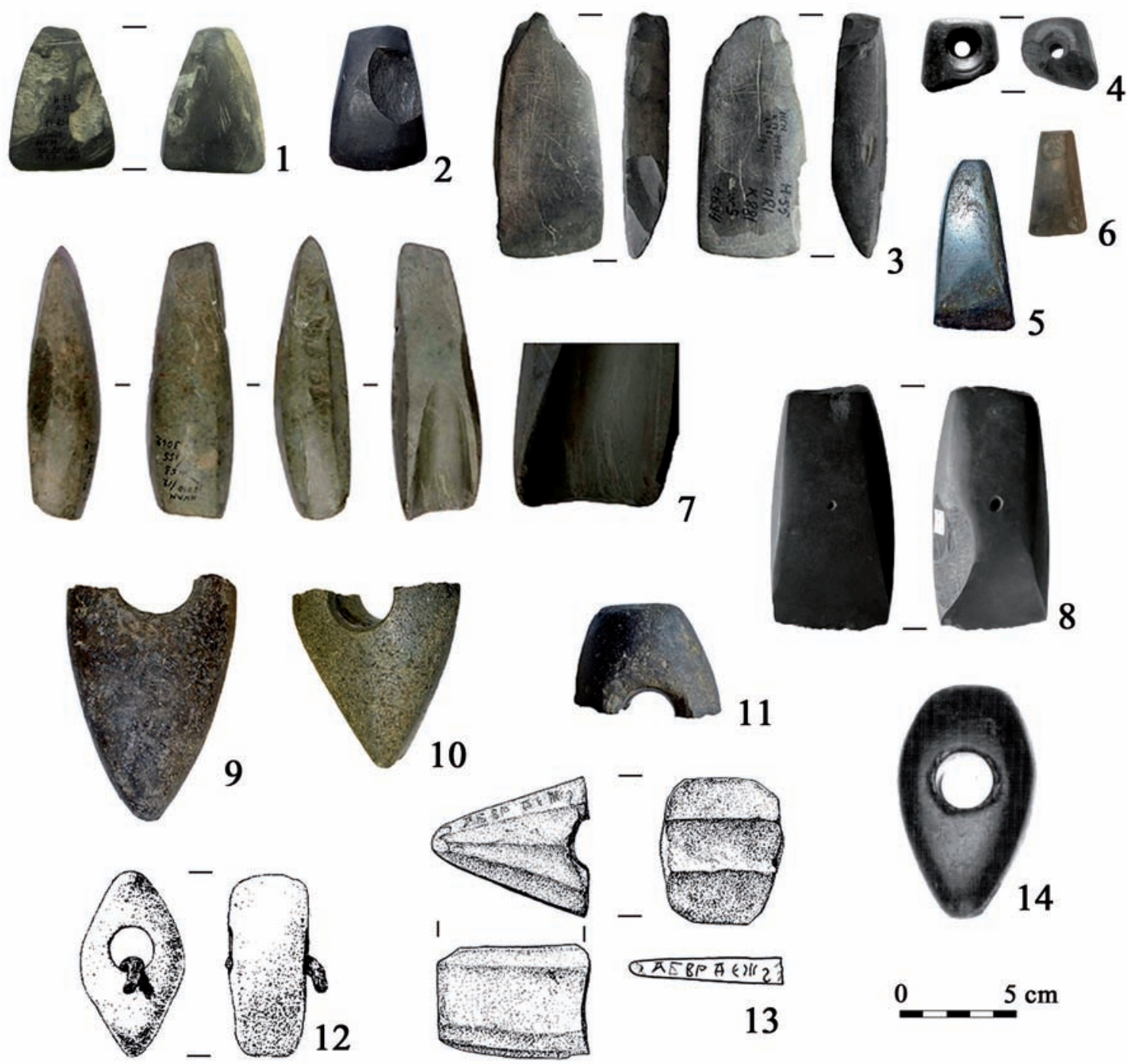

Ryc. 16. Kamienie piorunowe z terenu Rosji: 1-11 - Nowogród Wielki (wg Musin et al. 2018, ryc. 8, 9, 10; Tyanina 2018, ryc. 3:b-c); 12 - Hlepen (wg Gasanov 2018, ryc. na s. 119); 13 - Twerski Kreml (wg Lapshin 2009, ryc. 61:1); 14 - Bor (wg Shevelev 2005, ryc. na s. 3). Oprac. T. Kurasiński

Fig. 16. Thunderstones from Russia: 1-11 - Veliky Novgorod (after Musin et al. 2018, Fig. 8, 9, 10; Tyanina 2018, Fig. 3:b-c); 12 - Hlepen (after Gasanov 2018, Fig. on p. 119); 13. - Tver Kremlin (after Lapshin 2009, Fig. 61:1); 14 - Bor (after Shevelev 2005, Fig. on p. 3). By T. Kurasiński 
Duży ich zbiór odnotowano w nawarstwieniach Nowogrodu Wielkiego, począwszy od 2. połowy X w. aż do XV w. Wśród nich można wyróżnić m.in. ciosła i topory z neolitu i epoki brązu (ryc. 16:1-11) (Tyanina 2008; 2018; Zheltova et al. 2015, 214-216, 237, 239-240; Zheltova et al. 2017; Musin et al. 2018, 21, 30-31, 34).

Wyroby z tych surowców odkryto także na średniowiecznych stanowiskach w międzyrzeczu górnego Prutu i środkowego Dniestru (Ukraina). Na grodzisku w Czerniowcach (XIII w.) w przy ścianie jednego $z$ domostw natrafiono na granitowy topór. Przedmiot pochodzi z epoki brązu (Pyvovarov 2008, 108). Kamienne eneolityczne dłuto znaleziono podczas badań XIV-wiecznego grodziska w miejscowości Zelena Lipa, w pozostałościach drewnianego budynku wraz ze średniowiecznymi militariami (Pyvovarov 2008, 108).

Podobne znaleziska mamy także z innych stanowisk staroruskich. W miejscowości Hlepen (region smoleński) w zniszczonym budynku z XIII w. znaleziono siekieromłot $\mathrm{w}$ kształcie rombu z żelaznym prętem w otworze, który mocował toporzysko (ryc. 16:12) (Gasanov 2018, ryc. na s. 119; Pyvovarov, Il'kiv 2014, 7). Z nawarstwień z połowy XIV w. Twerskiego Kremla pochodzi fragment kamiennego topora z epoki brązu, będącego imitacją egzemplarzy metalowych (ryc. 16:13). Powierzchnię jednej z grani pokrywają ułożone kolejne pierwsze litery cyrylickiego alfabetu (azbuka) (Rozhdestvenskaya 2001, 211, 214, ryc. 2:1; Lapshin 2009, 125, 139, ryc. 61:1). Późnoneolityczne topory i ciosła mamy również z Pskowa, które należy wiązać z funkcjonowaniem miasta w średniowieczu, tym bardziej, że jeden z okazów jest wtórnie perforowany (Johanson 2018a, 137).

Do powyższej listy dodać można klinopodobny toporek znaleziony w męskim grobie na cmentarzysku Wiatyczów w Staro Dar'ino III z XI-XII w. (Nedoshivina 1976, 50, 52 [przyp. 5]).

Są też znaleziska pochodzące z młodszych kontekstów. W zbiorach Muzeum Kargopolskiego przechowywany jest starannie wypolerowany kamienny topór znaleziony w opuszczonej wsi Bor nad jeziorem Kenozero w północnej Rosji. Reprezentuje on kulturę fatianowską (ryc. 16:14). Przedmiot znajdował się w sieni jednej z tamtejszych chałup chłopskich (Shevelev 2005, 2).

Kilka okazów pochodzi również z ośrodków wczesnomiejskich z terenu Białorusi. Warto przede wszystkim przywołać znaleziska z Homla. Dwa ciosła kamienne (epoka brązu) znaleziono w obrębie warsztatów z XII-początku XIII w. (wytwarzającego

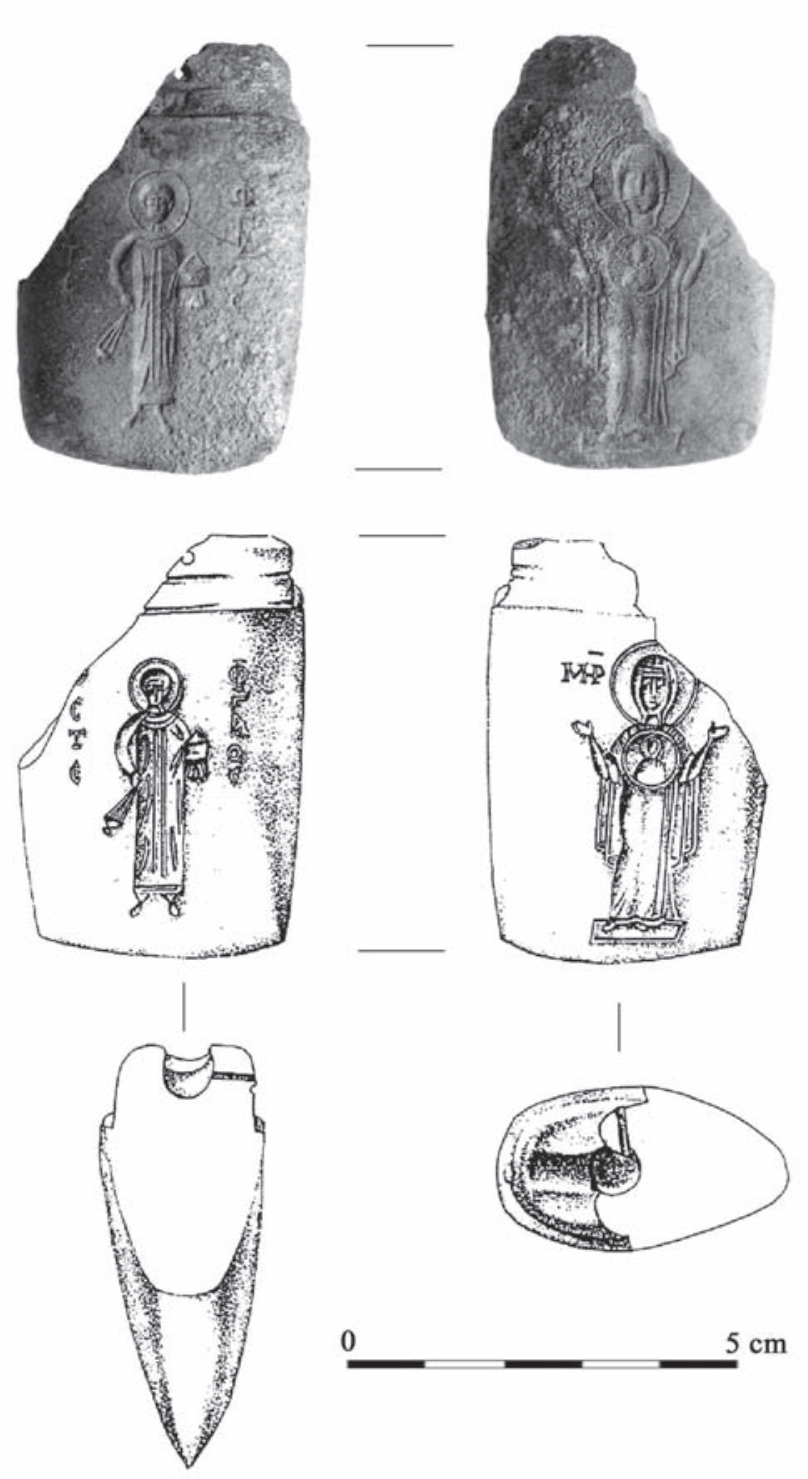

Ryc. 17. Amulet z Kijowa (wg Musin et al. 2018, ryc. 1). Oprac. T. Kurasiński

Fig. 17. An amulet from Kiev (after Musin et al. 2018, Fig. 1). By T. Kurasiński

militaria i złotniczego), z kolei na fragment topora natrafiono w obiekcie z XI-XII w. (Makushnikov 2009, 134). Kamienne topory z epoki brązu odkryto również w Witebsku: w XIII-wiecznych domostwach Zamku Dolnego i w nawarstwieniach z 1. połowy XII w. na Zamku Górnym (Bubenko 2004, 113, ryc. 100:19-21; Koledinskiy 2020, 6, ryc. 7:2-3; tu inne przykłady).

$\mathrm{Na}$ tle powyższych znalezisk wyróżnia się częściowo zachowany, eneolityczny topór kamienny (skała zbliżona do diorytu), na którym z jednej strony wyobrażono Matkę Bożą, a po drugiej świętego Szczepana, odkryty w spalonym budynku gospodarczym lub produkcyjnym z końca XII-1. połowy XIII w. na 
terenie monasteru św. Michała Archanioła o Złotych Kopułach w Kijowie. W górnej jego części widoczne są otwory-kanaliki i dookolne rowki, niezbędne do zamocowania metalowej, zapewne srebrnej, oprawy (ryc. 17) (Ivakin 2002; 2007, 40-42, ryc. 22; Ivakin, Chernetsov 2001; 2002; Ivakin, Putsko 2005, 94-95, ryc. 1).

Neolityczne ciosło z wyobrażeniem krzyża o rozszerzających końcach odkryto ponadto w pobliżu wsi
Lyubenovo w Bulgarii (ryc. 18:1) (Aladzhov, Balabanyan 1972, 130, ryc. 34).

Pradziejowe topory kamienne pełniące funkcję kamieni piorunowych do niedawna były często spotykane w Rumunii. Zwracają uwagę okazy pochodzące z miejscowości Drăguș w Transylwanii (ryc. 18:2-5) (Ofrim 2019, 98, ryc. 1-2).

Używano ich także na Węgrzech, przykładowo przez pasterzy w rejonie górskim Börzsöny (ryc. 18:6)

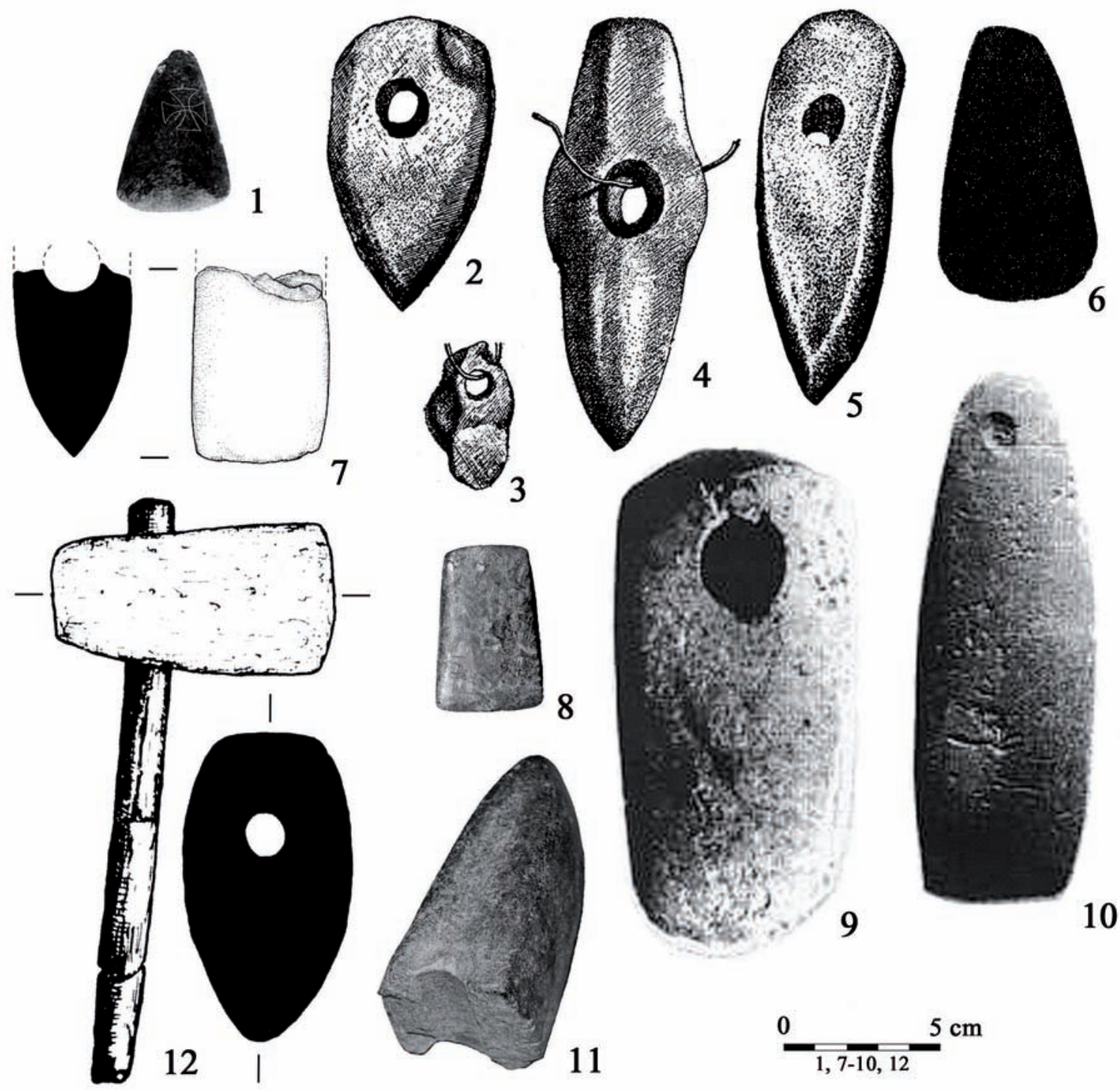

Ryc. 18. Kamienie piorunowe z terenu Bułgarii (1), Rumunii (2-5), Węgier (6), Chorwacji (7-11) i Polski (12): 1 - Lyubenovo (wg Aladzhov, Balabanyan 1972, ryc. 34); 2-5 - Drăguș (wg Ofrim 2019, ryc. 1-2); 6 - rejon Börzsöny (wg Hála 2016b, ryc. 4); 7 - Baba lokva (wg Burić 2015, ryc. 2); 8 - Paka (wg Šimek 2010, ryc. 3); 9 - Zlogonje (wg Šantalab 2008, ryc. 7); 10 - Zalužje (wg Šantalab 2008, ryc. 8); 11 - Crkovec (wg Šimek 2010, ryc. 4); 12 - Gdańsk (wg Lepówna 1981, ryc. 7:a). Ryc. 2-6 i 11 nieskalowane. Oprac. T. Kurasiński

Fig. 18. Thunderstones from Bulgaria (1), Romania (2-5), Hungary (6), Croatia (7-11) and Poland (12): 1 - Lyubenovo (after Aladzhov, Balabanyan 1972, Fig. 34); 2-5 - Drăguș (after Ofrim 2019, Fig. 1-2); 6 - Börzsöny area (after Hála 2016b, Fig. 4); 7 - Baba lokva (after Burić 2015, Fig. 2); 8 - Paka (after Šimek 2010, Fig. 3); 9 - Zlogonje (after Šantalab 2008, Fig. 7); 10 - Zalužje (after Šantalab 2008, Fig. 8); 11 - Crkovec (after Šimek 2010, Fig. 4); 12 - Gdańsk (after Lepówna 1981, Fig. 7:a). Fig. 2-6 and 11 unscaled. By T. Kurasiński 
(Hála 2016a, 45; Hála 2016b, 90, ryc. 4; tam starsza literatura).

Również w Chorwacji zebrano kilka interesujących nas znalezisk. Jednym z nich jest fragment topora odkryty na osadzie Baba lokva w Kaštel Štafilić zamieszkiwanej w XIV-XVII w. (ryc. 18:7) Odkryto go w bezpośrednim sąsiedztwie struktur kamiennych zabudowań, przypuszczalnie gospodarczych, przynależnych do pobliskiego domostwa, w starszej, średniowiecznej warstwie osadniczej. Na toporze stwierdzono ślady okopcenia (Burić 2015). Innym okazem jest niewielka kamienna siekiera (przypuszczalnie eneolityczna), którą znaleziono w obrębie późnośredniowiecznej twierdzy Paka na wzgórzu Gradišće w pobliżu Novi Marof, na południe od Varaždina (ryc. 18:8). Zalegała ona na majdanie $w$ warstwie zawierającej liczne zabytki z XIII i XIV w. (Šimek 2010). Liczną kolekcję kamieni piorunowych, z których wiele znajdowało się w ścianach i na strychach, zebrano z okolic Višnjica w żupanii varażdińskiej (ryc. 18:910) (Šantalab 2008). Dodajmy, iż we wsi Crkovec, położonej w tym samym północnochorwackim rejonie, fragment topora zmieniał lokalizację i przechowywany był w trzech kolejnych domach (ryc. 18:11) (Šimek 2010, 145, ryc. 4).

Biorąc pod uwagę zasięg omawianego zjawiska, zastanawia wyraźny deficyt podobnych, dobrze udokumentowanych, znalezisk z ziem obecnej Polski. W świetle poczynionych poszukiwań można wskazać na odosobnione przypadki odkrycia rozpatrywanych przedmiotów, ograniczających się do północnych połaci kraju. Należy do nich siekiera w szarego porfiru skandynawskiego, łączona z wytwórczością ludności kultury pucharów lejkowatych. Jej obecność stwierdzono w wypełnisku późnośredniowiecznej latryny (obiekt nr 6) zarejestrowanej w Stargardzie w obrębie Starego Miasta (Szeremeta 2019). Innym znaleziskiem jest neolityczny topór kamienny odkryty w murze przykościelnego cmentarza w miejscowości Ostroróg w pobliżu Czaplinka (Kowalski, Matuszewski 2012, 69). Z kontekstem chronologicznie starszym wiąże się kolejny topór z młodszej epoki kamienia, zaopatrzony w drewniany trzonek (ryc. 18:12). Natrafiono na niego podczas badań prowadzonych na grodzisk w Gdańsku (stan. 1), wewnątrz domostwa nr 59 (6 poziom osadniczy ${ }^{12}$ ), gdzie leżał na powierzchni paleniska (Lepówna 1981, 180, 194, ryc. 7:a). Ponadto

12 Pierwotnie datowany na lata $1180-1205$, a po przeprowadzeniu badań weryfikacyjnych na 2 . ćwierć XII w. (Kościński, Paner 2005, 37 [tab. 3]). fragment siekiery kamiennej pochodzi $\mathrm{z}$ jednego z wczesnośredniowiecznych cmentarzysk wolińskich (stan. 9). Okaz ten znajdował się w nasypie kurhanu nad pochówkiem (nr 81), co budzić może wątpliwości, jeśli chodzi o jego intencjonalne zdeponowanie (Pollex 2010, 200, 509; Kajkowski 2019, 292).

Trudno ocenić, na ile powyższy obraz wynika ze stanu badań, spowodowanego brakiem właściwej identyfikacji materiału zabytkowego ${ }^{13}$, na ile zaś stanowi odzwierciedlenie faktycznych preferencji wierzeniowych, w którym omawiane wyroby nie odgrywały istotniejszej roli ${ }^{14}$. Jest to jednak temat na osobne rozważania.

\section{KWESTIE ZNACZENIOWE I WTÓRNE WYKORZYSTANIE KAMIENI PIORUNOWYCH}

Z sumarycznego przeglądu znalezisk wynika, iż rozpatrywane przedmioty odkrywane są w różnych miejscach budynków mieszkalnych i gospodarczych, a nawet sakralnych (głównie w ścianach, piwnicach i kominach oraz pod podłogą, pod progiem, w fundamentach i w obrębie dachu), zarówno w miastach, zamkach i na grodziskach, jak i na wsiach (ryc. 19). Niekiedy umieszczane były w mostach i murach obronnych, a ponadto w studniach, grobach, skarbach, pod ulicami i przy ciekach wodnych. Przekłada

13 Przykładowo, można zastanawiać się, czy przypadkowo znaleziony podczas kopania fundamentów w centrum Szczecinka (ul. Strażacka) topór kamienny, wiązany z kulturą łużycką, nie pełnił funkcji kamienia piorunowego. $\mathrm{Na}$ jego powierzchniach bocznych wyryto krzyże i równoległe linie (Sikora 1966; Borkowski, Kuczkowski 2013, 386, ryc. 739). Taka interpretacja pojawia się w przypadku przypadkowo znalezionego w Busku-Zdroju zdobionego toporka typu ślężańskiego kultury ceramiki sznurowej, na którym widoczne są ślady wtórnego szlifowania (Hadarnik 2000, 148).

14 Wynikałoby to $\mathrm{z}$ większego znaczenia przypisywanego belemnitom, ewentualnie też fulgurytom, potwierdzonego bogatym zasobem nazewniczym odnoszącym się do tych skamieniałości (zob. Mazurkiewicz 1988; Brzozowska 1996; Lebeda 2002, 135-143), aczkolwiek przekazy etnograficzne z terenów dzisiejszej Polski dają również świadectwo magicznego i leczniczego wykorzystywania kamiennych i krzemiennych przedmiotów pradziejowych (Biegeleisen 1929, 342-343; Horoszkiewicz 1950; Szyfer 1969, 67-68, 78; Kaczorowski 2003, 102). 


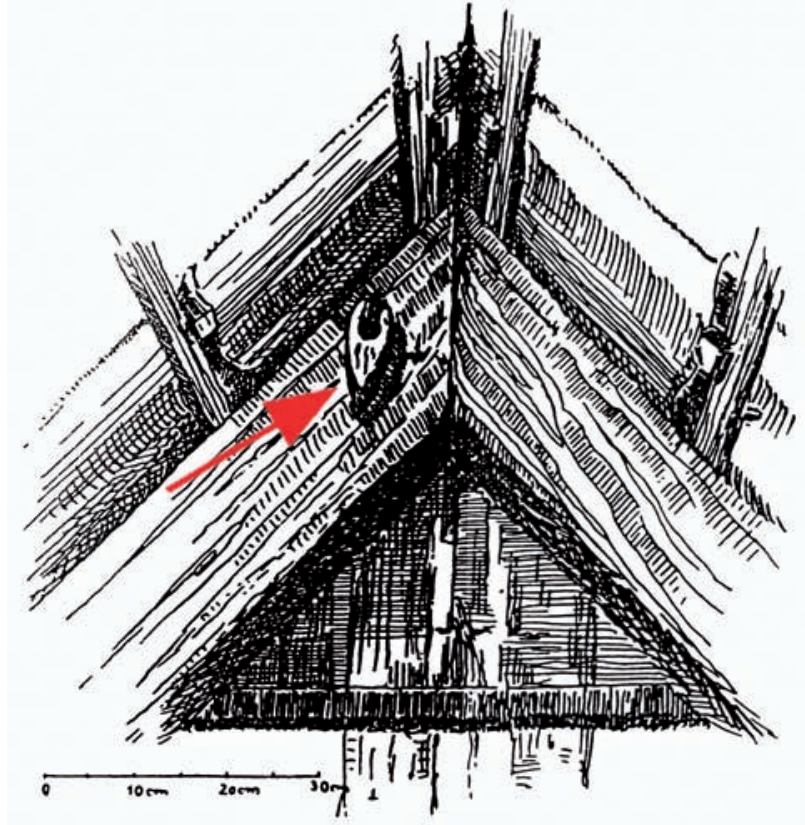

Ryc. 19. Kamień piorunowy zawieszony w kalenicy stodoły w Banteln (Niemcy) (wg Barner 1957, ryc. 2). Oprac. T. Kurasiński

Fig. 19. A thunderstone installed in the ridge of a barn in Banteln (Germany) (after Barner 1957, Fig. 2). By T. Kurasiński

się to na treści przypisywane kamieniom piorunowym i formy ich wykorzystywania w nowych realiach kulturowych.

\section{Kamienie piorunowe w ,tradycyjnym" i ,uczonym" systemie myślenia}

Wyobrażenia dotyczące wszelkiego rodzaju kamieni i strzałek piorunowych czy też klinów gromowych ogniskowały się przede wszystkim wokół zjawiska atmosferycznego - burzy z towarzyszącymi jej efektami świetlnymi i dźwiękowymi - błyskawicą i grzmotem (zob. Czaplicka 1985). W europejskiej tradycji ludowej wierzono, że przedmioty te spadają na ziemię z nieba pod postacią pioruna lub wraz z piorunem, albo tworzą się ze stopionego piasku w miejscu jego uderzenia w ziemię. Wszędzie tam, gdzie kamienne narzędzia $w$ jakikolwiek sposób wiązane były z piorunem, uznawano je za pociski, wierząc, że grzmot powstaje w wyniku głębokiego wbicia się ich w ziemię (o pochodzeniu kamieni piorunowych zob. Sklenáŕ 1999, 41). W morawskim i słowackim folklorze im silniejszy był piorun, tym należało się spodziewać większego kamienia (Plessingerová, Vařeka
1999, 210). Dopiero po upływie pewnego czasu obiekty te stopniowo unosiły się na powierzchnię gruntu, gdzie dawały się odszukać ${ }^{15}$. Stąd dawnym odkrywcom znaleziska takie jawiły się jako niezwykłe wytwory, wywodzące się z innego świata, które swoje szczególne właściwości zawdzięczają pozaziemskie$\mathrm{mu}$ pochodzeniu ${ }^{16}$.

Symbolika kamienia piorunowego utożsamiająca pociski - lityczną broń działającą na odległość - z piorunem, wykazuje wyraźne odniesienia mitologiczne poprzez konotacje $\mathrm{z}$ bogami uranicznymi i ich atrybutami w postaci identyfikowanego $\mathrm{z}$ gromem i błyskawicą oręża (Olbrich 1987, 326; Eliade 1993, 16-17, 95-96; Kulmar 2005, 28). Przykładem może być Thor, którego młot Mjölnir po rzucie powracał do swego właściciela, tak samo jak kamień piorunowy po pewnym czasie wynurzał się z głębi ziemi (Motz 1997, 344; Belaj 2007, 124; Søyland 2017, 30; polemicznie Taggart 2018, 155-156). Ta niosąca zniszczenie broń chroniła przed siłami chaosu, uosabianymi przez mityczne monstra, a zarazem przyczyniała się do dobrobytu i płodności (zob. Ellis Davidson 1965; Lindow 1994). Na terenach wschodniosłowiańskich wiara w kamienie piorunowe mogła wiązać się z kultem Peruna (Pyvovarov 2008, 106, 108; Krival'tsevich 1992, 10-11; Shevelev 2005, 3) ${ }^{17}$, natomiast u Finów i Bałtów - odpowiednio z Ukko (Salo 1990,

15 Dane, dotyczące głębokości osiągniętej przez kamienie piorunowe, a także czasu potrzebnego do „wyjścia” ku powierzchni różnią się regionalnie. Często powtarza się liczba siedem (dni, tygodni, miesięcy lub lat) i jej wielokrotność oraz czterdzieści, rzadziej dziewięć czy piętnaście (zob. np. Olbrich 1987; Andree 1889, 30-31; Klecanda 1901, 214; Červinka 1897a, 47-48; Blas de, Maya 1974, 213; Reitinger 1976, 527; García Castro 1988, 438-439; Tolstoy 1995, 562; Laurinkienè 1996a, 24; Laurinkienè 1996b, 109-110; Plessingerová, Vařeka 1999, 210; Sklenář 1999, 24, 44; Muhonen 2006, 10; Belaj 2007, 115, 117 118; Rúa Aller, García Armesto 2010, 65).

16 Niekiedy, jako rzeczywistą przyczynę powyższych przekonań, podaje się obserwowane zjawisko upadku meteorytów (Andree 1889, 30; Olbrich 1987, 328; Fröhlich 1992, 239; Muhonen 2006, 5). Sugeruje to siekiera z wyrytym przedstawieniem komety pochodząca z Lhánic (Morawy). Jakkolwiek nie podano bliższych okoliczności odkrycia tego okazu, wizerunek bez wątpienia naniesiono w późniejszym czasie (Skutil 1963, 85, ryc. 1:a; Koštuř́́k et al. 1986, 211, ryc. 23:4; Fröhlich 1992, 239; Unger 2007, 55). O magicznym i symbolicznym znaczeniu tych obiektów w przeszłości zob. Korpikiewicz 2016.

17 W bezpośrednim związku z kultem Peruna lokowane są wyroby pradziejowe znalezione w Nowogrodzie Wielkim (Tyanina 2018). 
107-108; Muhonen 2006, 7) i Perkunasem (Vasks 2003; Tumènas 2016, 363) ${ }^{18}$.

Wraz z postępami chrystianizacji kompetencje bogów gromowładnych przejęli Bóg i święci, m.in. Eliasz, Paweł i Jerzy, stojący w opozycji do szatana i innych sił demonicznych (Tolstoy 1995, 562; Shevelev 2005; Szczepański 2010, 9; Pyvovarov, Il'kiv 2014, 7; Tyanina 2018, 63). Ludowe przekonanie, że piorun jest w rzeczywistości kamieniem, jest uzasadnione, gdyż sam błysk światła nie mógł spowodować takiego ciosu (grzmotu), a bóg potrzebował konkretnej broni, zdolnej niszczyć złe moce. Tym samym w świadomości ludowej kamienne topory i siekiery w znacznym zakresie stały się reprezentantami boskiego rynsztunku (Ellis Davidson 1965, 6; Demuth 2002, 112; Szczepański 2010, 9). Mity związane z tym wątkiem mogły zatem $\mathrm{w}$ istotnym stopniu zasilać i wspierać wiarę w niebiańskie pochodzenie kamieni piorunowych i zdecydować o ich utożsamianiu ze znajdywanymi wyrobami pradziejowymi.

Przywołane mityczne skojarzenia, ujawniające się w postrzeganiu takich przedmiotów jako obiektów niebiańskich i boskich, znalazły swoje odzwierciedlenie m.in. w folklorze skandynawskim (np. Motz 1997, 337-338; Søyland 2017, 30-31) i słowiańskim (np. Shevelev 2005, 2; Belaj 2007, 115-116; Tyanina 2018, $63)^{19}$. Zawiera je także przywoływane już wcześniej tradycyjne nazewnictwo, przy czym warto ponownie

18 Zdaniem K. Johanson inaczej może to wyglądać w mitologii estońskiej, w której brak bezpośredniego związku między Uku, with appealing to him with requests, making him sacrifices and 'thunderbolts'... (Johanson 2009, 157).

19 Można w tym miejscu przywołać inną genezę omawianych przedmiotów, zaobserwowaną na terenie Rumunii. W wymienionej już wsi Drăguș wspominano o przedmiotach (m.in. miniaturowe wozy, kosy, kamienne młotki, krzyżyki i paciorki) pozostawionych przez istoty żeńskie, zwane w mitologii rumuńskiej jako iele, w miejscach gdzie tańczyły. Wśród nich znajdowały się także kamienie wróżek (the fairies' stones), niektóre o regularnym kształcie i perforowane, z którymi identyfikowano też kamienne topory pradziejowe. Przypisywano im działanie lecznicze (Ofrim 2019, 98-99, ryc. 1-2). Na temat owych mitycznych postaci, będących urodziwymi śpiewaczkami i tancerkami, często o demonicznym i mściwym charakterze zob. Boda 2017; Ghinoiu 2013, 141-143). Określeniu iele przypisuje się pochodzenie starogermańskie, co stanowi nawiązanie do przedchrześcijańskich wierzeń w elfy (Bargan 2015). Zbliżone wierzenia odnotowano w Bretanii (okolice Dinan), wedle których kamienne topory i inne przedmioty czasami na polach pozostawiały wróżki dla odparcia zła i przysporzenia urodzaju (Saintyves 1936, 117-118). podkreślić, iż nie zawsze można mieć pewność, jaki konkretnie rodzaj znaleziska występuje pod daną nazwą ${ }^{20}$.

Mityczno-wierzeniowy obraz świata związany z omawianymi wyrobami nie ograniczał się jednak wyłącznie do sposobu myślenia niewykształconych warstw społecznych. Bardzo długo nie dostrzegano wyraźnego rozróżnienia między tworami naturalnymi a tymi, które były pochodzenia ludzkiego w przekonaniu, że pradziejowe kamienne narzędzia były zrzucanymi z nieba kamieniami piorunowymi lub strzałami elfów (Trigger 2006, 85, 92). Swą unikalną formę osiągały w wyniku pewnego rodzaju naturalnego procesu - powstawały, gdy błyskawica trafiała w ziemię. Zajmujący się tymi znaleziskami dawni uczeni, myśliciele i starożytnicy grupowali je pod dawną grecką nazwą ceraunia (także ceraunium, ceraunius, ceraneus), czyli kamieni piorunowych (łac. lapis fulminaris) (Abramowicz 1979, 128).

Fundamentalne dla toczącej się w kolejnych stuleciach dyskusji na temat proweniencji i znaczenia ceraunii są informacje o kilku ich rodzajach, podane przez Pliniusza Starszego w Historii naturalnej ${ }^{21}$. A. Abramowicz celnie wskazał na trzy zasadnicze elementy tego przekazu, pojawiające się w uczonych dysputach. A mianowicie, że niektóre ceraunie przypominają topory, znajduje się je w miejscach uderzenia przez piorun oraz mają niezwykłe magiczne własności, klasyfikujące je w sferze mityczno-religijnej (Abramowicz 1979, 128-129; zob. także Reitinger 1976, 522; Bagley 2015, 198-199).

Taka wykładnia określała postrzeganie rozpatrywanych artefaktów w średniowieczu. Marbod, biskup Rennes (zm. 1123), w wierszowanym dziele Liber Lapidum seu de Gemmis, napisanym między 1061 a 1081 rokiem, omówił medyczne i magiczne właściwości kamieni, uwzględniając także rozpatrywane tu znaleziska ${ }^{22}$. Według niego spadające $\mathrm{z}$ nieba kamienie

20 Zob. przyp. 3-6.

21 Est inter candidas et quae ceraunia vocatur, fulgorem siderum rapiens, ipsa crystallina, splendoris caerulei, in Carmania nascens. Zenothemis fatetur albam esse, sed habere intus stellam concursantem [...]. Sotacus et alia duo genera fecit cerauniae, nigrae rubentisque; similis eas esse securibus; ex his quae nigrae sint ac rotundae sacras esse, urbis per illas expugnari et classis, baetylos vocari; quae magorum studiis expetitam, quoniam non alibi inveniatur quam in loco fulmine icto (C. Plinii Secundi, Naturalis Historiae, XXXVII, 51, s. 436).

22 Mając na względzie biografię i konfesję religijną autora, na podkreślenie zasługuje ton utworu o wyraźnie 
piorunowe chroniły człowieka, a także jego domostwo przed uderzeniem pioruna. Tak samo sprawdzały się podczas podróży rzecznej lub morskiej. Przyczyniały się ponadto do zwycięstw w bitwach oraz zapewniały dobry $\operatorname{sen}^{23}$.

Relacja Marboda prawdopodobnie posłużyła jako podstawa rozdziału o kamieniach piorunowych w duńskim lapidarium, przypisywanym kapłanowi Henrikowi Harpestraengowi, kanonikowi katedry w Roskilde (zm. 1244 r.). W ten sposób kontynentalne tradycje przypuszczalnie przyczyniły się do rozpowszechnienia wiary w nadprzyrodzone pochodzenie kamieni piorunowych i ich właściwości magiczne na terenach północnoeuropejskich (Carelli 1997, 402).

$\mathrm{W}$ podobnym tonie wypowiadał się Albert Wielki (zm. 1280). W rozprawie De mineralibus et rebus metallicis libri quinque podał, że Ceraunius lapis esse fertur cristallo similis, infecto colore caeruleo, qui dicitur cadere aliquando de nube cum tonirruo et inuenitur in Germania et Hisp[a]nia: sed Hispan est candes ut ignis, puocat dulces somnos ut dicunt, et prelia et caussas vincendi et contra periculum tonitrui dicitur operari (II, 3, s. 127; por. przekład w Albertus Magnus, Book of Minerals, II, 3, s. 79).

Mniej więcej stulecie później Konrad von Megenberg (zm. 1374), niemiecki uczony i pisarz, w Księdze Natury (Buch der Natur) zanotował, że pochodzący $\mathrm{z}$ nieba kamień piorunowy (dornstein) powinien chronić miejsce, w którym aktualnie się on znajduje (Konrad von Megenberg, Buch der Natur, ks. VI (21), s. 441; zob. Franz 1909, 41).

W okresie renesansu, dalej pod wpływem przekazów antycznych, omawiane znaleziska nadal powszechnie uważano za przedmioty spadające $\mathrm{z}$ nieba podczas burz. Już jednak pod koniec XVI w. włoski przyrodnik Michele Mercati (zm. 1593) w dziele Metallotheca vaticana wysunął tezę, w myśl której ceraunia są narzędziami wykonanymi przez człowieka. Do tej nowatorskiej konkluzji doszedł jako kurator watykańskiego ogrodu botanicznego, gdzie był odpowiedzialny za poszerzającą się kolekcję historii natu-

pogańskim zabarwieniu, tylko w niewielkim stopniu odnoszącym się do chrześcijańskiej symboliki (Schuh 2007, 43).

23 Qui caste gerit hunc, a fulmine non ferietur, Nec domus aut villae, quibus affuerit lapis ille. Sed neque nauigio per flumen vel mare vectus, Turbine mergetur, vel fulmine percutietur. Ad caussas etiam, vincendaque proelia prodest, Et dulces somnos, et dulcia somnia praestat (Marbodi Liber Lapidum seu de Gemmis, 28, s. 56). ralnej, która obejmowała skamieniałości oraz liczne materiały etnograficzne pochodzące z Nowego Świata. To dzięki analizie tych danych Mercati zauważył, że ceraunia $\mathrm{z}$ istniejących kolekcji bardzo przypominają niektóre kamienne wyroby wykonane przez ludy obu Ameryk. To podobieństwo doprowadziło go do wniosku, że wytworów tych używano jako broni lub narzędzi (Goodrum 2002, 257-258; Goodrum 2008, 493-497). Badacz ten wyróżnił dwie grupy znalezisk w uwzględnionym w swoich dociekaniach materiale. W pierwszej znalazły się przedmioty, które niewątpliwie należy uznać za neolityczne narzędzia (ceraunia cuneata), a do drugiej zaliczone zostały wyroby krzemienne, głównie groty strzał (ceraunia vulgans) (Mercati 1717, 241-245; zob. Gaudant 2007, 105-108, ryc. 5-6; Cardoso, Gonçalves 2020, 111, ryc. $7-8)$.

Warto jednak podkreślić, że dokonania włoskiego uczonego nie były publikowane aż do początku XVIII w. (praca ta ukazała się drukiem dopiero w 1717 r.), a zatem trudno określić ich reperkusje w ówczesnym dyskursie prowadzonym wokół genezy ceraunii. Zapewne wpływ ten był niewielki, zważywszy na to, jak opornie przebijała się myśl o kamieniach piorunowych jako wytworach ludzkiej ręki, których nie należy łączyć $\mathrm{z}$ niebiańskim czy geologicznym pochodzeniem, wykazującym związek z wyładowaniami atmosferycznymi w czasie burzy ${ }^{24}$. Tym samym znaleziska paleontologiczne i archeologiczne w ówczesnych zapatrywaniach na świat funkcjonowały w sposób nie mający nic wspólnego z ich rzeczywistym znaczeniem. Były one gromadzone przez przyrodników i starożytników jako kamienie, które swą unikalną formę osiągnęły w wyniku poniekąd naturalnego procesu - powstawały, gdy błyskawica trafiała w ziemię. Dopiero w końcu XVII i XVIII w. niektórzy uczeni zaczęli powszechniej kwestionować taką genezę kamiennych wyrobów pradziejowych i wysuwać argumenty na rzecz właściwej ich interpretacji. W efekcie postępującej dyskusji i rozwoju nauki utrwaliło się przekonanie, że w dziejach Europy istniał okres, gdy jej mieszkańcy wytwarzali i w rozmaity sposób posługiwali się narzędziami kamiennymi ${ }^{25}$.

24 Tylko nieliczni uczeni byli wprowadzeni w idee Mercatiego, w tym duński anatom i geolog Nicolaus Steno (zm. 1686), który w 1667 r. wykorzystał jedną z ilustracji dzieła włoskiego badacza (Høiris 2015, 8).

25 Na temat rekonceptualizacji kamieni piorunowych w nowożytnych dziejach nauki zob. zwłaszcza Abramowicz 1979, 128-150; Lech 1992, 268-269; Jensen 1999; 
Pomimo wyjaśnienia kwestii pochodzenia kamieni piorunowych, odkrycia naukowe nie miały żadnego wpływu na powszechne przekonanie o piorunach w kulturze ludowej, w której wiara w magiczną moc tych przedmiotów utrzymywała się znacznie dłużej, czego wyrazem są przekazy folklorystyczne z XIX i początku XX w. W dalszym ciągu nie zdawano sobie sprawy, iż są to wyroby wykonane przez człowieka, liczyło się natomiast ich nadprzyrodzone pochodzenie (zob. Mehling 1998, 113).

\section{Magiczna ochrona zabudowań przed piorunem, pożarem i innym złem}

Ze względu na wywodzenie kamieni piorunowych ze sfery niebiańskiej zrozumiały staje się fakt, że ich podstawowa funkcja polegała na ochronie przeciw piorunom i niszczycielskim skutkom burzy. Obsadzenie w tej roli omawianych wytworów jest głęboko zakorzenione w przeszłości i obserwowane w wielu kulturach, mając niemal globalny zasięg. Wynikało to z nadrzędnej zasady, że piorun nigdy nie trafiał dwukrotnie w to samo miejsce. Wierzono tym samym, iż kamień piorunowy znaleziony w miejscu uderzenia przez piorun i zabrany do domu zapobiega konsekwencjom pojawienia się burzy (np. Blinkenberg 1909, 70; Olbrich 1927, 327; Muhonen 2006, 8; Belaj 2007, 118; Verhart 2015, 84). Kierowano się zasadą, iż tam, gdzie jest jeden z nich, inne już nie spadną (Pedrosa 2009, 262, 267, 269; Rúa Aller, García Armesto 2010, 65). Uznawany powszechnie jako skuteczny środek przeciwogniowy, miał zatem zapewniać ochronę i bezpieczeństwo domownikom i ich dobytkowi (Carelli 1997, 404).

Znaczenie profilaktyczne przypisywane omawianym przedmiotom sprowadza się tym samym do dwóch kierunków interpretacyjnych, niekoniecznie przeciwstawnych. Pierwszy z nich opiera się na powszechnym przekonaniu wykluczającym powtórzenie się przypadkowego zdarzenia w odniesieniu do tego samego miejsca i obiektu, co oznacza, że obecność kamienia piorunowego niweluje działanie pioruna. Drugi znajduje oparcie w swego rodzaju homeopatycznej mocy samego kamienia, którego zamknięta energia pochodząca z błyskawicy może być skierowana przeciwko niej samej i innym nieszczęściom

Goodrum 2002; Goodrum 2008; Goodrum 2011; Gaudant 2007; Pedrosa 2009; Meinecke 2014; Høiris 2015; Sklenář 2018, 30-31; Cardoso, Gonçalves 2020.
(Cherici 1989, 373-374). Mielibyśmy tu tym samym do czynienia z zasadą, że ,podobne chroni przed podobnym".

Tym samym uzasadnionym posunięciem było umieszczanie przedmiotów uznanych za kamienie piorunowe w różnych punktach domu i zabudowań gospodarczych, a także murów miejskich i fortyfikacji, nie wyłączając budynków sakralnych, zarówno chrześcijańskich, jak i pogańskich ${ }^{26}$. Zapewne w pierwszej kolejności starano się zabezpieczyć przestrzeń najbardziej narażoną na uderzenie przez piorun i w efekcie pożar, a mianowicie dach z jego kulminacyjnym elementem - kominem. Stąd, jak pokazano wcześniej, bardzo częsta obecność wyrobów pradziejowych w tych właśnie miejscach (ryc. 19) (zob. Heidelk-Schacht 1983, 108). Zarazem przedmioty te starannie ukrywano we wnękach ścian i pod podłogami, co zapewniało objęcie ich mocą wszystkich liminalnych lokalizacji w domostwie i obejściu (Dowd 2018, 465), które, jak obrazowo wypowiedział się B. Hoggart, stanowiły part of the spiritual armoury of the house (Hoggart 2004, 182).

Szczególnie newralgicznym miejscem był próg wyznaczający linię graniczną między przestrzenią wewnętrzną, oswojoną, a tym, co zewnętrzne, nieprzyjazne. W tym sensie wymagał specjalnej ochrony i działań zabezpieczających przed ingerencją zła (Kowalski 1998, 480-485). Stąd zwyczaj umieszczania kamieni piorunowych pod progami. Ulokowany tam przynosił szczęście człowiekowi i domowi, broniąc przed piorunem (Laurinkienè 1996a, 26; Laurinkienè 1996b, 112). W Finlandii wierzono, że kamień piorunowy stanowił skuteczną zaporę przed czarami, wiedźmami lub po prostu pełnił rolę „strażnika”. W takim charakterze ukrywano go pod progiem obory, tak aby czarownice nie mogły go przekroczyć, aby szkodzić bydłu (Hukantaival 2016, 183-184; 2019, 348). Podobnie postępowano w Czechach. Gdy stwierdzono szkodliwą działalność wiedźm, gospodynie zakopywały kamienie piorunowe pod progami obór w naczyniach glinianych. Ważne było, aby nikt ich przy tym nie widział, w przeciwnym razie cała operacja traciła swą skuteczność (Skutil 1932, 36; zob. także Tolstoy 1995, 562). Kilka przykładów takiego ulokowania omawianych znalezisk, potwierdzonego archeolo-

26 Siekiera kamienna znaleziona w Hedeby interpretowana jest jako ofiara bóstwa piorunowego dla ochrony budowli (wielkiej hali) przed burzą i pożarem (ryc. 6:3) (Paulsen 1939, 190). 
gicznie już dla średniowiecza, podano w przeglądowym ich zestawieniu.

Wiadomo również, że gdy nadciągała burza kamień piorunowy często był po prostu stawiany na stole bądź na palenisku i tym prostym sposobem starano się ją odegnać. W hiszpańskiej tradycji chłopskiej, np. z rejonu León, umieszczony w oknie lub w innym widocznym miejscu, obok płonącej poświęconej świecy, powodował, że niebezpieczna chmura gradowa zamieniała się w nieszkodliwy i korzystny deszcz (Pedrosa 2009, 261, 263, 265; Rúa Aller, García Armesto 2010,65$)^{27}$. Takie same środki podejmowano m.in. w Westfalii (Andree 1889, 33). Ze Śląska znany jest przypadek, gdy świecę umieszczono bezpośrednio w otworze na toporzysko i w ten sposób kamienny topór pełnił funkcję stawianego na stole świecznika (Sklenář 1999, 52). Natomiast w prowincji Salamanca dla odegnania burzy wkładano kamień piorunowy do ognia i wynoszono za drzwi domu, aby zgasiła go woda deszczowa (Pedrosa 2009, 268). W Czechach przy zażegnywaniu pożaru kamienia piorunowego nie wolno było brać w gołą rękę, lecz tylko przez płótno (Hraše 1898, 83; zob. także Hammarstedt 1925, $445)^{28}$. Na Mazurach w czasie zbliżającej się burzy wkładano palec do otworu kamiennego topora i wypowiadając zaklęcia obracano trzykrotnie, a następnie

27 Należało przy tym pamiętać o tendencji powrotu do chmur takich kamieni, zwłaszcza gdy grzmiało. Aby tego uniknąć, we wsiach pirenejskich wykonywano z boku nacięcie lub umieszczano na nich cięższy kamień (Pedrosa 2009, 264).

28 Nosiłoby to pewne znamiona działań o podłożu tabuistycznym, ujawniających respekt wobec omawianych przedmiotów. Stąd starano się je przechowywać w miejscach odosobnionych i ograniczać bezpośredni z nimi kontakt(Blinkenberg 1911,33; Ellis Davidson 1965, 6). Zdarzało się nawet, iż w obawie przed nieszczęściem powstrzymywano się przed dotykaniem kamieni piorunowych (tak w niektórych rejonach Kalabrii we Włoszech - Lovisato 1878, 504; Larocca, Breglia 2016, 301). Zbliżałoby się to do obserwowanych niekiedy zachowań ukierunkowanych na pozbywanie się takich przedmiotów. Po znalezieniu były one albo natychmiast głęboko zakopywane (południe Żyrondy we Francji), albo zupełnie niszczone (Derbyshire na Wyspach Normandzkich), co miało odeprzeć złe oko i zapobiec nieszczęściu (Cartailhac 1878, 22-23; Saintyves 1936, 173). Zaobserwowano także, iż w rejonie Bergerac w departamencie Dordogne (Francja) znalezione polerowane siekiery chłopi łamali na dwie części, aby odebrać im tajemną moc, a następnie wyrzucali (Saintyves 1936, 152). Podobnie w niekórych częściach Owerni, gdzie przynosiły pecha. Stąd należało je rozbić na jak najwięcej kawałków i natychmiast się ich pozbyć (Saintyves 1936, 160). rzucano nim z całej siły w drzwi izby (Toeppen 1867 , 42; Moszyński 1967, 488; Olbrich 1987, 327). Bardzo podobne zachowania obserwowano też na ziemi sieradzkiej (Wdowiak, Wysokiński 2013, 535).

Podejrzewa się, że w każdym domu w północnej Europie znajdował się topór lub inne pradziejowe narzędzie, które trzymano dla odpędzenia katastrofy (Verhart 2015, 84). Podobnie wypowiadano się w odniesieniu do terenu Słowacji (Klecanda 1901, 214), Moraw (Koudelka 1882, 159), Niemiec (Andree 1889, 32), Francji (Cartailhac 1878, 19) czy Hiszpanii (Pedrosa 2009, 261). Wydaje się to adekwatne dla większości rejonów kontynentu europejskiego, zwłaszcza obszarów wiejskich.

W krajach północnoeuropejskich (Szwecja, Finlandia) omawiane kamienie piorunowe wykorzystywano jako swoisty środek przeciwpożarowy. Uważano, że pożar nie wydostanie się poza obszar, wokół którego przemieszczano się $\mathrm{z}$ toporem lub innym pradziejowym narzędziem z kamienia (np. Kjellmark, Thordeman 1939, 80; Muhonen 2006, 8) ${ }^{29}$.

Częste ukrywanie kamieni piorunowych w przestrzeni związanej z ogniem, jak paleniska, kominy czy piece, mogło wynikać nie tylko z faktu, że były to miejsca dostępu dla sił negatywnych, ale też z pozytywnymi skojarzeniami koncentrującymi się wokół nich (ognisko domowe), a stąd kluczowego znaczenia dla domu i rodziny, zarówno w sensie dosłownym, jak i metaforycznym. Tym samym nie tylko potrzeba oddalenia zła, ale też zachowanie tego, co dobre i pomyślne, decydowało o powyższej lokalizacji omawianych obiektów (szerzej zob. Houlbrook 2019, 196197). Z kultem ognia wiązany jest topór znaleziony w Gdańsku. Uważa się, iż pozostawiono go celowo na palenisku po opuszczeniu domostwa. Musiał to być ważny moment $\mathrm{w}$ życiu rodzinnym, stąd starania, aby do rozstania ze starym ogniskiem doszło we właściwy i przewidziany rytualnie sposób (Lepówna 1981, 180, 194).

Pomijając umiejscowienie w obrębie domostwa czy innego rodzaju zabudowań, trudno byłoby stwierdzić na podstawie samych tylko cech przedmiotu, czy pełnił on opisaną wyżej funkcję ochronną. Warto jednak wspomnieć o toporze z Mellenau znalezionym w piecowisku, którego krawędź tnąca została celowo odcięta i tępo wygładzona (ryc. 4:2) (HeidelkSchacht 1983, 107). Według interpretacji zapropo-

29 Takie zastosowanie miały okazy z Entsebo i Huskölen w Szwecji (ryc. 10:11-12) (Hammarstedt 1920, 15, 16, ryc. 12,18$)$. 
nowanej przez S. Heidelk-Schacht przeprowadzenie takiego zabiegu miało uczynić piorun nieszkodliwym (Heidelk-Schacht 1983, 108). Tym niemniej wypada zauważyć, że wiele okazów nie wykazywało śladów podobnego potraktowania, a do uszkodzenia mogło dojść podczas pierwotnego użytkowania przedmiotu. Niekiedy nawet w charakterze kamienia piorunowego wykorzystywano samą krawędź tnącą, jak w przypadku siekiery z Zitternberg (ryc. 7:2) (Maurer 2012, 241).

\section{Kamień piorunowy jako ofiara zakładzinowa (?)}

Składanie kamieni piorunowych w fundamentach, piwnicach, pod podłogami, progami czy słupami nosi pewne znamiona ofiary zakładzinowej. Tak zinterpretowano topór z Gnoien (Heidelk-Schacht 1983, 107). Dokładna lokalizacja przedmiotu w przestrzeni domostwa nie została jednak ustalona, co stawia pod znakiem zapytania przypisanie mu takiej funkcji.

Bardziej wiarygodne wydaje się to w przypadku innych okazów, którym towarzyszyły znaleziska często wykorzystywane jako zakładziny. W Pockau pod podłogą natrafiono topór, a obok niego (około 50 $\mathrm{cm}$ ) znajdowało się naczynie gliniane (ryc. 5) (Geupel 1987, 2-3). W świetle zapatrywań V. Geupela charakter i okoliczności odkrycia powyższy zespół znalezisk można uznać za ofiarę zakładzinową, jakkolwiek z dalszych wywodów wynika, iż sam topór (podobnie jak inne opisane wyroby) pełnił funkcję typowego kamienia piorunowego (Geupel 1987, 3). Drugi przykład mamy z zamku Ketzelburg w Haibach. W obrębie fundamentu wieży mieszkalnej zalegał szkielet psa, starannie przykryty kilkoma kamiennymi płytami i warstwą zbitej ziemi. Nieopodal (pod murem) znaleziono neolityczne narzędzie. Obiekty te mogły zostać celowo zdeponowane w czasie budowy warowni. W opinii G. Ermischera: Die Kombination von Hund und Steinbeil [chodzi o narzędzie w kształcie kopyta szewskiego - TK] gibt auch einen Hinweis auf die wahrscheinlichste Interpretation des Fundes: es handelt sich hier um „Bauopfer", die Unheil von dem Gebäude abhalten sollten (Ermischer 2006, 99). Wprawdzie na kościach nie stwierdzono śladów celowego uśmiercenia psa, nie wyklucza to jednak jego wyboru na ofiarę (Ermischer 2006, 100-102).

Wydaje się, iż deponowanie omawianych przedmiotów w charakterze zakładziny, jeśli w ogóle miało miejsce, było praktykowane incydentalnie. Opisane wyżej znaleziska należy traktować jedynie jako hipotetyczne przypadki takiego zastosowania kamieni piorunowych.

\section{Magiczne moce kamieni piorunowych: płodność, urodzaj, pomyślność}

Przeświadczenie, że kamienne wyroby pradziejowe wykazują właściwości ochronne przełożyło się na przypisanie im ogólnie dobroczynnego wpływu na domostwo z całym jego inwentarzem. Szczęśliwego znalazcę kamień piorunowy zabezpieczał nie tylko przed burzą, ale też przed chorobami, urokami, zmorami i wszelkim złem. Noszono go zatem jako osobisty amulet. Na Pomorzu wieszano go sobie na piersi (Olbrich 1987, 327). We wsi Vrbno (Chorwacja) opisano przypadek noszenia na szyi masywnego kamiennego topora dla ochrony przed „karą boską" (Šimek 2010, 141; Burić 2015, 356). W celu odpędzenia diabła kamienie piorunowe wkładano do kieszeni na Litwie (Laurinkiené 1996a, 26; Laurinkienè 1996b, 112). W taki sposób starano się odpędzić burzę w Bretanii, wypowiadając odpowiednio sformułowane zaklęcia bądź modlitwy, np.: „Pierre, pierre, garde-moi de tonnerre" (Sébillot 1904, 104-105; Saintyves 1936, 119). W kieszeniach kamienie piorunowe noszone były też w Hiszpanii, aby mieć bezpośredni i nieprzerwany kontakt $\mathrm{z}$ magiczną mocą. Tam też, po wykonaniu otworu, wieszano je sobie na szyi (García Castro 1988, 438; Pedrosa 2009, 263, 267) bądź, jak w prowincji Guadalajara, trzymano w zawiązanych na końcu rękawach pasterskiego okrycia wierzchniego zwanego anguarina (Alonso Ramos 1993, 158). Podać też można również przykład muzułmańskiego starszego z jednej z wiosek z okolic Bihaća (Bośnia i Hercegowina), który nosił niewielki neolityczny kamienny topór zatknięty za pasem (Sielski 1941, 111112, ryc. 30). Znaleziska neolitycznych kamiennych strzał i kamiennych toporów używanych jako amulety odnotowano w Karahodže niedaleko Travnika (Bośnia i Hercegowina) jeszcze w pierwszej połowie XX stulecia (Sielski 1941, 112). W XIX w. dla ochrony przed burzą kamienie piorunowe zabierane były na statki (Cartailhac 1878, 17; Baudouin, Bonnemère 1904, 498; Sébillot 1904, 104).

W powyższym kontekście na uwagę zasługują okazy pochodzące ze średniowiecznych nawarstwień Nowogrodu Wielkiego z wtórnie wykonanymi otworami, w celu zawieszenia przedmiotu (ryc. 16:4) (Musin et al. 2018, 31, ryc. 10:a). Wielkość niektórych oka- 
zów sugeruje też, że wieszano je w obrębie domostwa (ryc. 16:8) (Tyanina 2018, 67-68, ryc. 6:g). Wskazywać na to może także wykonanie otworów w połowie długości przedmiotu. Perforację stwierdzono też na wymienionych wcześniej okazach, m.in. z Hønborggård (ryc. 10:13) i Develier-Courtételle (ryc. 12:7). Ten ostatni to niewielki fragment przerobiony na zawieszkę (Rebmann 2006, 138, 308, tabl. 64:4). Do noszenia przystosowane były także niektóre pradziejowe wyroby z wyrytymi znakami i symbolami religijnymi, o których mowa będzie w dalszej części pracy.

Innego rodzaju ślady zaobserwowano na neolitycznym siekieromłocie ze wzgórza zamkowego w Devinie. Są to obustronnie wygładzenia o trójkątnym zarysie widoczne na krawędziach otworu na toporzysko (ryc. 3:6). Uważa się, iż jest to efekt długotrwałego zawieszenia na sznurku z jakiegoś miękkiego materiału organicznego (Farkaš, Gregor 2016, 35 , ryc. 2). Z uwagi na wielkość (ponad $9 \mathrm{~cm}$ ) trudno stwierdzić, czy był to osobisty amulet. Autorzy skłonni są raczej wiązać przedmiot ze zwyczajem znanym głównie z regionów niemieckojęzycznych wieszania kamieni piorunowych na drzewach (zob. Skutil 1932, 45). Podobne ślady powstałe po zawieszaniu na sznurku ma też dłuto z Zelenej Lipy (Pyvovarov 2008, 108).

Jako ciekawostkę warto także przywołać niewielkie egzemplarze $\mathrm{z}$ otworami przy obuchu znane $z$ terenu Francji. Wykonano je $z$ większych i starszych okazów wykonanych z eklogitu i jadeitu, przy czym trudno dokładnie ustalić, kiedy doszło do przerobienia ich w amulety-zawieszki (Giligny et al. 2012, 1142, ryc. 12)

Do rozpatrywanej kategorii wierzeń w kamienie piorunowe nawiązuje obserwowane u Estów i Słowian uderzanie się nimi w głowę po usłyszeniu pierwszego wiosennego grzmotu. Panowało przekonanie, iż potarta nimi głowa będzie twarda jak kamień, a osoba bezpieczna od piorunów (Moszyński 1967, 489; Valentsova 2018; zob. także Andree 1889, 3435; Skutil 1932, 37).

Kamienie piorunowe znajdowały zastosowanie także w innych sytuacjach wymagających magicznego wsparcia. W Niemczech panowało przekonanie, że gdy myśliwy umieści cząstkę takiego znaleziska w formie do odlewania kul, zwierzyna będzie padać jak rażona piorunem (Olbrich 1987, 327). W wielu rejonach europejskich (np. Dolna Saksonia, Hesja, Szkocja, Szwecja, Czechy) omawiane przedmioty dawano do ręki rodzącym kobietom dla ułatwienia po- rodu $^{30}$, a także będącym w połogu (Cartailhac 1878, 21; Barner 1957, 176; Penney 1976, 72; Reitinger 1976, 534; Olbrich 1987, 328; Sklenáŕ 1999, 46) 31. Wyroby pradziejowe wkładano też do kołysek dziecięcych, prewencyjnie albo w razie choroby (np. Cartailhac 1878, 21; Moszyński 1967, 488; Sklenáŕ 1999, 46), a także dla ochrony przed burzą (Toeppen 1867,42 ) (2. $^{32}$. W Szwecji wieszano je na szyi małych gorączkujących dzieci, a jeden z takich okazów (z Lilla Ånhult, Smalandia) opublikował N.E. Hammarstedt (1920, 14, ryc. 11) (ryc. 10:5). Dla zachodniej Rumunii (Vlădești) odnotowano, że do zatamowania krwotoku z nosa stosowany był kamień przebity przez piorun, a więc najpewniej kamienny topór. Wystarczyło wówczas przez otwór przelać trzy krople krwi (Ciubotaru 2002-2003, 198). W Chorwacji kamienna strzała umieszczona w wodzie, którą należało wypić trzykrotnie, uwalniała od zaklęcia (Šimek 2010, 142).

Szeroki zakres zabiegów magicznych związanych z kamiennymi artefaktami o dawnej metryce uwzględniał także dobro hodowlanych zwierząt i uprawianych roślin. Miały one za zadanie chronić je przed chorobami, jak również zapewnić płodność i urodzaj.

W Czechach kliny piorunowe umieszczano w stodołach w celu zabezpieczeniu ziarna (Fröhlich 1992, 240). W rejonie jeziora Kenozero (północna Rosja) umieszczano kamienne narzędzia w nasionach rzepy dla ochrony przed zepsuciem (Kharuzin 1894, 341). W takim charakterze używano siekiery z Uppsali (ryc. 10:6). Włożona w ziarno jęczmienia miała gwarantować, że jego zasoby nigdy się nie skończą (Hammarstedt 1920, 15, ryc. 13). Na Śląsku, w Szwecji i Finlandii chłopi wkładali kamienie piorunowe w ziarno podczas siewu, aby uzyskać dobre plony (Hammarstedt 1925, 445; Skutil 1932, 43; Olbrich 1987, 327). Rozpowszechniony był również zwyczaj ich rozrzucania i zakopywania na polach uprawnych (Niemcy, Skandynawia, Czechy), co z jednej strony miało

30 W El Bierzo i Galicji (Hiszpania) w tym celu kamień piorunowy przywiązywano do lewej nogi, a dla spowolnienia porodu - do lewej ręki (Rúa Aller, García Armesto 2010, 66).

31 Położnice niekiedy posypywano zeskrobanym z przedmiotu proszkiem, aby wróciły do pełni sił (Hraše $1898,83)$. Dawano im niekiedy do picia wodę ze sproszkowanym kamieniem lub w której taki kamień uprzednio się znajdował (Moszyński 1967, 488; Plessingerová, Vařeka 1999, 211).

32 W Danii w kamienne topory zaopatrywano dzieci nieochrzczone (Ellis Davidson 1965, 11). 
zapewniać plenność roślin, z drugiej zaś chronić je przeciw pożarom i gradem (Skutil 1932, 43; Sklenár 1999, 56; tam starsza literatura). W niektórych regionach Francji już samo znalezienie tych przedmiotów na polu było zapowiedzią dobrych zbiorów i zabezpieczeniem upraw przed mrozem (Ribon 1993, 132). Z myślą o pomyślności kamienie piorunowe, zwłaszcza $w$ regionach niemieckojęzycznych wieszano na drzewach owocowych (Boges 1910, 8; Skutil 1932, 45), głównie chorych i usychających (Olbrich 1987, 327). W Szwecji (Värmland) kamiennych siekier używano także jako ciężarków do sieci, z myślą o obfitszym połowie (Cartailhac 1878, 21; Saintyves 1936, 228). Tam też trzymano kamienie piorunowe w mące w przeświadczeniu, że za ich sprawą jedzenie nigdy się nie skończy, np. fragment ostrza z parafii Skepptuna w pobliżu Sigtuny (ryc. 10:7) (Hammarstedt 1920, 15 , ryc. 14). Na dawnych terenach Rzeczypospolitej za sprawą kamieni piorunowych włożonych do dzieży ciasto wyrastało i chleb się udawał (Biegeleisen 1929, 343). Miały one za zadanie zabezpieczać żywność (np. mleko) przed zepsuciem, jak fragment topora z parafii Ökna w pobliżu Vetlandy w Szwecji (ryc. 10:8) (Hammarstedt 1920, 16-17, ryc. 19).

W Bretanii pradziejowe wyroby z kamienia były często wrzucane do studni w celu oczyszczenia wody lub zapewnienia jej stałej tam obecności (Cartailhac 1878, 20; Evans 1897, 57; Saintyves 1936, 120; Merrifield 1987,13$)^{33}$.

W wielu rejonach europejskich (np. w Hesji) cielętom dawano wodę z poidła, w której leżał kamienny topór. Wkładano go także do koryta z paszą i mlekiem dla prosiąt. Czyniono tak z przeświadczeniem, że zwierzęta będą się lepiej chowały (Barner 1957, 177; zob. także Beuker 1997, 23). Z kolei w Finlandii kamień piorunowy umieszczony w poidle chronił krowy przed błyskawicami (Muhonen 2006, 9). Wieszanie ich w oborach w hiszpańskich wsiach traktowano jako skuteczny bodziec do rodzenia się jałówek, co z hodowlanego punktu widzenia oceniano jako bardziej korzystne (Blas de, Maya 1974, 213; Pedrosa 2009, 265, 266; Aguirre Sorondo 2013, 141). W prowincji León (Fresno de la Vega) odnotowano zwyczaj polegający na pozostawieniu przy strzyżeniu koni, klaczy i osłów części grzywy pod kamieniem piorunowym w niszy ściennej. Tłumaczy się to dobroczynną jego mocą, która mogła służyć ochronie zwierząt lub

33 W tamtejszym departamencie Côtes-d'Armor wierzono, że woda z takiej studni użyta do pojenia bydła, chroniła je przed niektórymi chorobami (Saintyves 1936, 117). dawać im siłę utraconą na skutek obcięcia sierści (Rúa Aller, García Armesto 2010, 66). W okolicach Dinan (Bretania) wkładano siekiery do gniazd kurzych, aby zapewnić lepszy lęg (Saintyves 1936, 118). Natomiast w dawnej południowofrancuskiej prowincji Rouergue pasterze chronili zwierzęta przed niebezpieczeństwem, a zwłaszcza przed porażeniem przez piorun, zawieszając kamienną siekierę w dzwonku owcy, będącej przewodnikiem stada (Baudouin, Bonnemère 1904, 498; zob. także Saintyves 1936, 144, 151, 152, $160,165,168,169)$.

Jeśli krowa dawała mleko z krwią, dojono ją przez otwór w kamiennym toporze (Toeppen 1867 , 42, 100; Cartailhac 1878, 19-20; Bartels 1893, 559; Biegeleisen 1929, 344; Olbrich 1987, 327) 34. Praktyki te zostały potępione przez węgorzewskiego pastora Georga Helwinga w dziele Lithographia Angerburgica z 1717 r. (Helwing 1717, cap. VII, sectio 1, § 4, s. 85; zob. Abramowicz 1979, 144; Łapo 2008, 23; Szczepański 2010, 9-10). Na ziemiach polskich czyniono tak również, aby krowy dawały dużo wysokojakościowego mleka (Biegeleisen 1929, 343). W Chorwacji w powyższy sposób przepuszczano mocz chorego zwierzęcia, wypowiadając przy tym zaklęcia (Šimek 2010, 141-142).

Przypuszczalnym świadectwem prób leczenia, w których kluczowe znaczenie przypisywano otworowi na toporzysko, może być topór znaleziony w Pockau (Saksonia) pod podłogą sieni domu z 2. połowy XVII w. Wykonano go z większego, złamanego egzemplarza (ryc. 5:1). Wskazuje na to nieregularna i powierzchowna obróbka oraz nowy otwór w miejsce poprzedniego, jeszcze częściowo widocznego (Geupel 1987, 2-3, ryc. 1:b). Do tej tak ważnej, jak się wydaje, przeróbki lub naprawy mogło dojść w niedługim czasie przed zdeponowaniem. Byłoby to spostrzeżenie o tyle istotne, gdyż wierzono, że otwór do umocowania trzonka powstał na skutek uderzenia pioruna, stąd kamień przejawiał większą moc magiczną (Sklenář 1999, 25; Hložek et al. 2015, 272).

34 Na terenie Prus Wschodnich sądzono, że takie zwierzę miało verhekste Milch (Andree 1889, 32). W odniesieniu do Moraw mowa jest także o używaniu kamieni piorunowych, gdy ,zauroczona” krowa dawała niebieskie mleko (blaue Milch) (Koudelka 1882, 160). Niekiedy, tak jak w Rumunii, na Węgrzech czy w Czechach (XVIII-XIX w.), należało wydoić ją przez topór lub potrzeć nim wymię, żeby utracone na skutek czarów mleko w ogóle przywrócić (Šimek 1909, 458, 459; Hála 2016a, 44; Ofrim 2019, 93-94). 
Nie tylko kształt czy wielkość omawianych przedmiotów przyciągały uwagę znalazców i miały wpływ na magiczną ich skuteczność. Liczyły się także inne cechy - barwa i połysk. W niektórych regionach Hiszpanii szczególnie cenne i poszukiwane były czarne neolityczne siekiery (rayos negros), gdyż zdolne były przyciągać szczęście i obdarzać znalazców fortuną (García Castro 1988, 440; Rúa Aller, García Armesto 2010, 66-67). Czerwone zabarwienie fragmentarycznie zachowanego kamiennego oręża odkrytego w XIX w. w pobliżu cmentarza w Jokioinen (Finlandia) i używanego jako kamień piorunowy również zwiększało magiczną moc przedmiotu. Było to podyktowane rzadkością takiej kolorystyki wśród tego rodzaju znalezisk (Hukantaival 2019, 354, 374).

\section{Znaki, napisy i symbole}

Posługując się kamieniami piorunowymi, podejmowano zabiegi mające podnieść ich skuteczność magiczną. Należy sądzić, że ich wartość sakralną podkreślały, wzmacniały i wspomagały różnego rodzaju symbole i przedstawienia wykonane w znacznie już późniejszych realiach chronologiczno-kulturowych. Już z czasów antycznych pochodzą neolityczne narzędzia kamienne, $\mathrm{z}$ naniesionymi greckimi inskrypcjami, znakami i wyobrażeniami o wymowie modlitewno-magicznej i apotropaicznej. Znaleziska te miały umożliwiać i ułatwiać kontakt $\mathrm{z}$ bóstwami lub demonami oraz stanowić ochronę przeciw niszczycielskiemu piorunowi i rękojmię triumfu (zob. Quast 2011; Faraone 2014).

Magiczne użycie toporów, młotów i cioseł neolitycznych potwierdzają okazy pokryte ornamentyką romańską (ryc. 20) (Montelius 1906, 67, ryc. 100), a zwłaszcza te z naniesionymi inskrypcjami runicznymi, które odnotowano w krajach skandynawskich (Rafn 1854; Way 1868, 117; Cartailhac 1878, 34-35, ryc. 18-20; Blinkenberg 1911, 84, 91; 1988, Snædal et al. 1988, 247-249, ryc. 12-13; Horn Fuglesang 1989, 22; Grünzweig 2004, 157-159; Grønbeck 2016; Søyland 2017, 55-56, 267-268, ryc. 20). Takie napisy pozwalają sądzić, iż mamy do czynienia $\mathrm{z}$ amuletami (Wessman 2009, 77). W niektórych przypadkach były to imiona własne, np. na okazie z Upplandii z napisem, który tłumaczony jest następująco: Oltha posiada ten topór (ryc. 21:1) (Montelius 1906, 67, ryc. 99; Holtfort 2015, 81), przez co przypuszczalnie amulet zapewniał posiadaczowi większą ochronę (Quast 2011,

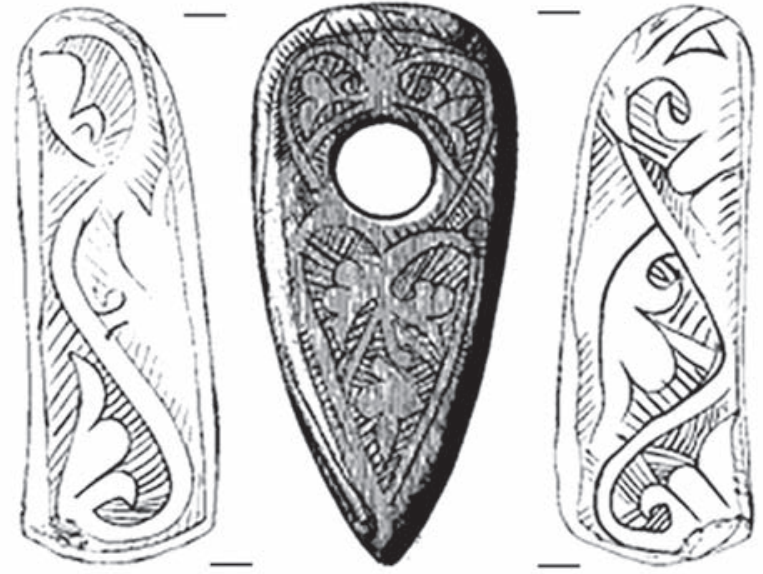

Ryc. 20. Kamień piorunowy z ornamentem romańskim z Västergötland, Szwecja (wg Montelius 1906, ryc. 100). Ryc. nieskalowana. Oprac. T. Kurasiński

Fig. 20. A thunderstone with a Romanesque ornament from Västergötland, Sweden (after Montelius 1906,

Fig. 100). Fig. unscaled. By T. Kurasiński

257). Z imieniem właściciela wiązany jest także napis (kaus) na jednej z siekier ze Szwedzkiego Muzeum Historycznego w Sztokholmie (ryc. 21:2) (Snædal et al. 1988, 247, ryc. 13). W tamtejszych zbiorach znajduje się też okaz z teonimem boga Thora, wyrytym przypuszczalnie w XIV w. (ryc. 21:3) (Snædal et al. 1988, 247, ryc. 12). Imiona bogów skandynawskich (inicjały) widnieją zapewne też na zaginionym okazie z Uppsali, opublikowanym przez É. Cartailhaca $(1878,34$, ryc. 18) (ryc. 21:4). Na egzemplarzu z Vejle (Jutlandia) odczytano natomiast formułę magicznomedyczną (ryc. 21:5) (Grünzweig 2004, 157, 159-160, ryc. 54; Quast 2011, 257-258, ryc. 9:1; zob. także MacLeod, Mees 2006, 121). Z kolei siekiera znaleziona w Erga (Norwegia) ma szeroko datowane runy (lata 100-700), które przypuszczalnie mogą oznaczać: dar [od] boga/bogów [dających] radość lub dar [od] boga/bogów [i/lub] gnomów (ryc. 21:6). Według I.A. Grønbeck siekiera wykazywała związek z czcią dla wyższych mocy bądź funkcjonowała jako amulet, zarówno w życiu doczesnym, jak i poza nim. Niestety, brak wiedzy na temat okoliczności odkrycia (tak jak w przypadku wcześniej wymienionych zabytków) uniemożliwia uściślenie interpretacji tego znaleziska (Grønbeck 2016).

$\mathrm{Z}$ magią leczniczą wiązane są także ryty widoczne na wyrobach z Nowogrodu (ryc. 16:1) (Musin et al. 2018, 30, ryc. 8:a-b, 9:a). Na niektórych kamiennych archaikach fińskich i karelskich zostały wyryte symbole i znaki, takie jak pentagramy i pięciokąty 

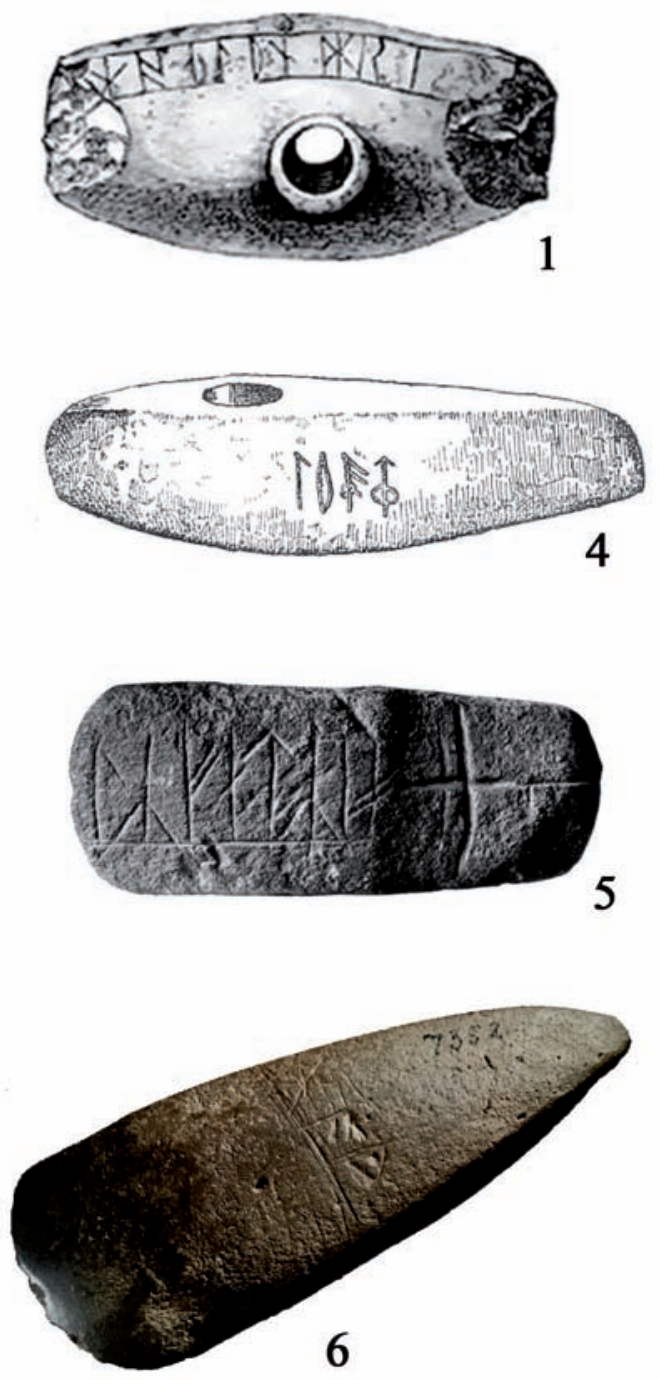
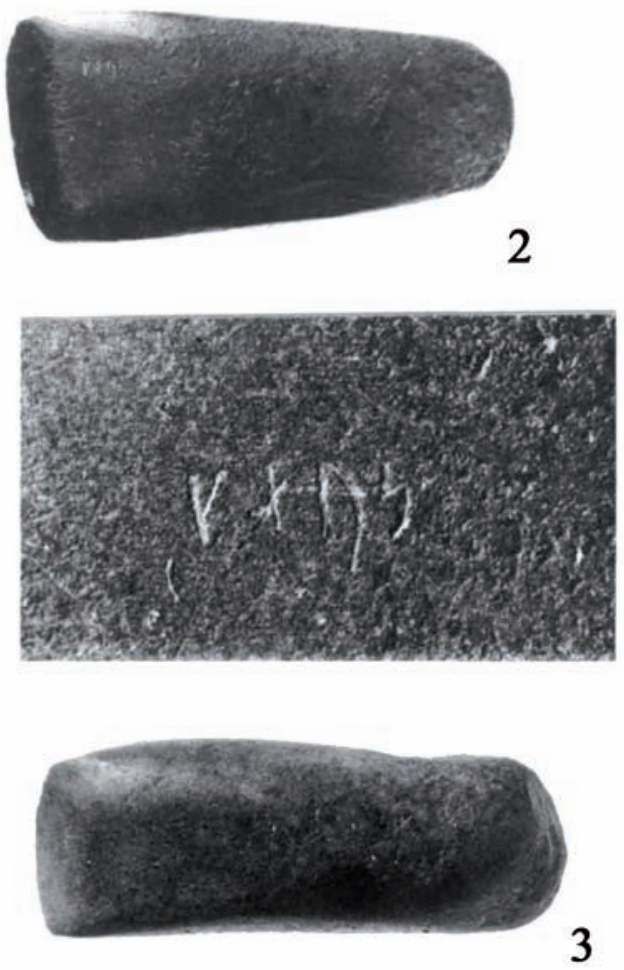

3

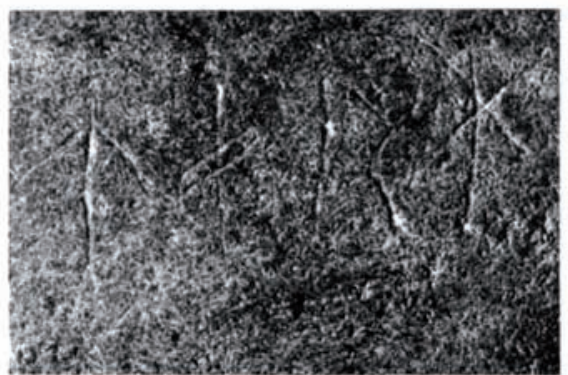

Ryc. 21. Kamienie piorunowe z runami: 1 - Upplandia, Szwecja (wg Montelius 1906, ryc. 99); 2-3 - miejsce odkrycia nieznane, zbiory Szwedzkiego Muzeum Historycznego w Sztokholmie (wg Snædal et al. 1988, ryc. 12-13); 4 - Uppsala, Szwecja (wg Cartailhac 1878, ryc. 18); 5 - Vejle, Dania (wg Quast 2011, ryc. 9:1);

6 - Erga, Norwegia (wg Grønbeck 2016, ryc. na s. 21). Ryc. nieskalowane. Oprac. T. Kurasiński

Fig. 21. Thunderstones with runes: 1 - Uppland, Sweden (after Montelius 1906, Fig. 99), 2-3 - place of discovery unknown, collection of the Swedish Historical Museum in Stockholm (after Snædal et al. 1988, Fig. 12-13), 4 - Uppsala, Sweden (after Cartailhac 1878, Fig. 18), 5 - Vejle, Denmark (after Quast 2011, Fig. 9:1), 6 - Erga, Norway (after Grønbeck 2016, Fig. on p. 21) . Fig. unscaled. By T. Kurasiński

(ryc. 14). W tym wypadku również miały one na celu zwiększenie magicznej mocy ochronnej przedmiotu (Muhonen 2006, 8; Kunnas-Pusa 2016, 17).

Zdaniem D. Quasta bezpośrednie wywodzenie $\mathrm{z}$ okresu rzymskiego kamiennych toporów $\mathrm{z}$ magicznymi napisami jest mało prawdopodobne. Tym niemniej zjawisko to jest przejawem uniwersalnych, przekazywanych od stuleci, wierzeń związanych $\mathrm{z}$ kamieniami piorunowymi, wspartych wiarą w moc pisma (Quast 2011, 258). Odnosić się to może także do innych, znacznie późniejszych znalezisk. Powołać się można na fragment topora odkryty w nawarstwieniach z połowy XIV w. Twerskiego Kremla, z naniesionym liternictwem alfabetu cyrylickiego (ryc. 16:13) (Rozhdestvenskaya 2001, 211, 214, ryc. 2:1; Lapshin 2009,137 , ryc. 61:1). Uważa się, iż takie sygnowanie przedmiotu o odległej metryce sprawia wrażenie konieczności wpisania go w kulturę chrześcijańską, przy czym już same litery mogą mieć znaczenie sakralne (Ivakin, Chernetsov 2002, 529). 
Przywołane wyżej egzemplarze, poprzez swą fizyczną przemianę, stawały się nośnikami magicznych napisów i symboli, przy czym sam nośnik, jak również naniesione na niego znaki wzajemnie potęgować powinny swoje specjalne moce. Przedmioty takie były tym samym dostosowywane do aktualnych potrzeb i wymagań kultowo-religijnych (Bagley 2015, 198).

Wprowadza to nas w zagadnienie umieszczania na pradziejowych wyrobach motywów chrześcijańskich. Niektóre ciosła i młoty neolityczne zaopatrywano w wizerunki krzyża. Na egzemplarzu z Lyubeneva (Bułgaria) wyryto krzyż grecki (ryc. 18:1) (Aladzhov, Balabanyan 1972, 130, ryc. 34). Analogiczny symbol widnieje też na srebrnej oprawie, do której włożono fragment neolitycznego narzędzia, którego okoliczności odkrycia nie są znane (Quast 2011, 255, ryc. 7:2; Musin et al. 2018, 18, ryc. 2:2). Pojawienie się krzyży na obydwu wyrobach datowane jest przez D. Quasta już na wczesny okres bizantyjski (Quast 2011, 255, ryc. 7:1-2), podczas gdy inni badacze wskazują na średniobizantyjski (Musin et al. 2018, 18). Symbolika zawarta na powyższych przedmiotach pozwala uznać je za amulety chrześcijańskie, przy czym nie jest jasne, czy chodziło o znaczenie ochronne czy raczej - wzorem wspomnianych amuletów antycznych - bardziej istotny był kontakt $\mathrm{z}$ bóstwem (Quast 2011, 255).

W powyższym kontekście na szczególne wyróżnienie zasługują dwa kamienne okazy. Jeden $z$ nich to także już wzmiankowany topór z Kijowa $\mathrm{z}$ wyrytymi postaciami Matki Bożej, z rękoma uniesionymi na wysokość ramion (na piersi medalion ze schematycznym popiersiem przedstawiającym Dzieciątko Jezus) i św. Szczepana w długiej szacie, trzymającego w prawej ręce kadzielnicę, w lewej - trudny do zidentyfikowania przedmiot. Na przedmiocie widoczne są także litery (ryc. 17). Grawerunku dokonano najprawdopodobniej w XII w., ze wskazaniem na pierwszą połowę stulecia (Ivakin, Chernetsov 2002, 522; Ivakin 2007, 42). Jego stylistyka i program ikonograficzny całkowicie odpowiadają bizantyjskiej tradycji artystycznej Opracowanie górnej części przedmiotu wskazuje używanie go jako zawieszki (Ivakin 2002; Ivakin, Chernetsov 2001; Ivakin, Chernetsov 2002; Ivakin, Putsko $2005,94-95$, ryc. 1). Drugi to neolityczna siekiera (przypuszczalnie z diorytu) przechowywana $\mathrm{w}$ Metropolitan Museum of Art w Nowym Jorku, na której z jednej strony wyobrażono św. Eliasza (Elijah) na rydwanie, a na drugiej scenę Ukrzyżowania (ryc. 22). Przedstawienia te powstały w X w. (Labatt 2018).
Wykorzystanie chrześcijańskiej symboliki na wyrobach o metryce sięgającej odległej przeszłości, wykazujących konotacje pogańskie, wiązane jest z synkretyzmem wierzeniowym, skutkującym m.in. pojawianiem się idei wytwarzania takich amuletów. Idąc tym tropem, znalezisko kijowskie można intepretować jako kolejny, bardziej wyrazisty i zaawansowany etap tego procesu. Według tej koncepcji nie doszło wszakże do „połączenia” dwóch wyznań czy religii. Należałoby raczej mówić o reliktach pogaństwa słowiańskiego w chrześcijańskim średniowieczu. Pozostałości pogańskiego światopoglądu przejawiały się w późniejszej świadomości religijnej jako związek z przodkami (Ivakin 2002, 11; Ivakin, Chernetsov 2002, 528; zob. także Malakhova 2009, 72). Ze względu na surowiec w interpretacji amuletu kijowskiego zwrócono też uwagę na powiązania św. Szczepana i Bogurodzicy oraz Chrystusa z symboliką kamienia oraz analogie między bóstwami gromowładnymi a Bogiem stwórcą świata (Chernetsov 2002; Ivakin, Chernetsov 2002, 529, 531). Dostrzega się w nim także przejaw staroruskiej „kultury wojskowej", posługującej się atrybutami o charakterze społecznym i religijnym (Musin 2005, 195-196).

Amuletem niewątpliwie był także drugi z wymienionych wyrobów. Wskazuje na to otwór wykonany w obuchu. Ponadto, towarzyszące inskrypcje naniesione na przedmiot $\mathrm{w}$ odwrotnym układzie ukazują bezpośrednią relację $\mathrm{z}$ właścicielem (dają się poprawnie odczytać tylko z pozycji osoby spoglądającej z góry). Mógł być zatem noszony na szyi, ewentualnie wokół talii (Labatt 2018, 163, 171).

Przedmiot ten lokowany jest w nieco innej perspektywie interpretacyjnej aniżeli egzemplarz z Kijowa. Jej podstawę stanowi założenie, że zagadkowe pochodzenie kamieni piorunowych i ich rozległa moc są przywłaszczane, wprzęgane i wzmacniane już jako obiekty chrześcijańskie $\mathrm{w}$ ramach nowego systemu wierzeniowego. Znajdujące się na nim przedstawienia are purely Christian and are thus less about assembling and conflating conflicting belief systems, and more about absorbing and redirecting the past histories of the object toward a Christian present (Labatt 2018, 165). Konkretny wybór scen biblijnych i sposób, w jaki odnoszą się one do siebie, wyrażają stopień, w jakim omawiany przedmiot wykreowano na chrześcijański emblemat. Ich treść koncentrująca się wokół idei wniebowstąpienia lub wzniesienia się ku niebiosom (wstąpienie Eliasza do nieba jako zapowiedź zmartwychwstania Chrystusa) wzmacniać mogła przekonanie o niebiańskim pochodzeniu przedmiotu (Labatt 2018, 166). 

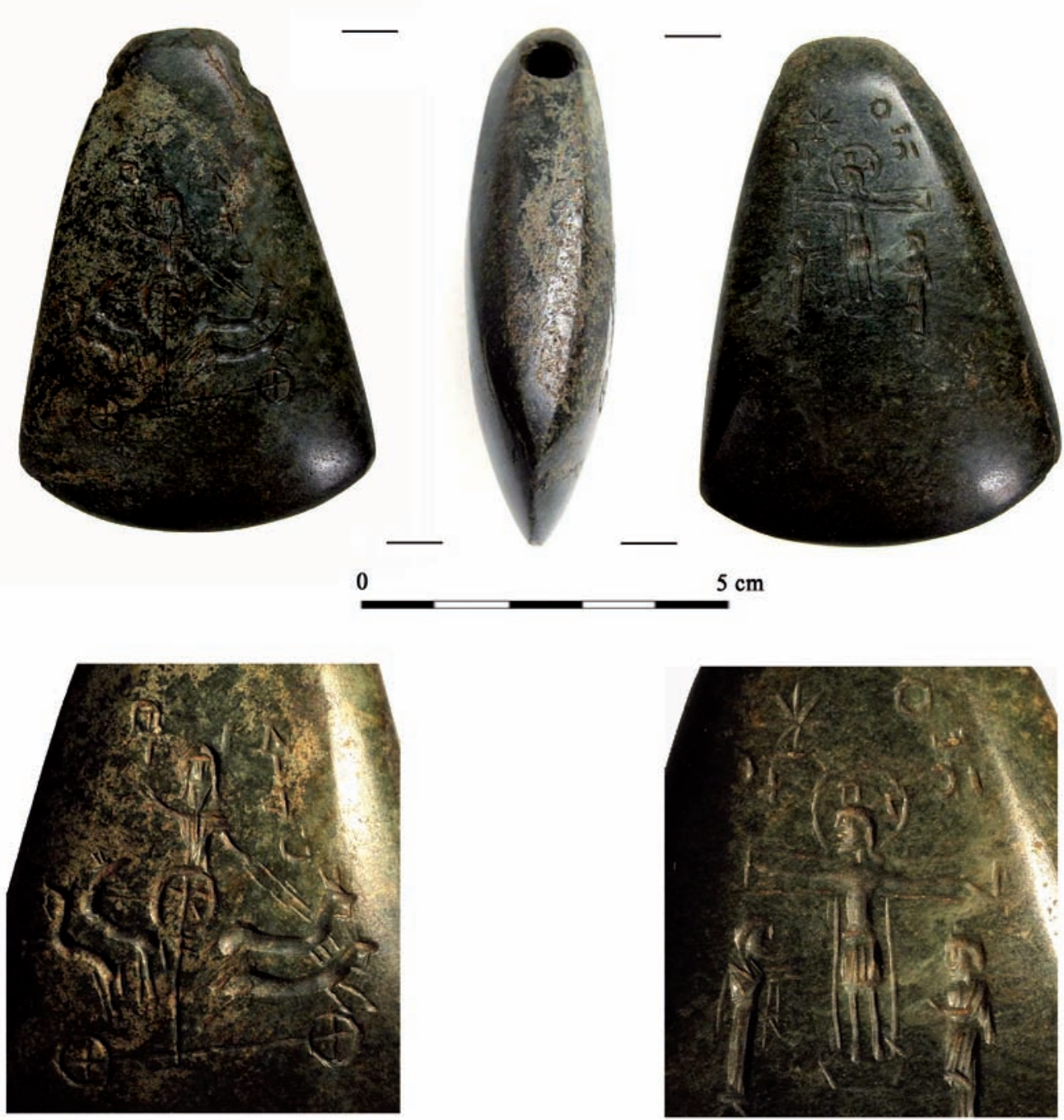

Ryc. 22. Amulet z Metropolitan Museum of Art w Nowym Jorku (wg Labatt 2018, ryc. 4 i na s. 162).

Oprac. T. Kurasiński

Fig. 22. An amulet from the Metropolitan Museum of Art in New York (after Labatt 2018, Fig. 4 and Fig. on p. 162). By T. Kurasiński

A.M. Labatt odwołuje się także do innych przekazów biblijnych, m.in. do przypowieści o cudownym wyciągnięciu topora z Jordanu przez Elizeusza, ucznia Eliasza, za pomocą kawałka drewna. W wykładni chrześcijańskiej tekst ten interpretowano jako zapowiedź ukrzyżowania Chrystusa i zbawienia ludzkości, a sam topór stał się symbolem upadłego człowieka, zmartwychwstałego z Chrystusem. W tym znaczeniu pogańska przeszłość wcielona $\mathrm{w}$ to narzędzie mogła przypominać o grzesznym stanie noszącego zawieszkę w takim kształcie ${ }^{35}$.

35 Jak jednak sama autorka zaznacza, słuszność takiego odczytania zależała od świadomości, czy posiadany obiekt to topór, czy kamień piorunowy (Labatt 2018, 171).
Spoczywający na piersiach amulet miał zatem skłaniać do modlitwy i uzmysławiać sens zmartwychwstania poprzez bezpośrednie skupienie uwagi na sceny wniebowstąpienia i ukrzyżowania (Labatt 2018, 170-172).

W konkluzji badaczka stwierdza, iż opisywany kamień gromowy przeszedł swoistą metamorfozę $\mathrm{z}$ obiektu uformowanego $\mathrm{w}$ niebiosach $\mathrm{w}$ ziemski przedmiot. Poprzez późniejsze dodanie postaci Chrystusa i Eliasza nastąpiła rekonfiguracja i przekierowanie przeszłości obiektu ku chrześcijańskiemu przeznaczeniu (zmartwychwstanie). W takim ujęciu Neolithic stone retains vestiges of the past while simultaneously changing into something utterly different - a Christianized palimpsest (Labatt 2018, 173). 
Pozostając przy inskrybowaniu omawianych przedmiotów w późniejszych okresach, warto wspomnieć o okazach z wyrytą datą roczną. Była już mowa o toporze norweskim, na którym znajdował się ciąg cyfr "1617" (ryc. 10:2). Powód ich naniesienia nie został wyjaśniony. Stwierdzono jedynie ogólnie, iż w ten sposób przedmiot zyskał na znaczeniu (Lødøen 1993). Z kolei na złamanym i oszlifowanym toporze odkrytym pod podłogą XIX-wiecznego domu w Kokkola (Finlandia) widnieje data „1830”. Może ona upamiętniać moment posadowienia domostwa (Hukantaival 2019, 358, 379). Mamy informację o jeszcze jednym analogicznym przypadku. Na egzemplarzu z północnych Niemiec (dokładna lokalizacja nie jest znana) widnieje data „1571”. Według dawnej koncepcji J. Evansa chodzi prawdopodobnie o rok, w którym doszło do odkrycia przedmiotu (Evans 1897, 58).

Ostatnim omówionym w tej części pracy jest topór z Södra Vi (Smalandia, Szwecja) z ciągiem liter MBS (dwie pierwsze złączone) wyrytych na płaszczyźnie bocznej (ryc. 10:9). Okaz ten pierwotnie używany jako środek ochronny przed pożarem został odziedziczony w XIX w. przez rodzinę szwedzkiego parlamentarzysty Nilsa Magnussona. Litery MBS wskazują na jego ojca, Magnusa Bengtssona, który naniósł je na przedmiot (Hammarstedt (1920, 17, ryc. 22).

\section{Rola kamieni piorunowych w leczeniu ludzi i zwierząt}

Pradziejowe wyroby z kamienia wszechstronnie wykorzystywane były w medycynie ludowej, która na ogół niewiele odbiegała od praktyk magicznych. W południowych Czechach przedmioty te nazywano nawet „kamieniami leczniczymi” (Fröhlich 1992, 239; Sklenáŕ 1999, 45). Istnieją doniesienia, iż na Łotwie w XIX i pierwszych dziesięcioleciach XX w. szeroki asortyment pradziejowych wyrobów, w tym kamiennych, znajdował się w rękach guślarek i znachorek (Vasks 2003, 30) ${ }^{36}$. Nie sposób w tym miejscu odnieść się do całości tego obficie udokumentowanego zagadnienia, ograniczymy się zatem tylko do wybranych przykładów.

36 Istnieją wystarczające podstawy, by w znachorach widzieć pomocników Boga i świętych władających piorunami. Stąd ich umiejętność posługiwania się kamieniami piorunowymi w leczeniu chorób i zwalczaniu zła (Libera 2003, 199-200).
Jak już wzmiankowano, szczególną wartość przypisywano proszkowi zeskrobywanemu z przedmiotu, który zalecano na różne dolegliwości. W świetle przekazów taka forma medykamentu znajdowała szerokie zastosowanie w tradycyjnym lecznictwie. Proszek taki $\mathrm{w}$ połączeniu $\mathrm{z}$ wodą, alkoholem lub octem podawano doustnie przy różnego rodzaju dolegliwościach, m.in. żółtaczce, gorączce, skurczach, bólach brzucha, chorobach wieku dziecięcego (np. Koudelka 1882, 160; Biegeleisen 1929, 343, 344; Skutil 1932, 44; Olbrich 1987,328; Ramminger2007, 12; Šimek 2010, 141-142; Wdowiak, Wysokiński 2013, 537-538). Posypywano nim także rany (Tolstoy 1995, 562; Muhonen 2006, 8).

Niekiedy wystarczyło, że kamień piorunowy znajdował przez jakiś czas w wodzie lub innym płynie. W Kornwalii w końcu XIX w. wodę, w której gotowano kamienne narzędzie, podawano jako środek na reumatyzm (Evans 1897, 56-57; Penney 1976, 72; Merrifield 1987, 13). W rejonie jeziora Kenozero (północna Rosja) w przypadku kłucia w boku przedmiot taki polewano wodą, którą chory otrzymywał do picia (Shevelev 2005, 2).

$\mathrm{Na}$ ogół kamienie piorunowe (na zimno lub po rozgrzaniu) przykładano i dotykano niedomagające partie ciała, wspierając się często przy tym wypowiadaniem zaklęć. W ten sposób starano się pozbyć m.in. stanów zapalnych, powikłań ruchowych, torbieli, obrzęków, woli i wielu chorób skórnych, a ponadto uśmierzyć wszelkie bóle (np. Lovisato 1878, 504; Koudelka 1882, 160; Palliardi 1889; Skutil 1932, 4344; Kaufmann 1936, 34; Horoszkiewicz 1950, 160; Olbrich 1987, 328; Plessingerová, Vařeka 1999, 211; Sklenáŕ 1999, 46-49; Hála 2016a, 49-50) ${ }^{37}$. Dla uniknięcia przypadłości reumatycznych w niektórych rejonach Hiszpanii, np. w prowincji Salamanca, zalecano pocieranie nimi stawów (Pedrosa 2009, 268; Rúa Aller, García Armesto 2010, 66).

W Szkocji wierzono, że perforowane siekiery jadeitowe z neolitu zawieszone na pasie leczyły dolegliwości nerek (Penney 1976, 72). Istnieje informacja, iż w latach 60. XIX w. z tego właśnie powodu jedna

37 W Transylwanii (Drăguș) pomagały na paraliż kończyn, wywołany przez istoty zwane iele (zob. przyp. 19). Chorego należało wykąpać w przefiltrowanej przez, pozostawione przez nie, kamienne topory. Dokonać tego powinny stare kobiety przed świtem (Ofrim 2019, 99). W celach leczniczych wykorzystywano również odłamki drzewa, w które uderzył - jak mniemano - klin piorunowy, które pomagać miały na wściekliznę, a szczególnie uśmierzać ból zębów (Skutil 1932, 40; Hložek et al. 2015, 274; Hála 2016a, 52-53). 


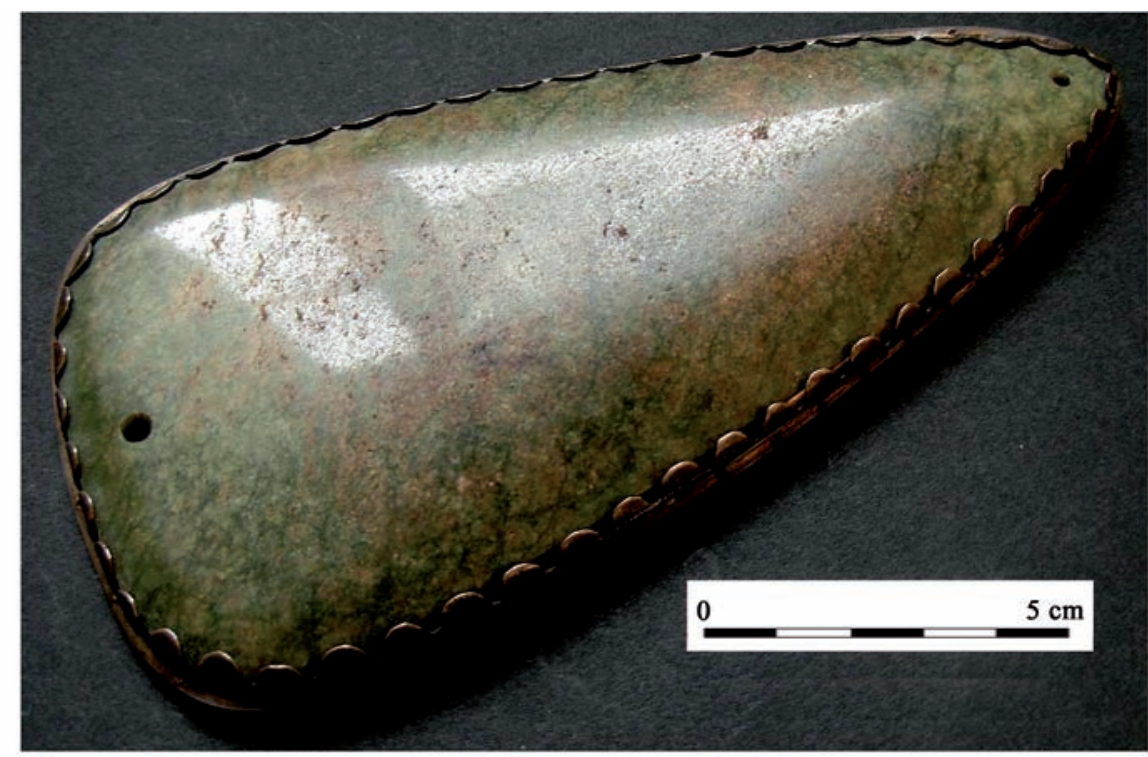

Ryc. 23. Siekiera jadeitowa ze Szkocji lecząca nerki (wg Sheridan et al. 2011, ryc. 8). Oprac. T. Kurasiński

Fig. 23. An axehead of jadeitite from Scotland that heals kidneys (after Sheridan et al. 2011, Fig. 8). By T. Kurasiński

z nich (typu Altenstadt) stała się własnością szkockiego oficera. Okaz ten zaopatrzono na końcach w otwory i wstawiono w srebrną oprawę, tak aby można było go nosić jak sporran - futrzaną lub skórzaną torbę, będącą elementem uroczystego stroju szkockiego (ryc. 23) (Sheridan et al. 2011, 8-9, ryc. 8). Znane są przypadki stosowania siekier $\mathrm{z}$ jadeitu $\mathrm{w}$ tego rodzaju niedomaganiach także na wsiach francuskich, np. w departamencie Żyrondy (Saintyves 1936, 173-174). W schorzeniach nerkowych pomóc miał także okaz przywieziony z Turcji około $1670 \mathrm{r}$. przez ambasadora Francji i podarowany księciu François de Lorraine, biskupowi Verdun (Cartailhac 1878, 31-32; 1889, 4; Evans 1897, 59; Saintyves 1936, 98; Sklenáŕ 1999, 33).

Należy tu wspomnieć, że w nowożytnej farmaceutyce, w której Lapis Ceraunius (kamienne artefakty pradziejowe) obok Lapis Lyncis (kamienie rysia, czyli belemnity) najczęstsze zastosowanie znajdowały w kamicy nerkowej i żółciowej ${ }^{38}$. Niszczący efekt medykamentów preparowanych z klinów piorunowych wyobrażano sobie jako „miażdżenie” i „łama-

38 Pozyskany proszek pojawia się w oficjalnych farmakopeach, np. w pruskim Dispensatorium Borusso-Brandenburgicum (1698), w którym ustalono wysoką cenę za jego sprzedaż (Sachße 2008, 234). Duże znaczenie medyczne przypisywane pradziejowym wyrobom mogło być powodem, dla którego tego rodzaju przedmioty znajdowały się w zbiorach rodziny farmaceutów Lincków z Lipska (Meinecke 2014, 49; zob. także Wasz 2014). nie" przyprawiających o cierpienie złogów (Sachße 2008, 238).

Ceraunii używano także m.in. przeciw gorączce, przy gojeniu ran i przepuklinach (tu jako element uciskowy opasek przeciwprzepuklinowych) (Sachße 2008, 239-240). W Hiszpanii (zwłaszcza w Galicji, Asturii i León) pomagały też przy ukąszeniu węża i innych jadowitych zwierząt (García Castro 1988, 439; Quintía Pereira 2009, 5; Rúa Aller, García Armesto 2010, 66; Aguirre Sorondo 2013, 141).

Medyczną skuteczność przypisywano polerowanym i perforowanym siekierom, mocowanym do różańców, jak to miało miejsce w Bretanii (Saintyves 1936, 117).

Warto dopowiedzieć, iż w połowie XVIII w. znaleziska te zaczynają znikać z wykazów zalecanych leków. Chociaż nadal były obecne w wielu aptekach, z wolna odchodziły do przeszłości. Wynikało to przede wszystkim z postępu wiedzy medycznej z jednej strony, z drugiej zaś archeologicznej, aczkolwiek poprawna interpretacja kamieni piorunowych nie przyczyniła się do automatycznego zaprzestania stosowania ich w charakterze środka leczniczego (Sachße 2006, 5; Sachße 2008, 241). Wiara w skuteczność uzdrowicielską tych przedmiotów daleka była od całkowitego zapomnienia ${ }^{39}$, nie tylko zresztą - jak

39 Długo też pokładano ufność w ochronną moc kamieni piorunowych. Jeszcze na początku wojny francuskopruskiej w 1870 r. niemieccy żołnierze nagminnie wykupywali je w aptekach, aby móc uchronić się przed pociskami 


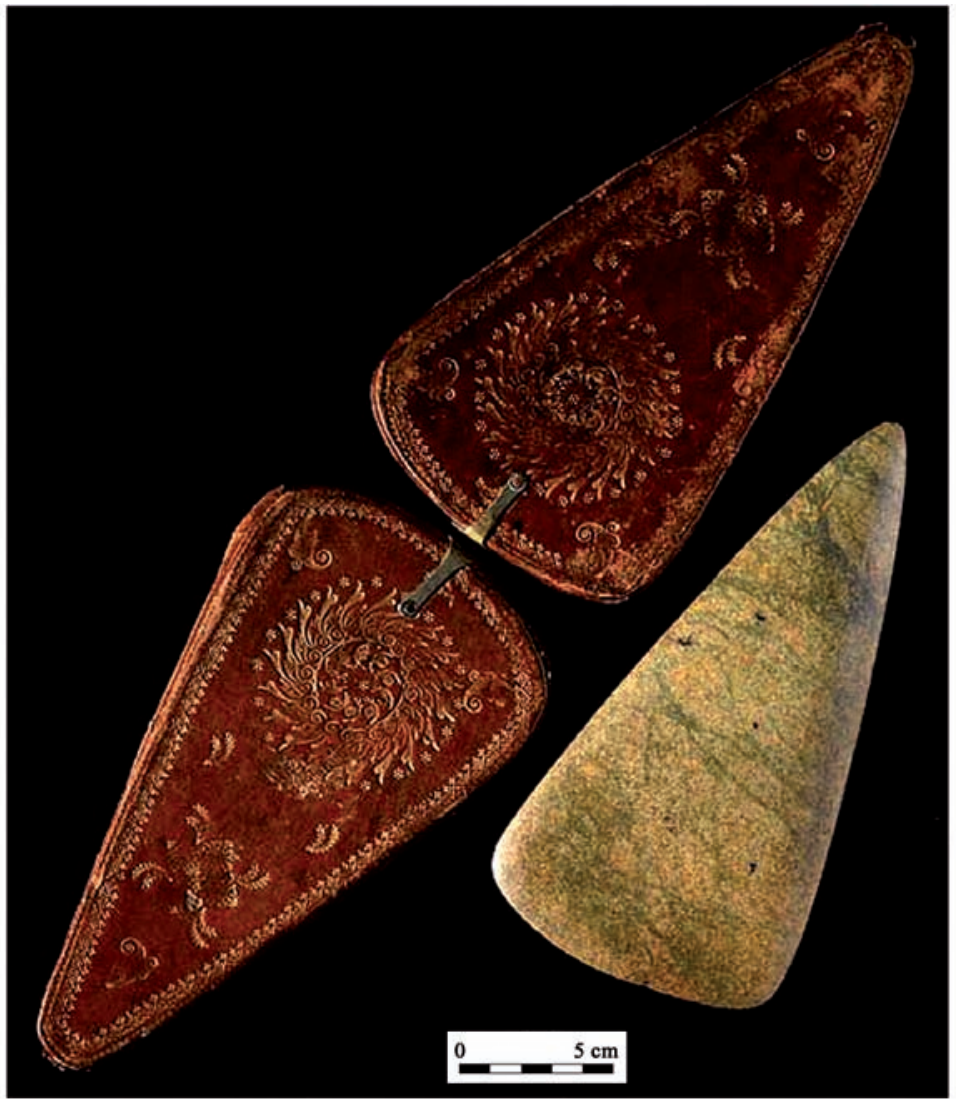

Ryc. 24. Siekiera jadeitowa ze Szkocji z futerałem (wg Sheridan et al. 2011, ryc. 9). Oprac. T. Kurasiński

Fig. 24. An axehead of jadeitite from Scotland and its case (after Sheridan et al. 2011, Fig. 9). By T. Kurasiński

mogliśmy się przekonać - w środowisku wiejskim. O przekonaniu co do ich leczniczych lub ochronnych właściwości wśród elit społecznych świadczyć może także wyszukany sposób przechowywania takich przedmiotów. W Szkocji około 1700 r. wykonano pieczołowicie zdobiony skórzany pokrowiec, w którym przechowywano jadeitową siekierę typu Altenstadt (ryc. 24) (Sheridan et al. 2011, 9-10, ryc. 9).

Po kamienne archaika sięgano w leczeniu zwierząt domowych, zwłaszcza bydła, w czym również wiodącą rolę odgrywała magia.

W Niemczech, Czechach, na Śląsku i na Węgrzech kamienie piorunowe służyły do pocierania chorych wymion krów i kóz (Andree 1889, 32; Kaufmann 1936, 33; Olbrich 1987, 327; Sklenáŕ 1999, 51; Hála 2016a, 50-51; Hála 2016b, 90). Analogicznie postępowano w niektórych regionach Francji (Moselle) i Hiszpanii (Asturia, León), gdzie zazwyczaj moczono je uprzednio w mleku (Saintyves 1936; Blas de, Maya 1974, 213; Blas de, Villa Valdés 2007, 287; Pedrosa

wroga (Kaufmann 1936, 32; Reitinger 1976; 534; Olbrich 1987, 327; por. Saintyves 1936, 121).
2009, 261, 263, 265; Rúa Aller, García Armesto 2010, 65; Aguirre Sorondo 2013, 141). Tam też kuracja i zapobieganie rozmaitym niedomaganiom polegały na wieszaniu kamieni piorunowych na chorych zwierzętach oraz w obrębie zagród (Rúa Aller, García Armesto 2010, 66; Aguirre Sorondo 2013, 141), a we Francji (Kraj Loary) przed umieszczeniem na szyi nacierano je thuszczem (Saintyves 1936, 126). W Oldenburgu i wsiach bawarskich choremu bydłu kamienie piorunowe wkładano do żłoba, a na Pomorzu i w Szwecji pozyskany z nich proszek (Cartailhac 1878, 19, 22; Olbrich 1987, 327). Z kolei w Irlandii i w północnej Anglii ze względu na ich uzdrawiającą moc umieszczano je w korytach, z których pojono bydło (Evans 1897, 57; Merrifield 1987, 13). W wyżynnych rejonach Francji kamienie piorunowe gotowane były w wodzie przeznaczonej dla chorych owiec (Cartailhac 1878, 20). Natomiast w Holandii jeszcze niedawno używano ich w łagodzeniu bólu zębów u koni (Verhart 2016, 8).

Uważa się, iż w przeciwieństwie do prób uzdrowienia ludzi, praktyki dotyczące zwierząt były utrzymywane w tajemnicy, pilnie też strzeżono treści zaklęć. Leczeniu bydła towarzyszyła aura nieufności 
i ostrożności. Uzdrowiciel często był kojarzony ze złymi mocami, którym zawdzięczał swoje umiejętności (Sklenář 1999, 50; Hložek et al. 2015, 274; zob. także Kaufmann 1936, 33).

Sproszkowana forma medykamentu znajdująca szerokie zastosowanie w ludowej medycynie i weterynarii musiała pozostawiać ślady w postaci zadrapań, zarysowań czy ubytków, powstałe w wyniku jego pozyskania. Możemy powołać się na doniesienia etnograficzne. Dobrym przykładem jest topór znaleziony przez chłopa w rejonie Taurogów na Litwie, o którym twierdzono, że spadł na ziemię podczas burzy. Zeskrobany z niego proszek służył do leczenia ran, a sadzac po śladach w powyższym celu sięgano po niego niejednokrotnie (Pokrovskiy 1899, 39). Jeszcze w 1880 r. do sproszkowania i zaaplikowania dziecku użyta została kamienna siekiera z Boda (Smalandia, Szwecja), o czym doniósł N.E. Hammarstedt (1920, 17, ryc. 21) (ryc. 10:10). Z kolei w dawnym Leipziger Völksmuseums przechowywany był topór pozyskany od chłopki spod Lipska z calkiem świeżymi rowkami i bruzdami, pozostawionymi po pobraniu proszku (Seyfahrt 1913, 262).

Podobnie w zebranych materiałach wiele egzemplarzy wykazuje znaczne uszkodzenia. Nie wszystkie można wytłumaczyć ich pradziejowym pochodzeniem. Niektóre mogły powstać w następstwie nowego zastosowania artefaktów kamiennych już nawet w średniowieczu (Hložek et al. 2015, 274).

Rozpowszechnione przekazy o obskrobywaniu kamiennych wyrobów pradziejowych w celu pozyskania leczniczego proszku wydają się logicznym wyjaśnieniem wtórnego ścięcia ostrzy toporów odkrytych w Großgoltern, sprawiając, że ich pierwotna funkcja ostatecznie zanikła (ryc. 4:6) (Cosack 2004, 63; Sachße 2008, 237). Krawędzi tnącej celowo pozbawiony został też wspomniany topór z Mellenau (ryc. 4:2). W omawianym kontekście zwraca także uwagę intencjonalne starcie obu powierzchni siekieromłota pochodzącego z zamku Křivoklát w Czechach (ryc. 1:3) (Durdík 1997, 107) oraz późniejsze naruszenie pierwotnej formy okazów znalezionych w obrębie innej czeskiej twierdzy - Kozí Hrádek (ryc. 1:5-7) (Hložek, Menšík 2009, 67) ${ }^{40}$. Zadrapania zauważalne są także na siekierze z Železnej Rudy (ryc. 2:5). Do ich pojawienia się prawdopodobnie doszło dopiero wówczas, gdy przedmiot używany był już

$40 \quad$ Jeden $\mathrm{z}$ nich ma ponadto wtórne ślady wiercenia. Nie można wykluczyć, iż jest to nieudany wyrób (Hložek, Menšík 2009, 71-72). w charakterze klina piorunowego (Menšík 2018, 30). Wykorzystywanie sproszkowanego kamienia piorunowego może potwierdzać kilka artefaktów neolitycznych znalezionych w średniowiecznym Lund, które cechują się trudnymi do wyttumaczenia uszkodzeniami - odłamanymi krawędziami tnącymi lub wydrążonymi dołkami (Carelli 1996, 160, ryc. 4; Carelli 1997, 406, ryc. 6). Oba końce okazu z Upplandii zapewne również zostały uszkodzone w celu uzyskania skutecznego leku (ryc. 21:1) (Blinkenberg 1911, 91; Holtfort 2015, 83). Mogą to także sugerować ślady skrobania powierzchni niektórych narzędzi (cioseł) z Nowogrodu (ryc. 16:7) (Tyanina 2018, 68, ryc. 6:f), choć interpretuje się je także jako efekt ostrzenia metalowych narzędzi (Musin et al. 2018, 31). Dostrzeżono też wtórną ingerencję w strukturę okazów pochodzących z Estonii. Niekiedy pocierano tylko jedną stronę, tak że ostrze stawało się asymetryczne, jak w przypadku siekiery znalezionej w Kõnnu (Johanson 2009,145$)^{41}$. Z czasem, w wyniku dziesiątków lat pobierania leczniczych cząstek prowadziło do niemal zupełnej destrukcji przedmiotu zmniejszonego do małego okruchu, jak w przypadku kamiennego młota $\mathrm{z}$ gminy Punkalaidun w południowej Finlandii (Muhonen 2006, 8-9; Hukantaival 2019, 347). W 1893 r. aptekarz F. Prochno z Altmarku doniósł, iż niektóre egzemplarze będące $\mathrm{w}$ jego posiadaniu są tak dalece zeskrobane, iż ich pierwotna forma jest niemal nierozpoznawalna (Ramminger 2007, 12).

\section{Kamienie piorunowe w grobach}

Należy również odnieść się do znalezisk grobowych, których zbiór, jeśli chodzi o znaleziska kamienne, zdecydowanie ustępuje liczebnie zabytkom deponowanym gdzie indziej ${ }^{42}$. Niedostatek omawianych archaików w wyposażeniu pośmiertnym uzasadnia się ich niepraktycznością (nieporęcznością), czyli brakiem możliwości zawieszenia, ewentualnie ukrycia w sakiewkach, zawieszanych przy pasie. Zbyt duża masa takich przedmiotów powodowała, iż nie upowszechniły się one jako akcesorium osobiste,

41 Tak ukierunkowana analiza materiału z zachodniej Norwegii nie dała całkowitego potwierdzenia, czy do zaobserwowanych uszkodzeń doszło w wyniku zaleceń medycyny ludowej (Søyland 2017, 61, 81).

42 Listę kamiennych siekier i toporów można uzupełnić o kilka innych cmentarzysk, przede wszystkim merowińskich (zob. Mildenberger 1969, 7; tu literatura). 
a przeznaczano im miejsce głównie w domostwie (Ungerman 2009, 236). Wiadomo jednak, że wieszano je sobie na szyi, o czym najlepiej świadczą okazy z Kijowa i z Metropolitan Museum w Nowym Jorku. Są one jednak niewielkie ${ }^{43} \mathrm{i}$ zostały przystosowane do noszenia w formie zawieszki.

$\mathrm{O}$ ile nam jednak wiadomo, żaden ze znanych nam okazów pochodzących z grobu nie jest perforowany ani w jakikolwiek inny sposób przysposobiony do noszenia na ciele. Należy zatem raczej wykluczyć, iż znajdowały się one na szyi lub klatce piersiowej zmarłego. Warto natomiast podkreślić zróżnicowanie wielkościowe okazów o znanych parametrach (zakres od $6 \mathrm{~cm}$ do ponad $14 \mathrm{~cm}$ ), przy czym długość kilku z nich przekracza $10 \mathrm{~cm}$. Może to wskazywać na odmienne funkcje pełnione $\mathrm{w}$ grobie, trudne jednak do ustalenia. W literaturze przedmiotu na ogół akcentuje się magiczne i obrzędowe znaczenie. Okaz z wiatyckiego cmentarzyska według N.G. Nedoshiviny złożony został w magicznym celu (Nedoshivina 1976, 50). Według P.-L. Lehtosalo-Hilander narzędzia kamienne znalezione w Luistari należy uznać za amulety (ryc. 13:10-11) (Lehtosalo-Hilander 2000, 95, 107). Natomiast odkryty w Meerveldhoven fragment siekiery zinterpretowano ogólnie jako dar grobowy (Eijk van 2007, 213). Jak wspomniano, niewielką siekierę z Kvåle (6,2 x 4,9 x 1,7 cm) znaleziono wśród innych przedmiotów, najprawdopodobniej o specjalnym znaczeniu (przypuszczalnie wszystkie umieszczono w niewielkim pojemniku). Na tej podstawie uznano, że w grobie pochowano kobietę zajmującą się czarami (Søyland 2017, 22).

Szerzej w kwestii występowania kamieni piorunowych $\mathrm{w}$ grobach wypowiedzieli się E.S. Thäte i O.H. Hemdorff, w odniesieniu do siekiery (wymiary 11,6 x 3,6 x 3,7 cm - według Søyland 2017, 294) znalezionej w grobie z Avaldsnes (ryc. 10:14). Mamy tu jednak do czynienia $z$ dość wyjątkową sytuacją, gdyż zmarłego pochowano w starszym założeniu grobowym, splądrowanym następnie w XIX w. Pod uwage wzięto trzy możliwości: 1: siekierę celowo umieszczono w grobie jako część wyposażenia grobowego, 2: siekierę celowo umieszczono $\mathrm{w}$ grobie $\mathrm{w}$ ramach

43 Odpowiednio 5,1 x 3,4 x 2,2 cm (Ivakin 2002, 9) i $6,6 \times 4,7 \times 1,8 \mathrm{~cm}$ (Labatt 2018, 160). Koresponduje to z podziałem zaproponowanym dla kamiennych wyrobów z antyku, w którym wszystkie egzemplarze niewielkich rozmiarów to amulety osobiste, większe zaś - o długości 9-13 cm i 4-6 cm szerokości - służyły do magicznej ochrony zabudowań (Faraone 2014, 252). rytuału pogrzebowego (ochrona przed rabunkiem), 3: siekierę zostawili rabusie po splądrowaniu grobu, zabezpieczając się przed zemstą z zaświatów za swój niegodny czyn. Z jednej strony starano się więc uwzględnić wierzenia związane $\mathrm{z}$ apotropaicznym charakterem kamieni piorunowych, które również mogły odgrywać rolę w obrzędach pogrzebowych. $\mathrm{Z}$ drugiej zaś przesądy wiążące się z procederem rabowania pochówków (Thäte, Hemdorff 2009, 49-51).

Archaikom, głównie neolitycznym wyrobom, z cmentarzysk fińskich przypisuje się znaczenie religijne, symboliczne, upamiętniające i ekonomiczne. Według A. Wessman: When these objects finally were put into a grave, their role was possibly to display the deceased individuals' status or personhood within the community. By reburying old artefacts inside younger burials, people were able to express continuity even if these old objects did not come from their own past. It could have been a way to manipulate time by creating a longer history and another kind of origin myth (Wessman 2009, 84).

W niektórych przypadkach należy również liczyć się z bardziej prozaicznym przeznaczeniem kamiennych archaików pozyskanych z grobów. Ślady zaobserwowane na powierzchni siekiery ze Strand sugerują wtórne wykorzystanie jej jako osełki (Søyland 2017, 54, 248). Natomiast fragment topora $\mathrm{z}$ cmentarzyska w Piila mógł przypadkowo dostać się do grobu wraz z materiałem kamiennym wypełniającym i obudowującym grób, choć nie wyklucza się również jego związku z magią i kultem zmarłych (Johanson 2009, 151-152).

\section{Inne aspekty związane z kamieniami piorunowymi}

$\mathrm{Na}$ zmianę pierwotnej formy omawianych wyrobów wpływ mogły mieć także inne przyczyny. Ze względu na swe właściwości kamienie piorunowe były bardzo cenione i często dziedziczone przez kilka pokoleń ${ }^{44}$. Z tego też względu dochodziło do ich rozbijania i kawałkowania na mniejsze cząstki, jak w przypadku odnotowanym w XIX w. we wsi Vysočiny (Czechy). Tamtejszy gospodarz, wydając dwie córki za mąż tego samego dnia, przepołowił klin

44 Mając to na względzie, w Hiszpanii pozbycie się kamienia piorunowego", bez liczenia się z pozostałymi członkami rodziny, spotykało się ze złym przyjęciem (Pedrosa 2009, 262). 
piorunowy i dał każdej z nich na szczęście (Fröhlich 1992, 239). Czasami na skutek takiej relokacji pasujące do siebie części tych przedmiotów do muzeów trafiały z dwóch różnych wiosek (Reitinger 1976, 535). W Niemczech panna młoda otrzymywała klin piorunowy lub jego połowę. Podobny zwyczaj miał miejsce przy przeprowadzce do nowego domu (Olbrich 1987, 328; Ramminger 2007, 12). Znalezione w 1863 r. w Vihtra-Ülejõe (południowo-zachodnia Estonia) pod świerkiem trafionym przez piorun ciosło kamienne zostało złamane, tak aby z jego cudownych mocy mogło skorzystać więcej ludzi (Johanson 2009, 157, ryc. 6). Przedmioty te były dzielone, a następnie rozdzielane, dzięki czemu symbolicznie podtrzymywano wzajemne relacje i więzi (Houlbrook 2019, 196).

Szerokiemu zastosowaniu kamieni piorunowych dawano wyraz także w inny sposób. Ze źródeł historycznych i etnograficznych wynika, iż stawały się one przedmiotem handlu ${ }^{45}$, przywożonym niekiedy z miejsc pielgrzymkowych, np. Mariazell w Austrii (Červinka 1897b, 93; Skutil 1932, 49; Fröhlich 1992, 240; Sklenáŕ 1999, 57). Spieniężano je także starożytnikom i antykwariuszom, co jednak wcale nie musiało równać się deprecjacji magicznych właściwości tych artefaktów, gdyż sprzedaż mogła być wymuszona sytuacją kryzysową bądź ubóstwem (zob. Dowd 2018, 466). Ostatecznie to: The nature of the person responsible for the find and his or her own belief system must have been a crucial factor in deciding the fate of an archaeological artefact. For some individuals, all artefacts may have possessed supernatural properties, while for others artefacts may have been viewed simply as saleable commodities (Dowd 2018, 466-467). Tak czy inaczej zyskiwały one, przynajmniej w niektórych przypadkach, znaczącą wartość ekonomiczną (Klecanda 1901; Skutil 1932, 38; Reitinger 1976, 535; Plessingerová, Vařeka 1999, 210; Malakhova 2009, 71; Kunnas-Pusa 2016, 13), co mogło skłaniać do podrabiania autentycznych okazów.

Za falsyfikat należy uznać jeden z dwóch okazów zamurowanych w ścianie budynku gospodarczego w Mylau (dziś dzielnica miasta Reichenbau w Saksonii). Przypomina płaską motykę, ale jest naturalnym okruchen skalnym ze śladami obróbki na bokach (Geupel 1987, 4, tabl. 1:b). Ze względu na nietypową formę, imitacją ewentualnie nieukończo-

45 Zdarzało się, jak np. na Śląsku, że pożyczano je sobie odpłatnie (Reitinger 1976, 535; Olbrich 1987, 328). O użyczaniu ich sąsiadom i znajomym mamy także informacje z Turyngii (Kaufmnn 1936, 34). nym przedmiotem, jest okaz odkryty w Sebranicy (Czechy), w destrukcji związanej z domem zbudowanym w końcu XVII w. (Merta 2013). O fałszerstwie przypuszczalnie można mówić w przypadku dwóch okazów z Finlandii. Jeden to kamień przypominający topór odkryty we wsi Hietala pod podłogą suszarni i przekazany do muzeum w 1898 r. Drugi, będący imitacją neolitycznego narzędzia (ewentualnie osełką), pozyskano podczas badań archeologicznych w 2002 r. na stanowisku Torsby Sigfrids. Zlokalizowano go w dość niejednoznacznym związku z fundamentem pieca wewnątrz pozostałości budynku z XVII-XVIII w. (Hukantaival 2016, 182, 324, 333).

$\mathrm{Z}$ drugiej strony starano się wypracować metody pozwalające upewnić się w kwestii magicznej skuteczności kamieni piorunowych i dawać gwarancję ich autentyczności. Przed burzą miały one się poruszać i „pocić się", a przede wszystkim owinięte wokół nich sznur lub nić nie ulegały działaniu ognia. Takim praktykom i obserwacjom poddawano je niemal w całej Europie (zob. np. Lovisato 1878, 504; Bartel 1893, 561; Evans 1897, 57, 58; Skutil 1932, 40; Saintyves 1936, 165; Olbrich 1987, 326; García Castro 1988, 439; Sklenář 1999, 45; Muhonen 2006, 11; Pedrosa 2009, 261, 262, 266, 267, 268; Hála 2016a, 49). Niebiańskie pochodzenie kamieni piorunowych, a tym samym ich wiarygodność, potwierdzał także ich szczególny zapach (Sklenář 1999, 41).

W tej części rozważań na omówienie zasługuje także znalezisko z Räppe (Smalandia). Odkryty w neolitycznym grobie skrzynkowym przepołowiony kamienny topór został celowo złożony pod średniowiecznym monetami (ryc. 10:3). W ten sposób starano się zabezpieczyć skarb przed niepożądanym ujawnieniem, a być może nawet liczono na jego pomnożenie. Już sam wybór na kryjówkę pogańskiego cmentarza, który jako miejsce nieczyste, zapewniać miał magiczną nietykalność ukrytych tam dóbr. Dodatkowym zaś środkiem ochronnym ustanowiono interesujący nas przedmiot (Kjellmark, Thordeman 1939, 80-81, 89). Mógł on być znaleziony przypadkowo podczas deponowania monet, a następnie - jeśli był cały - został przełamany na dwie części. Jedna pozostała na miejscu, drugą przypuszczalnie zabrano, by w ten symboliczny sposób skarb powiązać ze swym właścicielem (Kjellmark, Thordeman 1939, 70).

Warto także wskazać na wtórne, nieużytkowe wykorzystania kamiennych utensyliów neolitycznych w późniejszej broni ceremonialnej. Z Reutlingen (Niemcy) pochodzi miecz z 1. połowy XVI w., którego głowica zastąpiona została przez kamienny 
topór (Ströbele 1992). Ze średniowiecza i czasów nowożytnych zachowały się także topory z „żeleźcami” w postaci podobnych narzędzi, na czele z tzw. młotem św. Marcina przechowywanym w Museum Catharijneconventin w Utrechcie (Cederström 1920; Quast 2011, 257, ryc. 8:1-2; Vilsteren van 2011; Knight et al. 2019, 1-2, ryc. 1.1).

„Archeologicznym” potwierdzeniem ceremonialnego użycia kamiennych okazów wydaje się być siekieromłot odkryty w zniszczonym budynku z XIII w. w miejscowości Hlepen (Rosja). Miał on żelazny pręt w otworze, zastosowany do skuteczniejszego umocowania toporzyska (ryc. 16:12) (Gasanov 2018, ryc. na stronie 119; Pyvovarov, Il'kiv 2014, 7). Podobnym rozwiązaniem konstrukcyjnym cechował się kamienny obustronny topór wydobyty z rzeki Waal w pobliżu Nijmegen (Holandia). Inny okaz z tego obszaru zaopatrzony został w żelazną tulejkę, tak samo służącą zaklinowaniu toporzyska (Modderman 1964, 69-71, ryc. 1, 3; Eijk van 2008, 172, ryc. 2). Jakkolwiek kontekst odkrycia nie jest znany ${ }^{46}$, zdaniem niektórych badaczy przeznaczenie kultowe obydwu przedmiotów, zarówno w momencie powstania (koniec epoki brązu), jak i później, gdy stosowano już żelazo, nie powinno budzić wątpliwości (Modderman 1964, 72-73; Eijk van 2008, 172). Warto dopowiedzieć, że w drewniane toporzysko został zaopatrzony wymieniony wcześniej topór odkryty na grodzisku gdańskim (ryc. 18:12).

\section{Utrata wiary w kamienie piorunowe}

Z czasem przekonania o magiczno-apotropaicznej i uzdrowicielskiej mocy kamieni piorunowych zaczęły należeć do przeszłości. Proces ten nie wszędzie przebiegał tak samo i miał zapewne lokalne uwarunkowania. Wydaje się jednak, iż koniec XIX w. oznaczał szybko postępującą erozję wiary w omawiane przedmioty, choć tu i ówdzie należy liczyć się z jej dalszym reliktowym trwaniem, zwłaszcza w tradycyjnym środowisku wiejskim (zob. np. Blinkenberg 1911, 1, 4; Muhonen 2006, 12; Johanson 2009, 163; Hukantaival 2016, 182; Hukantaival 2019, 358-359; Kunnas-Pusa 2016, 13).

Wraz z utratą ufności w nadprzyrodzone właściwości kamieni piorunowych można spodziewać się

46 Związek z pobliskimi nikłymi pozostałościami domniemanego ośrodka świątynnego z okresu rzymskiego jest niepewny. trzech kierunków ich dalszego traktowania. Mogły one być postrzegane jako coś w rodzaju pamiątki rodzinnej, niejednokrotnie przekazywanej z pokolenia na pokolenie, przechowywanej z sentymentu bądź na tzw. szczęście (np. Šimek 2010, 145; Hukantaival 2016, 182; Menšík 2018, 30-31).

Oznaką zanikania świadomości sakralnego znaczenia pradziejowych narzędzi kamiennych było praktyczne ich wykorzystanie (Menšík 2018, 22). Używano ich m.in. jako dusze do żelazka, ciężarki tkackie, świeczniki, wahadła zegarowe, młotki, odważniki, osełki czy kliny do łupania drewna (Reitinger 1976, 518; Blas de, Maya 1974, 215; Fröhlich 1992, 239-242; Fröhlich 2006; Sklenáŕ 1999, 62-64; Milošević 1998, 233, ryc. 379; Muhonen 2006, 10; Dowd 2018, 467, ryc. 12). Incydentalnie kamienne topory i siekiery były ponownie używane jako dziecięce zabawki (Hukantaival 2019, 358), wygładzacze płótna (Sheridan et al. 1992, 390; Dowd 2018, 467) ${ }^{47}$, motyki do karczowania krzaków (Berg, Maurer 2004, 248, ryc. 2:1) lub ogrzewacze do łóżek (Baudet 1907, 173). Jedna $z$ siekier znalezionych w Killamoat Upper pełniła funkcję klina utrzymującego otwarte drzwi stodoły (Rynne 1964-1965, 50-51).

Należy również wspomnieć, że już w średniowieczu kamienne wyroby pradziejowe mogły być wykorzystywane praktycznie. W traktacie rzemieślniczym De coloribus et artibus romanorum (źródło i jego poszczególne części datowane od X do XIII w.) przypisywanym Herakliuszowi mowa jest o sproszkowaniu i zmieszaniu zielonego szkła, spalonej miedzi (burnt cooper) i spalonych kamieni piorunowych (usti fulminis pulverem), które w połączeniu z rozdrobnionym przezroczystym szkłem używano jako zieloną glazurę do szkliwienia naczyń glinianych (Marrifield 1849, 204-205 [III, 1]). Przypuszcza się, iż takie właśnie przeznaczenie miała miniaturowa siekiera z klasztoru San Vincenzo al Volturno (Francis, Kline 2014, 402; Gilchrist 2019, 392).

Wreszcie dawne kamienie piorunowe mogły być zwyczajnie wyrzucone, tak jak to przypisuje się wspomnianym okazom z Großgoltern. Zdaniem E. Cosacka wraz z innymi odpadami zostały wyrzu-

47 Według G. Ramsey'a takie przeznaczenie miały polerowane siekiery odkrywane na stanowiskach wczesnośredniowiecznych, np. we wspomnianym Deer Park Farms (Ramsey 1995). W krótkiej polemice S. Penney zwrócił uwagę, że w ówczesnej Irlandii tego rodzaju przedmioty miały również ugruntowane znaczenie magiczne i używano ich jako talizmany (Penney 1995). 
cone na pryzmę z obornikiem, a następnie wraz z nim trafiły na pole, gdzie doszło do ponownego ich odkrycia (Cosack 2004, 63; zob. także Skutil 1932, 43; Reitinger 1976, 535). Niewykluczone, że taki właśnie los spotkał (może po jakimś okresie wtórnego użytkowania) siekierę znalezioną w późnośredniowiecznej latrynie ze Stargardu (Szeremeta 2019, 51).

\section{PODSUMOWANIE}

Kończąc należy stwierdzić, iż niniejszy artykuł daleki jest od wyczerpania zagadnienia dotyczącego sposobów wtórnego wykorzystania kamiennych wyrobów pradziejowych w średniowieczu i czasach nowożytnych, nie mówiąc już o okresach wcześniejszych. Już bowiem zaprezentowane źródła archeologiczne i pisane, dane etnograficzne oraz znaleziska przypadkowe ukazują szeroki repertuar możliwości posłużenia się tymi przedmiotami w przeszłości. Słusznie zauważa A.M. Labatt, że o ile topór użyty w charakterze pektorału unaocznia chrześcijański światopogląd wyrażający się praktyką noszenia dewocjonaliów, kamienie piorunowe wieszane na krokwiach sugerują już odmienny zestaw przekonań religijnych (Labatt 2018, 163). Tym niemniej kamienne wyroby znajdujące się w nowym kontekście, za sprawą swych właściwości materialnych i formalnych, aktywowały proces włączania ich do innej rzeczywistości, w uzgodnieniu $\mathrm{z}$ aktualną wiedzą i przekonaniami wierzeniowo-mitologicznymi. Wraz z nabywaniem nowych znaczeń przedmioty te uczestniczyły w ludzkich działaniach i relacjach, gdy celowo je poszukiwano, przekazywano i wykorzystywano w ramach aktualnie wyrażanego światopoglądu. Wynika to z przyjęcia koncepcji afordancji, najogólniej rozumianej jako interakcja między ludźmi a przedmiotami, z której biorą się wszelkie możliwości zastosowania ${ }^{48}$. $\mathrm{O}$ ile dany obiekt poprzez formę i materiał umożliwia pewne działania, od ludzi zależy jego wdrożenie uwarunkowane zdolnościami fizycznymi, umiejętnościami i wiedzą (szerzej na powyższy temat Bagley 2015).

Podjęta w niniejszej pracy wstępna próba skonfrontowania omawianych znalezisk $\mathrm{z}$ tradycyjnymi przekazami, ukazującymi je w konkretnych czyn-

48 W kwestii pojmowania, możliwości i ograniczeń wykorzystywania koncepcji afordancji w badaniach kultury materialnej zob. ostatnio m.in. Keßeler 2016; Davis, Chouinard 2017; Harwood, Hawezieh 2017; Jung 2018. nościach i zachowaniach o charakterze rytualnym i magicznym ${ }^{49}$, pokazuje, że mimo trudności w rozpoznawaniu ich znaczenia na podstawie kontekstów występowania oraz śladów bądź wtórnych zmian w wyglądzie, dokonywanych stosownie do aktualnych wymagań i potrzeb, dostrzec można pewne elementy powszechności i ciągłości związanych z nimi wyobrażeń, obserwowanych w dłuższej perspektywie czasowej. Wynikały one przede wszystkim z konieczności magicznej ochrony siebie i dobytku. Zarazem nadinterpretacją byłoby upieranie się przy chronologicznej niezmienności przypisywanych im sensów. Jak zauważył C. Houlbrook każdy z nich to a product not just of its anonymous prehistoric maker, but also of those finders, users, and relinquishers who pass through its biography (Houlbrook 2019, 200). Nie da się wszakże stwierdzić, czy istniały jakieś kryteria (np. okoliczności odkrycia, cechy fizyczne) przesądzajace o konkretnym zastosowaniu i przypisaniu funkcji omawianym przedmiotom. Zapewne uzależnione było to od doraźnych potrzeb bądź lokalnie utrzymującej się tradycji ${ }^{50}$. Jest to problem wymagający szerszego potraktowania i dalszych badań. Można jedynie stwierdzić, iż wiara w kamienie piorunowe sięga odległej przeszłości, zapewne kształtując się od momentu, gdy surowiec kamienny do produkcji narzędzi zaczął być wypierany przez metal. Wówczas to odchodzące $\mathrm{w}$ przeszłość topory i siekiery $\mathrm{z}$ kamienia stały się już „osobliwością” (zob. Klimscha, Nowak 2008). W średniowieczu i czasach późniejszych zyskały one dużą rangę, niewiele bowiem było przedmiotów, które po zaniku swej pierwotnej funkcji pozostawało w tak szerokim użyciu, znacznie wybiegającym poza tradycyjnie pojmowany recykling, na ogół ograniczający się do ponownego wykorzystania surowca i działań naprawczych (o tym np. Baumeister 2004; Fleming 2012; Biermann, Kersting 2017). Jako przedmioty o silnym ładunku sakralnym znalazły one bowiem trwałe miejsce w obrzędowości i wyobrażeniach dawnych społeczności.

$49 \mathrm{Na}$ temat możliwości wykorzystywania danych etnologicznych w archeologii zob. np. Gazin-Schwartz 2001.

50 Ten sam przedmiot mógł mieć kolejno różne przeznaczenie. Przykładowo, znaleziony we wsi Štrampouch (Czechy) siekieromłot z diorytu, początkowo umieszczany był w kalenicy dachu jako ochrona przed piorunami, następnie stosowano go przy leczeniu przepuklin $\mathrm{u}$ dzieci, aż wreszcie do zwiększenia mleczności krów (Sklenár 1999, 57). 


\section{BIBLIOGRAFIA}

\section{Źródla}

Albertus Magnus, Book of Minerals, przeł. i oprac. D. Wyckoff, Oxford 1967.

C. Plinii Secundi, Naturalis Historiae libri XXXVII 5, oprac. J. Sillig, Hamburgi-Gothae 1851.

De mineralibus et rebus metallicis libri quinque, auctore Alberto Magno summo Philosopho, Coloniae 1569.

Konrad von Megenberg, Buch der Natur, oprac. F. Pfeiffer, wyd. K. Aue, Stuttgart 1861.

Marbodi Liber Lapidum seu de Gemmis, oprac. J. Beckmann, wyd. J. Ch. Dieterich, Gottingae 1799.

\section{Opracowania}

Abramowicz A. (1979). Urny i ceruanie. Łódź: Ossolineum.

Aguirre Sorondo A.A. (2013). El rayo y el trueno en Euskalerria. Kobie. Antropología cultural, 17, 135-150.

Aladzhov D., Balabanyan D. (1972). Razkopki v s. Lyubenovo prez 1968 g. Rodopski sbornik, 3, 105-139.

Alonso Ramos J.A. (1993). Supersticiones y creencias en torno a las tormentas. Cuadernos de etnología de Guadalajara, 25, 143-182.

Andree R. (1889). Etnographische Parallelen und Vergleichen. Neue Folge. Leipzig: Verlag von Veit \& Comp.

Auerbach A. (1936). Ein Steinbeil als Blitzschuß. Der Spatenforscher, 1(4), 35.

Bagley J.M. (2015). Werkzeug, Prestigemarker, Kultobjekt und Ausstellungsstück - neolithische Steinbeile und -äxte im Wandel der Zeit. W: Ph.W. Stockhammer, H.P. Hahn (red.), Lost in Things - Fragen an die Welt des Materiellen (193-209). Münster-New York: Waxmann Verlag GmbH.

Banasiak P. (2017a). Znaleziska belemnitów z wczesnośredniowiecznego kompleksu osadniczego w Kałdusie. Próba interpretacji. Acta Universitatis Nicolai Copernici. Archeologia, 35, 69-100. doi: 10.12775/AUNC_ ARCH.2017.004.

Banasiak P. (2017b). Znaleziska belemnitów z wczesnośredniowiecznego Kałdusa. Antropologia kulturowa i jej znaczenie $\mathrm{w}$ interpretowaniu i zastosowaniu metod badawczych w archeologii. Młoda Muzeologia, 2, 6977. doi: 10.15584/mm.2017.2.6.

Banasiak P. (2018). Rola belemnitów w praktykach pogrzebowych na ziemiach polskich na przestrzeni dziejów. W: K. Kleczkowska, W. Kosior, A. Kuchta, I. Łataś (red.), Zwyczaje i akcesoria apotropaiczne w cywilizacjach świata (115-127). Kraków: AT Wydawnictwo.

Bargan A. (2015). The probable old germanic origin of Romanian iele '(evil) fairies'. Messages, Sages and Ages, 2(2), 13-18.

Barner W. (1957). Von Kultäxten, Beilzauber und rituellem Bohren. Die Kunde. N. F., 8(3-4), 175-186.

Barner W. (1968). Bauopfer und Hausschutzzauber im Land zwischen Hildesheimer Wald und Ith. Niedersachsen. Zeitschrift für Heimat und Kultur, 5, 236-266.

Bartels M. (1893). Beiträge zum Steinbeil - Aberglauben in Nord-Deutschland. Verhandlungen der Berliner anthropologischen Gesellschaft, 1893, 558-564.

Baudet P. (1907). Superstition populaire: A propos de deux haches trouvées dans une maison à Crécy-sur-Serre (Aisne). Bulletin de la Société préhistorique de France, 4(3), 170-173.

Baudouin M., Bonnemère L. (1904). Les haches polies dans l'histoire jusqu'au XIXe siècle. Bulletins et Mémoires de la Société d'anthropologie de Paris, 5(5), 496548.

Baumeister M. (2004). Metallrecycling in der Frühgeschichte. Untersuchungen zur technischen, wirtschaftlichen und gesellschaftlichen Rolle sekundärer Metallverwertung im 1. Jahrhtausend n. Chr. Rahden/ Westf.: Verlag Marie Leidorf.

Belaj V. (2007). Hod groz godinu. Pokušaj rekonstrukcije prahrvatskoga mitskoga svjetonazora. 2 wyd. Zagreb: Golden marketing - Technička knjiga.

Berg F., Maurer H. (2004). Die Sammlung Bauer: Archäologische Funde aus der Umgebung von Drosendorf. Das Waldviertel, 53, 229-254.

Beuker J. (1997). Donderstenen in het museum. Waardeel, 17(4), 20-24.

Biegeleisen H. (1929). Lecznictwo ludu polskiego. Kraków: Polska Akademja Umiejętności.

Biermann F., Kersting Th. (2017). Wiederverwendung oder „Recycling“ im früh- und hochmittelalterlichen nordwestslawischen Raum. W: R. von Schnurbein (red.), Altlust. 1000 Jahre Nachnutzung im Dom zu Brandenburg (12-23). Berlin: Verlag für Berlin-Brandenburg.

Birgisdottir B.B. (2001). 100-årsiden: Kuriositet fra yngre steinalder. SPOR, 16(31/1), 48-49.

Blas M.Á. de, Maya J.L. (1974). Hachas pulimentadas en castros asturianos. Boletín del Instituto de Estudios Asturianos, 28(81), 199-216.

Blas M.Á. de, Villa Valdés Á. (2007). La presencia no accidental de un hacha de talón en un fondo de hogar en 
el castro del Chao Samartín (Grandas de Salime, Asturias). W: J. Celis Sánchez (red.), El hallazgo leonés de Valdevimbre y los depósitos del Bronce Final Atlántico en la Península Ibérica (280-289). León: Junta de Castilla y León, Consejería de Cultura y Turismo: Diputación de León, Instituo Leonés de Cultura.

Blinkenberg Ch. (1911). The Thunderweapon in Religion and Folklore. A Study in Comparative Archaeology. Cambridge: University Press.

Boda G. (2017). Simbolistica Ielelor în mitologia românească. The Journal of Ethnology and Culturology, 21, 35-38.

Boges Th. (1910). Aus der Heidenzeit des braunschweigischen Landes. Braunschweig: Appelhans Verlag.

Borkowski J., Kuczkowski A. (2013). Poza szlakiem. Źródła archeologiczne do dziejów małych miast Pomorza Środkowego, część 1.B. woj. koszalińskie, Koszalin: Muzeum w Koszalinie.

Brumm A. (2018). Lightning teeth and Ponari sweat: Folk theories and magical uses of prehistoric stone axes (and adzes) in Island Southeast Asia and the origin of thunderstone beliefs. Australian Archaeology, 84(1), 37-55.

Brzozowska M. (1996). Kamień piorunowy. W: J. Bartmiński (red.), Stownik stereotypów i symboli ludowych, t. 1: Kosmos, cz. 1 (373-378). Lublin: Wydawnictwo Uniwersytetu Marii Curie-Skłodowskiej.

Bubenko T.S. (2004). Srednevekovyy Vitebsk. Posad Nizhniy zamok (X-pervaya polovina XIV v.). Vitebsk: Vitebskiy gosudarstvennyy universitet im. P.M. Masherova.

Burić T. (2015). „Strilni kamen” s Baba lokve / "Thunder stone" from Baba lokve site. Archaeologia Adriatica, 9(1), 351-364.

Busch M. (1877). Deutscher Volklglaube, 2. wyd. Leipzig: Verlag von Fr. Wilh. Krunow.

Cardoso J.L., Gonçalves M.I.R. (2020). Mercati, a Metallotheca Vaticana e as representações de artefactos pré-históricos na Europa do Renascimento. Estudos Arqueológicos de Oeiras, 26, 105-122.

Carelli P. (1996). Blixtar och dunder, magiska under. Om åskstenstraditionen och förekomsten av stenåldersfynd i medeltida kulturlager. Fornvännnen, 91, 153-170.

Carelli P. (1997). Thunder and Lightning, Magical Miracles. On the Popular Myth of Thunderbolts and the Presence of Stone Age Artefacts in Medieval deposits. W: H. Andersson, P. Carelli, L. Ersgård (red.), Visions of the Past. Trends and Traditions in Swedish Medieval Archaeology (393-417). Stockholm: Central Board of National Antiquites.
Cartailhac É. (1878). L’Âge de pierre dans les souvenirs et superstitions populaires. Paris: C. Reinwald \& $\mathrm{C}^{\mathrm{ie}}$, Libraires - Éditeurs.

Cederström R. (1920). Moderna stenvapen eller stenåldervapen?. RIG. Kulturhistorisk tidskrift, 3(1-2), 97-100.

Cherici A. (1989). Keraunia. Archeologia Classica, 41, 329-382.

Ciubotaru S. (2002-2003). Elemente magice legate de tratamentul hemoriniei. Anuar de lingvistică şi istorie literară, 42-43, 197-202.

Cosack E. (2004). Als die Steinbeile noch vom Himmel fielen. Archäologie in Deutschland, 1, 62-63.

Czaplicka M. (1985). Piorun w wierzeniach różnych ludów. Ziemia, 1985, 256-259.

Čermák K. (1907). Kamenné nástroje na Cáslavsku. Památky archeologické a místopisné, 22(7-8), 509-522.

Černecov A.V. (2002). K interpretacii unikal'nogo amuleta iz Kieva. Zhivaya starina, 1, 12-13.

Červinka I.L. (1897a). „Hromové kameny“ Pravěké nástroje v lidovém léčení. Časopis Společnosti prátel starožitností českých v Praze, 5(2), 46-49.

Červinka I.L. (1897b). „Hromové kameny“ Pravěké nástroje v lidovém léčení (Dokončení). Časopis Společnosti prátel starožitností českých v Praze, 5(3), 90-93.

Daunay J. (1978). La foudre et la tradition. Folklore de Champagne, 66, 3-10.

Davis J.L., Chouinard J.B. (2017). Theorizing Affordances: From Request to Refuse. Bulletin of Science, Technology\&Society, 36(4), 241-248. doi.org/10.1177/ 0270467617714.

Dejmal M., Kuča M., Přichystal A. (2018). Třebenice (k. ú. Plešice, okr. Třebíč). Hrad Holoubek. Neolit. Náhodný nález kamenné industrie. Ověřovací výzkum. Přehled výzkumů, 59(1), 140.

Demnard F., Néraudeau D. (2001). L'utilisation des oursins fossiles de la Préhistoire à l'epoque gallo-romaine. Bulletin de la Société préhistorique française, 98(4), 693-715.

Demuth V. (2002). Ein „Donnerkeil” aus Groß Steinum am Dorm (Landkreis Helmstedt). Neolitisches Steingerät als Zeugnis frühneuzeitlichen Volksglaubens. Die Kunde N.F., 53, 109-116.

Doušek R. (2011). Magické předměty na moravském venkově. W: A. Kř́žzová a kolektiv (red.), Archaické jevy tradični kultury na Moravě (161-176). Brno: Masarykova univerzita.

Dowd M. (2018). Bewitched by an Elf Dart: Fairy Archaeology, Folk Magic and Traditional Medicine in Ireland. Cambridge Archaeological Journal, 28(3), 1-23. 
Durdík T. (1997). „Hromový klín“ z hradu Křivoklátu. Sbornik Kruhu přátel muzea hl. m. Prahy, 1, 107110.

Durdík T. (2007). Hrady přechodného typu v Čechách. Praha: Agentura Pankrác.

Eijk G. van (2007). De dondersteen van Uden. Een neolithische bijl uit een middeleeuwse waterput. Westerheem, 56(4), 208-216.

Eijk G. van (2008). De dondersteen van Uden. Een neolithische bijl uit een middeleeuwse waterput. Westerheem, 57(3), 170-172.

Eliade M. (1993). Kowale i alchemicy. Warszawa: Fundacja Aletheia.

Ellis Davidson H.R. (1965). Thor's Hammer. Folklore, 76, 1-15.

Elsworth D.W., Boughton D. (2016). Prehistoric finds from Slackwood farm, Silverdale. Contrebis, 34, 8-12.

Erich O.A., Beitl R. (1955). Wörterbuch der deutschen Volkskunde. 2. wyd. Stuttgart: Alfred Kröner Verlag.

Ermischer G. (2006). Hier liegt der Hund begraben. W: H. Rosmanitz (red.), Die Ketzelburg in Haibach. Eine archäologisch-historische Spurensuche (99-102). Neustadt a.d. Aisch: Verlag Schmidt.

Evans J. (1897). The stone implemenst, weapons and ornaments of Great Britain. London - Bombay: Longmans, Green and Co.

Faraone Ch.A. (2014). Inscribed Greek Thunderstones as House- and Body-Amulets in Roman Imperial Times. Kernos, 27, 251-278.

Farkaš M., Gregor M. (2016). K otázke niektorých kamenných brúsených nástrojov z Bratislavy-Devína. Zborník Slovenského národného múzea. Supplementum, 11, 35-43.

Feiken H., Knol E. (2006). Stenen bijlen uit de Groninger klei. Paleo-Aktueel, 17, 75-81.

Fleming R. (2012). Recycling in Britain after the fall of Rome's metal economy. Past and Present, 217(1), $3-45$.

Fojtík A., Popelka M. (2018). Litenčice (okr. Kroměříž). Přehled výzkumů, 59(1), 132.

Francis K., Kline M.Ph. (2011). Prehistoric Stone Tools in Medieval Contexts. W: S. Leppard, J. Mitchell, E.G. Clark, K. Francis, Ph. Kline (red.), San Vincenzo Maggiore and its Workshops (397-410). London: British School at Rome.

Franz A. (1909). Die kirchlichen Benediktionen im Mittelalter 2. Freiburg im Breisgau: Herdersche Verlagshandlung.

Fröhlich J. (1992). Hromové klíny v jižních Čechách. Výběr z prací členů Historického klubu při Jihočeském muzeu v Českých Budéjovicích, 29, 237-245.
Fröhlich J. (2006). Druhotné použití eneolitické sekery. Výběr z prací členů Historického klubu při Jihočeském muzeu v Českých Budějovicích, 43(3), 238-239.

Fröhlich J. (2015). Královské město Písek z pohledu archeologa. Putim: Nakladatelství Blanice

García Castro J.A. (1988). Mitos y creencias de origen prehistórico: «Las Piedras de Rayo». Espacio, Tiempo y Forma, Serie I: Prehistoria, 1, 427-443.

Gasanov B.A. [Bogumil Wlch.]. (2018). "Gromovye strely" $i$ "tchertovy pal'cy": magitcheskie praktiki $v$ tradicii slavyan. Moskva: Svet.

Gaudant J. (2007). Aux sources de la Préhistoire : les céraunies, ces pierres étranges supposées tombées du ciel. Travaux du Comité français d'Histoire de la Géologie, Comité français d'Histoire de la Géologie, 21(2, 3ème série), 97-112.

Gazin-Schwartz A. (2001). Archaeology and Folklore of Material Culture, Ritual, and Everyday Life. International Journal of Historical Archaeology, 5(4), 263280.

Geupel V. (1987). Ein Bauopfer aus Pockau, Kr. Marienberg. Ausgrabungen und Funde, 32(1), 2-5.

Ghinoiu I. (2013). Iele. In: tegoż, Mitologie română. Dicţionar (141-143). Bucureşti: Editura Univers Enciclopedic Gold.

Gilchrist R. (2019). Magic and Archaeology: Ritual Residues and "Odd" Deposits. W: S. Page, C. Rider (red.), The Routledge History of Medieval Magic (383-401). Abingdon: Routledge.

Giligny F., Bostyn F., Le Maux N. (2012). Production et importation de haches polies dans le Bassin parisien: typologie, chronologie et influences. W: P. Pétrequin, S. Cassen, M. Errera, L. Klassen, A. Sheridan, A.-M. Pétrequin (red.), JADE. Grandes haches alpines $d u$ Néolithique européen, Ve et IVe millénaires av. J.-C. 2 (1136-1167). Besançon: Presses universitaires de Franche-Comté, Centre de Recherche Archéologique de la Vallée de 1'Ain.

Gjerpe L.E. (red.). (2005). Gravfeltet på Gulli. E18prosjektet Vestfold Bind 1. Oslo: Kulturhistorisk Museum, Fornminneseksjonen, Universitetet i Oslo.

Goodrum M.R. (2002). The meaning of ceraunia: archaeology, natural history and the interpretation of prehistoric stone artefacts in the eighteenth century. British Journal for the History of Science, 35, 255269.

Goodrum M.R. (2008). Questioning Thunderstones and Arrowheads: The Problem of Recognizing and Interpreting Stone Artifacts in the Seventeenth Century. Early Science and Medicine, 13, 482-508. 
Goodrum M.R. (2011). Recovering the Vestiges of Primeval Europe: Archaeology and the Significance of Stone Implements, 1750-1800. Journal of the History of Ideas, 72(1), 51-74.

Graudonis J. (1983). Altene. Arheologija un etnogrāfija, $14,40-85$.

Grønbeck I.A. (2016). En gave fra gudene? Frá haug ok heiðni, 4, 19-22.

Grünzweig F.E. (2004). Runeninschriften auf Waffen: Inschriften vom 2. Jahrhundert n. Chr. bis ins Hochmittelalter. Wien: Edition Praesens.

Hadarnik Cz. (2000). Zdobiony toporek ślężański z BuskaZdroju, woj, świętokrzyskie. Sprawozdania Archeologiczne, 52, 143-150.

Hála J. (2016a). Alföldi adatok a „,mennykövek”-ről. W: tegoż, Különös kövek, csodás csontok. Kilenc dolgozat a népi geológia köréböl (41-68). Rudabánya: Érc- és Ásványbányászati Múzeum Alapítvány.

Hála J. (2016b). Ásványokkal és kőzetekkel kapcsolatos néprajzi adatok a Börzsönyből és környékéröl. W: tegoż, Különös kövek, csodás csontok. Kilenc dolgozat a népi geológia köréből (85-108). Rudabánya: Érc- és Ásványbányászati Múzeum Alapítvány.

Hall M.A. (2005). Burgh mentalities: a town-in-the-country case study of Perth, Scotland. W: K. Giles, C. Dyer (red.), Town and Country in the Middle Ages: contrasts, contacts and interconnections, 1100-1500 (211228). Leeds: Maney Publishing.

Hammarstedt N.E. (1920). Svensk forntro och folksed i bild och ord. Stockholm: Nordiska Musset.

Hammarstedt N.E. (1925). Donnerkeil. W: M. Ebert (red.), Reallexikon der Vorgeschichte 2 (444-448). Berlin: Verlag Walter de Gruyter \& Co.

Harwood S.H., Hafezieh N. (2017). ,Affordance“ - what does this mean? W: Conference: 22nd UKAIS Annual Conference, St Catherine's College Oxford, UK. [https://www.researchgate.net/publication/32377 3021_\%27Affordance\%27___what_does_this_mean] - dostęp dn 31.03.2020.

Hegele A. (1997). Donnerkeil und Teufelsfinger (Belemniten in Volksglauben und Volksmedizin). Fossilien, 14(1), 21-26.

Heidelk-Schacht S. (1983). "Donnerkeile" aus dem Bezirk Neubrandenburg. Ausgrabungen und Funde, 28(3), 105-109.

Heintel H. (1961). Blitzschutz und Beilzauber. Fundberichte aus Hessen, 1, 129-130.

Hell M. (1959). Steinbeile als Bauopfer aus Oberösterreich. Archaeologia Austriaca, 26, 96-99.

Hell M. (1962). Neue jungsteinzeitliche Funde aus dem Lande Salzburg. Archaeologia Austriaca, 32, 27-34.
Hell M. (1964). Alter Schutz- und Segensbrauch (Bauopfer) im salzburgischen Flachgau. Mitteilungen der Gesellschaft für Salzburger Landeskunde, 104, 271-300.

Helwing G.A. (1717). Lithographia Angerburgica. Regiomonti: Literis Johannis Stelteri.

Hložek J., Menšík P. (2009). „Hromové klíny“ z Kozího hrádku na Táborsku aneb „Účinné“ zajištění hradu před př́rodní pohromou, nebo starší pravěké sídliště? Kuděj, 1, 63-73.

Hložek J., Menšík P. (2014a). Př́spěvek $k$ interpretaci broušeného artefaktu z hradu Týrova. Archeologie západních Čech, 7, 46-50.

Hložek J., Menšík P. (2014b.) Pravěké „zbraně“ jako symbol ochrany ve středověku a novověku. W: A. Lukešová (red.), Život je boj? Nezbytnost konfliktů v přirodě, společnosti a vědě. Sbornik abstraktů a př́spěvků z 15. Výjezdního interdisciplinárního semináře v Nečtinech 20.-23. ledna 2014 (107-109). Plzeň: Západočeská univerzita v Plzni.

Hložek J., Menšík P., Procházka M. (2015). Bauopfer im mittelalterlichen Böhmen. Fines Transire, 24, 271280.

Hoffmann-Krayer E. (1921). Aberglaube. W: H. Türler, M. Godet, V. Attinger (red.), Historisch-biographisches Lexikon der Schweiz 1 (55-60). Neuenburg: Administration des Historisch-Biographischen Lexikons der Schweiz.

Hoggart B. (2004). The archaeology of counter-witchcraft and popular magic. W: O. Davies, W. de Blécourt (red.), Beyond the Witch Trials. Witchcraft and Magic in Enlightenment Europe (167-186). Manchester, New York: Manchester University Press.

Høiris O. (2015). Om tordenkiler, stenøkser og uddøde dyr. KUML, 2015, 9-48.

Höltker G. (1944). Der Donnerkeilglaube vom steinzeitlichen Neuguinea aus gesehen. Acta Tropica, 1(1), 30-51.

Holtorf C. (2015). From Stonehende to Las Vegas. Archaeology as Popular Culture. Walnut Creek-Lanham-New York-Toronto-Oxford: AltaMira Press.

Horn Fuglesang S. (1989). Viking and medieval amulets in Scandinavia. Fornvännen, 84, 15-27.

Horoszkiewicz R. (1950). Toporki neolityczne w lecznictwie ludowym na Opolszczyźnie. Z Otchłani Wieków, 19(9-10), 159-160.

Houlbrook C. (2019). 'The Stone Axe from Way Back': A Mutable Magical Object in Folklore and Fiction. Folklore, 130(2), 192-202. doi: 10.1080/0015587X. 2018.1515291.

Hraše J.K. (1898). Hromové klíny aneb kameny. Český lid, 7, 82-83. 
Hukantaival S. (2016). "For a Witch Cannot Cross Such a Threshold!" Building Concealment Traditions in Finland c. 1200-1950. Archaeologia Medii Aevi Finlandia 23, Turku: Suomen keskiajan arkeologian seura.

Hukantaival S. (2018). The Materiality of Finnish Folk Magic: Objects in the Collections of the National Museum of Finland. Material Religion, 14(2), 183-198.

Hukantaival S. (2019). Ukonvaajojen monet kasvot - Luokittelu- ja tulkintakysymyksiä. W: J. Harjula, V. Immonen, J. Ruohonen (red.), Puukenkien kopinaa. Henrik Asplundin juhlakirja (345-381). Turku: Turun yliopisto.

Ivakin G.Yu. (2002). Khristianskaya podveska-amulet iz Kieva. Zhivaya starina, 1, 9-11.

Ivakin G. (2007). Excavations at St. Michael Golden Domes Monastery in Kiev. W: A. Aibabun, G. Ivakin (red.), Kiev - Cherson - Constantinople. Ukrainian Papers at the XXth International Congress of Byzantine Studies (Paris, 19-25 August 2001) (177-220). Kiev-Simferopol-Paris: Ukrainian National Committee for Byzantine Studies.

Ivakin G.Yu., Chernetsov A.V. (2001). Unikal'nyy amulet iz Zlatoverkhogo. Drevniy mir, 2, 36-38.

Ivakin G.Yu., Chernetsov A.V. (2002). Unikal'nyj amulet iz raskopok v Kieve. W: A.L. Toporkov, A.A. Turilov (red.), Otrechennoye chteniye v Rossii XVII-XVIII vekov (521-532). Moskva: Indrik.

Ivakin G.Yu., Putsko V.H. (2005). Pamyatnyky plastychnoho mystetstva z rozkopok verkhn'oho Kyyeva 19982001 rr. Arkheolohiya, 4, 94-107.

Jacobs J. (1991). Die Einzelgrabkultur in MecklenburgVorpommern. Berlin: Archäologisches Landesmuseum Mecklenburg-Vorpommern.

Jensen O.W. (2000). The Many Faces of Stone Artefacts: A Case Study of the Shift in the Perception of Thunderbolts in the Late 17th and Early 18th Century. W: O.W. Jensen, H. Karlsson (red.), Archaeological Conditions. Examples of Epistemology and Ontology (129143). Göteborg: Göteborg University.

Jesse C. (1973). Pre-Columbian Stone Artifacts put to Strange Uses. W: Proceedings of the Fourth International Congress for the Study of Pre-Columbian Cultures of the Lesser Antilles. Reduit Beach, St. Lucia, July 26-30, 1971 (68-72). St. Lucia: St. Lucia Archaeological and Historical Society Castries.

Johanson K. (2006). The contribution of stray find for studying everyday practice - the example of stone axes. Estonian Journal of Archaeology, 10(2), 99-131.

Johanson K. (2009). The changing meaning of 'thunderbolts'. Folklore. Electronic Journal of Folklore, 42, 129-174.
Johanson K. (2018a). Missing interpretations. Natural and residual finds in Estonian archaeological collections. Tartu: University of Tartu.

Johanson K. (2018b). Missing interpretations: tracing natural artefacts in Estonian archaeological material. Fennoscandia archaeologica, 35, 87-106.

John J. (2003). O lidech (minulých) a fosíliích (ještě minulejších). Sbornik Muzea středního Posázavi v Ratajích nad Sázavou a Archeologické společnosti při Katedře archeologie Západočeské univerzity v Plzni, 2, 15-20.

Jung M. (2018). Das objektepistemologische Potential des Affordanzkonzeptes James Gibsons und seine Bedeutung als Grundlage von ,Objektbiographien“. Methodologische Anmerkungen und exemplarische Fallstudie. W: M. Hilgert, K.P. Hofmann, H. Simon (red.), Objektepistemologien. Zur Vermessung eines transdisziplinären Forschungsraums (135-178). Berlin: Edition Topoi.

Kaczorowski R. (2003). Przesądy i wierzenia w ludowej kulturze polskich mieszkańców Warmii na przełomie XIX i XX wieku. Studia Elbląskie, 5, 93-103.

Kajkowski K. (2019). Obrzędowość religijna Pomorzan we wczesnym średniowieczu. Studium archeologiczne. Wrocław: Wydawnictwo Chronicon.

Kalábek M. (2001). Karlův hrad. W: Archeologie zrcadlení (114-118). Olomouc: Vlastivědné muzeum v Olomouci.

Kaufmann D. (1936). Vorgeschichtliche Steinwerkzeuge im Volksglauben. Der Spatenforscher, 1(4), 29-35.

Kalseth J. (2010). Steinøks eller torndenkile. Spor, 25(2), 28-30.

Keßeler A. (2016). Affordanz, oder was Dinge können! W: K.P. Hofmann, T. Meier, D. Mölders, S. Schreiber (red.), Massendinghaltung in der Archäologie. Der Material Turn und die Ur- und Frühgeschichte (343363). Leiden: Sidestone Press.

Kharuzin N.N. (1894). Iz materialov, sobrannykh sredi krest'yan Pudozhskogo uyezda Olonetskoy gubernii. Olonetskiy sbornik. Materialy dlya istorii, geografii, statistiki i etnografii Olonetskogo kraya, 3, 302-346.

Kirchner E. (1853). Thor's Donnerkeil und die steinernen Opfergeräte des nord-germanischen Heidenthums. Neu-Strelitz: Verlag der Hofbuchhandlung von G. Barnewitz.

Kjellmark K., Thordeman B. (1939). Hällkistan och myntskatten från Rappe i Öjaby socken, Småland. Fornvännnen, 1939, 65-89.

Klassen L. (2004). Jade und Kupfer. Untersuchungen zum Neolithisierungsprozess im westlichen Ostseeraum besonderer Berücksichtigung der Kulturentwicklung 
Europas 5500-3500 BC. Århus: Aarhus University Press.

Klecanda J. (1901). Hromové kameny (předhistorické mlaty) v XV. a XVI věku. Český lid, 10, 214-215.

Klimscha F, Nowak K. (2008). „Donnerkeile“ - Die (post) neolithische Verwendung steinerner Beile als Talisman, Medizin und Co. Museumsjournal Natur und Mensch, 4, 31-43.

Knight M.G., Boughton D., Wilkinson R.E. (2019). Objects of the Past in the Past. W: M.G. Knight, D. Boughton, R.E. Wilkinson (red.), Objects of the Past in the Past Investigating the significance of earlier artefacts in later contexts (1-18). Oxford: Archaeopress Publishing Ltd.

Koledinskiy L.V. (2020). Mirovospriyatiye i mirooshchushcheniye zhiteley Vitebska v XII-XVIII vv. (po materialam raskopok Verkhnego zamka). W: A.M. Avlasovich (red.), Kopytinskiye chteniya 3. Sbornik statey Mezhdunarodnoynauchno-prakticheskoy konferentsii, Mogilev, 28 fevralya - 1 marta 2019g. (4-11). Mogilev: Mogilevskiy gosudarstvennyy universitet im. A.A. Kuleshova.

König A. (1994). Die archäologischen Funde der Rathausgrabung in Höxter aus den Jahren 1988 bis 1992. Ein erster Überblick. W: G.U. Großmann (red.), Das Rathaus in Höxter (151-196). München-Berlin: Deutscher Kunstverlag.

Korpikiewicz H. (2016). Symbolika i kult: meteory i meteoryty. Lingua ac communitas, 26, 15-29.

Kościński B., Paner H. (2005). Nowe wyniki datowania grodu gdańskiego - stanowisko 1 (wyk. I-V). W: H. Paner, M. Fudziński (red.), XIV Sesja Pomorzoznawcza 2: od wczesnego średniowiecza do czasów nowożytnych (11-47). Gdańsk: Muzeum Archeologiczne w Gdańsku.

Koštuřík P., Kovárník J., Měřínský Z., Oliva M. (1986). Pravěk Třebičska. Brno: Muzejní a vlastivědná společnost (Brno), Západomoravské muzeum (Třebíč).

Koudelka F. (1882). Die Donnersteine als Medicin bei den mährischen Slaven. Mittheilungen der Anthropologischen Gesellschaft in Wien, 12 (NF 2), 159-160.

Kowalski P. (1998). Leksykon znaki świata. Omen, przesad, znaczenie. Warszawa, Wrocław: Wydawnictwo Naukowe PWN.

Kowalski K., Matuszewska A. (2012). Wprowadzenie do problematyki kulturowej zabytków neolitycznych / The Cultural Issues of the Neolithic Antiquities: an Introduction. W: K. Kowalski, D. Kozłowska-Skoczka (red.), Zaginione - ocalone. Szczecińska kolekcja starożytności pomorskich / Lost-Saved. The Pomera- nian Antiquities Collection of Szczecin (69-79). Szczecin: Muzeum Narodowe w Szczecinie.

Krival'tsevich N.N. (1992). Kul't kamiennych siakier na Bielarusi. W: M.P. Kasciuk, M.V. Bič, H.V. Štychaŭ (red.), Staronki historyi Bielarusi (7-12). Minsk: Navuka i tekhnika.

Kulmar T. (2005). On Supreme Sky God from the Aspect of Religious History and in Prehistoris Estonian Materials. Folklore, 31, 15-30.

Kunnas-Pusa L. (2016). Tärvellyt ja kaaputetut - Kivikautiset irtolöydöt Jaakkiman pitäjästä ja kivikauden esineiden keräily 1800-1900-lukujen vaihteessa. Muinaistutki, 4, 2-17.

Kurasiński T., Skóra K. (2020). From the past into the future - archaica as a research problem (on the basis of medieval and modern period finds from CentralEastern Europe) / Z przeszłości w przyszłość - archaika jako problem badawczy (na podstawie średniowiecznych i nowożytnych materiatów z Europy Środkowo-Wschodniej). W: M. Bogucki, A. Dymowski, G. Śnieżko (red.), Silvers of the Antiquity. The Use of Ancient Coins in Central, Eastern and Northern Europe in the Medieval and Modern Periods / Okruchy starożytności. Użytkowanie monet antycznych $w$ Europie Środkowej, Wschodniej i Pólnocnej w średniowieczu $i$ w okresie nowożytnym (301-366). Warszawa: Wydawnictwa Uniwersytetu Warszawskiego.

Labatt M.A. (2018). Turning an Axe on Its Head. A Journal of Decorative Arts, Design History and Material Culture, 25(2), 160-175.

Lagercrantz S. (1940). Der Donnerkeil im Afrikanischen Volksglauben. Etnologiska Studier, 10, 1-40.

Lapshin V.A. (2009). Tver'v XIII-XIV vv. (po materialam raskopok 1993-1997 gg.). Sankt-Peterburg: Fakul'tet filologii i iskusstv Sankt-Peterburgskogo gosudarstvennogo universiteta.

Larocca F., Breglia F. (2016). Grooved stone tools from Calabria region (Italy): Archaeological evidence and research perspectives. Journal of Lithic Studies, 3(3), 301-312.

Laurinkienè N. (1996a). Perkūnkulkè - griaustinio dievo ženklas. Liaudies kultūra, 1, 23-26.

Laurinkienè N. (1996b). Senovès lietuviu dievas Perkūnas. Kalboje, tautosakoje, istor iniuose šal tiniuose. Vilnius: Lietuvių literatūros ir tautosakos institutas.

Lech J. (1992). Prehistoria i przemiany światopoglądowe w Europie. Archeologia Polski, 37(1-2), 265-285.

Lebeda A. (2002). Wiedza i wierzenia ludowe. WrocławCieszyn: Polskie Towarzystwo Ludoznawcze. 
Lehtosalo-Hilander P.-L. (2000). Luistari - A History of Weapon and Ornaments. Helsinki: Suomen Finska fornminnesföreningen.

Lepówna B. (1981). Materialne przejawy wierzeń ludności Gdańska w X-XIII w. Pomorania Antiqua, 10, 169199.

Lequellec J.-L. (1996). Mégalithes et traditions populaires. La hache et le marteau de vie et de mort. Bulletin de la Société préhistorique française, 93(3), 287-297.

Libera Z. (2003). Znachor $w$ tradycjach ludowych i popularnych XIX-XX wieku. Wrocław: Towarzystwo Przyjaciół Ossolineum.

Lindow J. (1994). Thor's hammar. The Journal of English and Germanic Philology, 93(4), 485-503.

Lødøen T.K. (1993). Tor-steinen. Arkeo. Nytt fra Historisk Museum i Bergen, 1, 32.

Lovisato D. (1878). Di alcune azze, scalpelli, martelli e ciottoli dell'epoca della pietra trovati nella Provincia di Catanzaro. Bollettino della Societa Adriatica di Scienze Naturali in Triste, 3, 475-505.

Lozhkina Ye.V. (2005). "Chertovy pal'tsy" ("vumurt chin'y”) v narodnom tselitel'stve udmurtov. W: Fol'klor i postfol'klor: struktura, tipologiya, semiotika: Vesennyaya sokola - 2005. [http://www.ruthenia.ru/folklore/ lozhkina1.htm] - dostęp 15.05.2020.

Łapo J.M. (2008). Ludowa wizja przeszłości Mazur. Stanowiska archeologiczne $i$ miejsca o znaczeniu historycznym na dawnym pograniczu galindzko-jaćwieskim w świadomości Mazurów (XVI w. - I połowa XX w.). Olsztyn: Ośrodek Badań Naukowych im. Wojciecha Kętrzyńskiego w Olsztynie.

MacLeod M., Mees B. (2006). Runic Amulets and Magic Objects. Woodbridge: The Boydel Press.

Makushnikov O.A. (2009). Gomel'skoye Podneprov'ye $v V$ - seredine XIII vv. Sotsial'no - ekonomicheskoye i etnokul 'turnoye razvitiye. Monografiya. Gomel': Gomel'skiy gosudarstvennyy universitet im. Frantsiska Skoriny.

Malakhova A.S. (2009). "Gromovye strely" v narodnô religioznosti terskikh Kazakov (tersko-severoruskie paralleli). W: Yu.A. Prokopenko, A.A. Durov (red.), Iz istorii kul'tury narodov severnogo Kavkaza 1 (6975). Stavropol': Izdatelstvo Grafa.

Marrifield M.P. (1849). Original Treatises, dating from the XIIth to XVIIIth Centuries on the Arts of Painting, in Oil, Miniature, Mosaic, and on Glass; of Gilding, Dyeing, and the Preparation of Colours and Artificial Gems 1. London: John Murray, Albemarle Street.

Maurer H. (2012). Ein Donnerkeil von Zitternberg bei Gars am Gamp, BH Horn, Niederösterreich. Unsere Heimat, 83(3-4), 241-243.
Mazurkiewicz M. (1991). Kamień piorunowy w polszczyźnie i kulturze ludowej (Szkic do Słownika ludowych stereotypów językowych). W: J. Anusiewicz, J. Bartmiński (red.), Język i kultura 1: Podstawowe pojęcia i problemy (149-155). Wrocław: Wiedza o Kulturze.

McNamara K.J. (2007). Shepherds' crowns, fairy loaves and thunderstones: the mythology of fossil echinoids in England. W: L. Piccardi, W.B. Masse (red.), Myth and Geology (279-294). London: Geological Society of London.

Medunová-Benešová A. (1997). Neolithikum und Äneolithikum. W: L. Poláček (red.), Studien zum Burgwall von Mikulčice 2 (293-146). Brno: Archeologický ústav AV ČR, Brno.

Mehling A. (1998). Archaika als Beigaben. Studien an merowingerzeitlichen Gräberfeldern. Rahden/Westfalen: Verlag Marie Leidorf GmbH.

Meinecke M. (2014). Cerauniae - Donnerkeile. W: U. Veit, M. Wöhrl (red.), Donnerkeil - Opfermesser - Thrängefäß. Die archäologischen Objekte aus der Sammlung der Leipziger Apothekerfamilie Linck (1670-1807) im Naturalienkabinett Waldenburg (Sachsen) (49-51), Lepzig: Professur für Ur- und Frügeschichte.

Menšík P. (2010a). Nálezy broušené kamenné industrie v mladších pravěkých kulturách v jižních a západních Čechách. Časopis společnosti pratel starožitností, 118(2), 20-26.

Menšík P. (2010b). Zhodnocení neolitického a eneolitického osídlení Českokrumlovska. Stručná charakteristika vývoje v jižních Čechách. Acta Fakulty filozofické Západočeské univerzity v Plzni, 4, 27-47.

Menšík P. (2014). „Hromové klíny“ ze sbirky Národopisnégo oddělení Západočeského muzea v Plzni. Časopis společnosti přatel starožitností, 122(3), 156-159.

Menšík P. (2018). Nový nález „hromového klínu“ ze Železné Rudy, okr. Klatovy. Archeologie západnich Čech, 9(1), 29-31.

Mercati M. (1717). Metallotheca Vaticana. Romæ: Typographum Vaticanum.

Merrifield R. (1987). The Archaeology of Ritual and Magic. London: New Amsterdam Books.

Merta D. (2013). Hromový klín. [www.archaiabrno.org/ home_cs/?acc $=$ zapisnicek\&blog_id $=601 \&$ blog_date =2013-11-12] - dostęp dn. 20.04.2020.

Mildenberger G. (1969). Verschleppte Bodenfunde. Ein Beitrag zur Fundkritik. Bonner Jahrbücher, 169, 1-28.

Milošević A. (1998). Arkeološka topografija Cetine. Split: Muzej hrvatskih arheoloških spomenika.

Mitmannsgruber A. (1962). Ein Donnerkeil im niederösterreichischen Mostviertel. Österreichische Zeitschrift für Volkskunde, 65(NS 16), 177. 
Modderman P.J.R. (1964). Stenen bijl met ijzeren schachthuls uit de Waal bij Nijmegen, Berichten van de rijksdienst voor het oudheidkundig bodemonderzoek, 14, 69-73.

Montelius O. (1906). Kulturgeschichte Schwedens von den ältesten Zeiten bis zum elften Jahrhundert nach Christus. Leipzig: Verlag von E.A. Seemann.

Moszyński K. (1967). Kultura ludowa Słowian 2: Kultura duchowa 1. Warszawa: Książka i Wiedza.

Motz L. (1997). The germanic thunderweapon. Saga-Book, 24, 329-350.

Mugurēvičs Ē. (1977). Oliņkalna un Lokstenes pilsnovadi. 3.-15. gs. arheologiskie pieminekļi. Rīga: Zinātne.

Muhonen T. (2006). Kolme ajallista näkökulmaa ukonvaajoihin. Kivikauden kiviesineet myöhempien aikojen kuriositeetteina. Kuriositeettikabi.net, 3, 1-23.

Musin A.E. (2005). Milites Christi Drevney Rusi. Voinskaya kul'tura russkogo srednevekov'ya v kontekste religioznogo mentaliteta. Sankt-Peterburg: Peterburgskoye Vostokovedeniye.

Musin A.E., Żeltowa M.N., Tarabardina O., Tianina E.A. (2018). Kamienne artefakty z epoki neolitu i wczesnej epoki żelaza jako amulety średniowiecznego Nowogrodu. W: S. Rosik, S. Jędrzejewska, K. Kollinger (red.), Hierofanie, wierzenia, obrzędy... Kultura symboliczna $w$ średniowieczu między pogaństwem a chrześcijaństwem (13-41). Rzeszów: Wydawnictwo Uniwersytetu Rzeszowskiego.

Norkus J. (1959). Ein „Donnerkeil” und ein Schalenstein aus dem Kreise Hameln-Pyrmont. Die Kunde N.F., 10 (3-4), 219-220.

Novotný B. (1991). Hromový klin z Lúčnice nad Žitavou. Archeologické výskumy a nálezy na Slovensku v roku 1989, 73.

Nedoshivina N.G. (1976). O religioznykh predstavleniyakh vyatichey XI-XIII vv. W: G.K. Vagner, D.S. Likhachev, P.A. Rappoport (red.), Srednevekovaya Rus'. Moskva: Nauka.

Norkus J. (1959). Ein „Donnerkeil” und ein Schalenstein aus dem Kreise Hameln-Pyrmont. Die Kunde N.F., 10(3-4), 219-220.

Novotný B. (1991). Hromový klin z Lúčnice nad Žitavou. W: O. Oždáni, M. Rejholcová (red.), Archeologické výskumy a nálezy na Slovensku v roku 1989 (73). Nitra: Archeologický ústav Slovenskej akadémie vied v Nitre.

O'Sullivan A. (2017-2018). Magic in early medieval Ireland: Some observations from archaeological evidence. Ulster Journal of Archaeology, 74, 107-117.
Ofrim A. (2019). Attitudes towards prehistoric objects in Romanian folk culture (19 $19^{\text {th }}-20^{\text {th }}$ century). Swedish Journal of Romanian Studies, 2(1), 92-109.

Olbrich K. (1987). Donnerkeil. W: H. Bächtold-Stäubli, E. Hoffmann-Krayer (red.), Handwörterbuch des deutschen Aberglaubens 2 (325-331). Berlin-New York: Walter de Gruyter.

Palliardi J. (1889). Zažehnávání hromovým kamenem. Časopis Vlastivědného spolku muzejního v Olomouci, 6(22), 87.

Paulsen P. (1939). Axt und Kreuz bei den Nordgermanen. Berlin: Ahnenberge-Stiftung-Verlag.

Pedrosa J.M. (2009). Jussieu, Feijoo y las piedras del rayo, o la razón moderna frente a la vieja superstición. Revista Murciana de Antropología, 16, 245-270.

Penney S.H. (1976). Axes, Arrowheads and Other Antiquities in Irish Folklore. Ulster Folklife, 22, 70-75.

Penney S.H. (1995). Stone Axes in Early Christian Contexts. Archaeology Ireland, 9(3), 50.

Plessingerová A., Vařeka P. (1999). Bouře, hromový kámen v lidových představách, víre a obyčejích. W: L. Tarcalová (red.), Kult a živly (207-213). Uherské Hradiště: Slovácké muzeum v Uherském Hradišti.

Pokrovskiy F.V. (1899). Arkheologicheskaya karta Kovenskoy gubernii. Vil'na: Tipogrfiya A.G. Syrkina.

Pollex A. (2010). Glaubenvorstellungen im Wandel. Eine archäologische Analyse der Körpergräber des 10. bis 13. Jahrhunderts im nordwestslawischen Raum. Rahden/Westf:: Verlag Marie Leidorf GmbH.

Profantová N. (2005). Kamenné artefakty. W: M. Kuna, N. Profantová a autorský kolektiv (red.), Počátky raného středověku v Čechách. Archeologický výzkum sidelni aglomerace kultury pražského typu v Roztokách (202-207). Praha: Archeologický ústav AV ČR Praha.

Pyvovarov S.V. (2008). Vikoristannya arkheolohichnikh artefaktiv u mahichniy praktytsi davn'oho naselennya Bukoviny. Memoria ethnologica, 28-29, 104-108.

Pyvovarov S.V., Il'kiv M.V. (2014). «Hromovi strily» u systemi yazychnyts'kykh i khrystyyans'kykh viruvan' seredn'ovichnoho naselennya Bukovyny. W: K.K. Krayniy (red.), Tserkva - nauka - suspil'stvo: pytannya vzayemodiyi. Na poshanu kyyivs'koho mytropolyta Yevheniya (Bolkhovitinova). Materialy Dvanadtsyatoyi Mizhnarodnoyi naukovoyi konferentsiyi (7-8). Kyyiv: Natsional'nyy Kyyevo-Pechers'kyy istoryko-kul'turnyy zapovidnyk.

Quast D. (2011). Ein Steinbeil mit magischer Inschrift aus der Sammlung des Prinzen Christian August von Waldeck. Archäologisches Korrespondenzblatt, 41(2), 249-261. 
Quintía Pereira R. (2009). A pedra da pezoña e outras pedras sandadoras da cultura popular galega. Galicia Encantada, 5 [http://www.galiciaencantada.com/archi vos/docs/1555_Apedradapezo\%C3\%B1aeoutraspe drassandadorasdaculturapopulargalega.pdf] - dostęp dn. 15.04. 2020.

Rafn C.Ch. (1854). Bemarkninger om en steenöxe med runeindskrift, tilhörende Hans Majestcet kongen. Kjöbenhavn: Thieles bogtrykkeri.

Ramminger B. (2007). Blitzschutz und Fruchtbarkeitsspender: noch einmal zu den „Donnerkeilen“. Denkmalpflege und Kulturgeschichte, 4, 11-13.

Ramsey G. (1995). Rubbing Stones, Raths and Polished Stone Axes. Archaeology Ireland, 9(2), 9-10.

Rebmann T. (2006). Les haches néolithiques. W: M. Reto et al. (red.), Develier-courtételle un habitat rural mérovingien 3: céramiques et autres objets en pierre, verre, os, bois ou terre cuite (138-139). Porrentruy: Office de la culture de la Republique et Canton du Jura, Societe jurassienne d'Emulation.

Reitinger J. (1976). „Donnerkeile“ aus Oberösterreich und Salzburg. Archaeologia Austriaca, 13-14, 511-546.

Ribon P. (1993): Pierres qui guérissent. Lyon: Editions Horvath.

Riess W. (1981). Ein Donnerkeil aus Wels. Jahrbuch des Musealvereines Wels, 23, 41-52.

Rosmanitz H. (2006). Die archäologischen Untersuchungen auf der Ketzelburg - Ein Überblick. W: H. Rosmanitz (red.), Die Ketzelburg in Haibach. Eine archäologisch-historische Spurensuche (55-70). Neustadt a.d. Aisch: Verlag Schmidt.

Roth Th. (2006). Als die Donnerkeile noch vom Himmel fielen. W: H. Rosmanitz (red.), Die Ketzelburg in Haibach. Eine archäologisch-historische Spurensuche (107-111). Neustadt a.d. Aisch: Verlag Schmidt.

Rötting H. (1985). Stadtarchäologie in Braunschweig. Ein fachübergreifender Arbeitsbericht zu den Grabungen 1976-1984. Hameln: Verlag CW Niemeyer.

Rozhdestvenskaya T.V. (2001). Nadpisi na predmetakh. W: S.V. Beletskiy, V.A. Lapshin (red.), Tverskoy kreml': kompleksnoye arkheologicheskoye istochnikovedeniye (211-216). Sankt-Peterburg: Yevropeysiy Dom.

Rúa Aller F.J., García Armesto M.J. (2010). Usos y creencias de las piedras de rayo de León. Revista de Folklore, 344, 61-68.

Rustoiu A. (2015). Shooting the evil. "Scythian" arrowheads in Avar age graves from the Carpathian Basin. W: C. Cosma (red.), Warriors, weapons, and harness from the $5^{\text {th }}-10^{\text {th }}$ centuries in the Carpathian Basin (89-106). Cluj-Napoca: Mega Publishing House.
Rynne E. (1964-1965). Two stone axeheads from Killamoat Upper, Co. Wicklow. Journal of the County Kildare Archaeological Society, 14(1), 50-53.

Sachße C. (2006). Donnerkeile in der Apotheke. Deutsche Apothekenmuseum, 31(1), 5.

Sachße C. (2008). Mit der Streitaxt gegen die Gelbsucht? Archaeologica als Arzneimittel in historischer Zeit. W: F. Falkenstein, S. Schade-Lindig, A. Zeeb-Lanz (red.), Kumpf, Kalotte, Pfeilschaftglätter. Zwei Leben für die Archäologie. Gedenkschrift für Annemarie Häußer und Helmut Spatz (227-244). Rahden/Westf.: Verlag Marie Laidorf.

Saintyves P. (1936). Pierres magiques: Bétyles, HachesAmulettes et Pierres de Foudre. Traditions savantes et Traditions populaires. Paris: Librairie Émile Nourry.

Salin E., France-Lanord A. (1946). Traditions et art mérovingiens I. Le cimetière de Varangéville (Meurthe-etMoselle). Gallia, 4, 199-245.

Salo U. (1990). Agricola's Ukko in the light of archaeology A chronological and interpretative study of ancient Finnish religion. W: T. Ahlbäck (red.), Old Norse and Finnish Religions and Cultic Place Names (92-190). Åbo: Donner Institute for Research in Religious and Cultural History.

Samariter R. (2014). Das Beil auf dem Balken. Ein Fund aus Horst bei Greifswald, Lkr. Vorpommern-Rügen. Archäologische Berichte aus Mecklenburg-Vorpommern, 21, 215-217.

Samdal M. (2000). Amuletter. Gjenstander med amulettkarakter $i$ vestnorske graver I tidsrommet 350-1000 e. Kr. Bergen (niepublikowana rozprawa doktorska). [http://bora.uib.no/bitstream/handle/1956/1785/Mas teroppgave-samdal.pdf? sequence $=1 \&$ isAllowed $=y$ ] - dostęp dn. 05.02.2020.

Schoknecht U. (1964). Kurze Fundberichte 1963. Bezirk Neubrandenburg. Bodendenkmalpflege in Mecklenburg, 1964, 353-389.

Schoknecht U. (1978). Kurze Fundberichte 1977. Bezirk Neubrandenburg. Bodendenkmalpflege in Mecklenburg, 1978, 355-417.

Schoknecht U. (2005). Die Axt am Webstuhl. Archäologische Berichte aus Mecklenburg-Vorpommern, 12, 5-6.

Schuh C.P. (2007). Mineralogy \& Crystallography: On the History of the Sciences from Beginning through 1919. Tucson: Library of Congress Cataloging in Publication Data.

Schultrich S. (2018). Das Jungneolithikum in SchleswigHolstein. Leiden: Sidestone Press.

Sébillot P. (1904). Le folklore de France 1: Le ciel et la terre. Paris: Libraire Orientale \& Américaine. 
Sedova M.V. (1957). Amulet iz drevnego Novgoroda. Sovetskaya arkheologiya, 4, 166-167.

Seonbok Y. (2002). „Thunder-Axes” and the traditional view of Stone Tools in Korea. Journal of East Asian Archaeology, 4(1-4), 293-306.

Seyfahrt C. (1913). Aberglaube und Zauberei in der Volksmedizin Sachsens. Ein Beitrag zur Volkskunde des Königsreichs Sachsen. Leipzig: Verlag von Wilhelm Heims.

Sheridan A., Cooney G., Grogan E. (1992). Stone axe studies in Ireland. Proceedings of the Prehistoric Society, 58, 389-416.

Sheridan A., Pailler Y., Pétrequin P., Errera M. (2011). Old friends, new friends, a long-lost friend and false friends: tales from Project JADE. W: Davis V., Edmonds M. (red.), Stone Axe Studies 3 (411-426). Oxford: Oxbow Books.

Shevelev V.V. (2005). Gromovye strely" proroka Il'ia. Etnograficheskie realii. Zhivaya starina, 1, 2-3.

Siegmund F. (1998). Merowingerzeit am Niederrhein. Die frühmittelalterlichen Funde aus dem Regierungsbezirk Düsseldorf und dem Kreis Heinsberg. Köln-Bonn: Rheinland-Verlag.

Sielski S. (1941). Hamajlije. Etnografska istraživanja i građa, 3, 81-120.

Sieradzki A. (2017). Teonim Perun w leksyce średnio- i nowopolskiej (na podstawie słowników). Język. Religia. Tożsamość, 1(15), 199-211.

Sikora M. (1966). Szczecinek - stanowisko 3. Materiaty Zachodniopomorskie, 12, 792-793.

Simpson J., Roud S. (2000). A Dictionary of English Folklore. Oxford: Oxford University Press.

Sklenář K. (1986). Okresní muzeum v Rokycanech. Katalog pravěké sbírky. Zprávy Čs. společnosti archeologické při ČSAV, 31, 1-33.

Sklenár̆ K. (1999). Hromové klíny a hrnce trpasliků. Z pokladnice české folklorní archeology. Praha: Set Out.

Sklenáŕ K. (2018). Počátky archeologie v Čechách. Od prvnich kronik na práh období romantismu (12.-18. stoleti). Die Anfänge der Archäologie in Böhmen. Seit den ersten Chroniken bis zur Schwelle der Periode des Romantismus (12.-18. Jahrhundert). Praha: Národní muzeum.

Skutil J. (1932). Dva přispěvky k československému folkloru prehistorickému. Český lid, 32, 35-52.

Skutil J. (1963). Opracujmy słowiański folklor prahistoryczny. Pradzieje Słowiańszczyzny w słowiańskich wyobrażeniach ludowych. Z Otchłani Wieków, 29(1), 84-87.

Snædal T., Stocklund M., Åhlén M. (1988). Runfynd 1987. Fornvännen, 83, 234-50.
Søyland K. (2007). Toresteinar. Ei undersøking av utbreiinga av eldre gjenstander av stein, sekundært deponert i jernalderkontekstar i Vest-Noreg. Bergen (niepublikowana praca magisterska). [http://bora.uib.no/handle/1956/17518] - dostęp dn. 10.04.2020

Søvsø M., Søvsø M.H., Siggaard A.L. (2016). Om hugorme, dyrekranier og tordensten - bygningsofre og andre skikke med dybe rødder i folketroen. By Marsk og Geest, 28, 57-89.

Ströbele W. (1992). Informationsblatt. Beiträge zu Objekten, Ausstellungen und historischen Themen 4. Reutlingen: Stadt Reutlingen, Schul-, Kultur- und Sportamt, Heimatmuseum.

Szafrańska A. (2016). Jak kamień piorunowy stał się belemnitem, a fulguryt kamieniem piorunowym. W: J. Przyklenk, W. Wilczek (red.), Bogactwo polszczyzny $w$ świetle jej historii 6 (100-108). Katowice: Wydawnictwo Uniwersytetu Śląskiego.

Szczepański S. (2010). Kamień i skała w mitologii, wierzeniach i obyczajowości ludów indoeuropejskich. W: R. Klimek, S. Szczepański (red.), Kamienie w historii, kulturze i religii (7-23). Olsztyn: Robert Klimek.

Szeremeta M. (2019). Siekiera kamienna. W: M. Majewski (red.), Archeologia Stargardu 5(1): Badania kwartału IX najstarsze ślady osadnictwa (49-52). Poznań-Stargard: Bogucki Wydawnictwo Naukowe.

Szyfer A. (1969). Tradycyjna astronomia i meteorologia ludowa na Mazurach, Warmii i Kurpiach i jej wspótczesne przeobrażenia. Olsztyn: Pojezierze.

Šantalab D. (2008). Kamena strela. Neka vjerovanja seljaka s područja Višnjice o kamenom oruđu i oružju iż neolitika i eneolitika. Ivanečka škrinjica, 4, 34-36.

Šimek F. (1909). O hromovém kameni. Český lid, 18, 458459.

Šimek M. (2010). „Kamena strela” u srednjovjekovnoj utvrdi?. Zbornik Soboškega muzea, 15, 135-149.

Šmitek Z. 2007. Kaj raste brez korenja? O kamnih s posebnimi svojstvi na Slovenskem. Studia Mythologica Slavica, 10, 179-195.

Taggart D. (2018). How Thor Lost His Thunder. The Changing Faces of an Old Norse God. London-New York: Routledge.

Thäte E.S., Hemdorff O.H. 2009. Økser, amuletter og overtro: en steinalderøks i jernaldergrav på Avaldsnes, Karmøy. W: M. Nitter, E.S. Pedersen (red.), AmS-Varia 49 (43-52). Stavanger: Universitetet i Stavanger, Arkeologisk museum.

Toeppen M. (1867). Aberglauben aus Mazuren mit einem Anhange, enthaltend: Masurische Sagen und Mährchen. Danzig: Verlag von Th. Bertling. 
Tolstoy N.I. (1995). Gromovaya strela. W: N.I. Tolstoy (red.), Slavyanskie drevnosti 1 (561-563). Moskva: Mezhdunarodnye otnosheniya.

Trigger B.G. (2006). A History of Archaeological Thought, 2. wyd. Cambridge: Cambridge University Press.

Tsapko A.V. (2017). Belemnity. Zv'yazok mizh slovom ta svitohlyadno-mifolohichnym kontekstom. W: I.H. Vodolazs'ka (red.), Materialy XII rehional'noyi naukovopraktychnoyi students 'koyi konferentsiyi "Ukrayins'ka molod'. Dukhovnist'. Moral'. Hromadyans'kist,", (128-131). Rubizhne: Rubizhans'kyy politekhnichnyy koledzh im. O.YE. Poray-Koshytsi Luhans'koho natsional'noho universytetu im. Tarasa Shevchenka.

Tuijn W. (1992). Middeleeuws hergebruik van stenen bijl? Jaarverslag, 25, 40-41.

Tumènas V. (2016). The common attributes between the Baltic Thunder god Perkūnas and his antique equivalents Jupiter and Zeus. Mediterranean Archaeology and Archaeometry, 16(4), 359-367.

Tyanina E.A. (2008). Orudiya kamennogo veka v kul'turnom sloye srednevekovogo Novgoroda: predmety yazycheskogo kul'ta ili sluchaynyye veshchi? W: V.L. Yanin (red.), Novgorod i Novgorodskaya zemlya. Istoriya $i$ arkheologiya. Materialy nauchnoy konferentsii 22 (172-183). Velykyy Novhorod: Novgorodskiy gosudarstvennyy ob"yedinennyy muzey-zapovednik.

Tyanina E.A. (2018). K voprosu o kul'te Peruna v Novgorodskoy zemle (po materialam arkheologicheskogo issledovaniya Novgoroda). Colloquia Russica, 1(8), 59-72.

Unger J(osef). (1999). Život na lelekovickém hradě ve 14. století. Antropologická sociokulturní studie. Brno: Universitas Masarykiana.

Unger J(iří). (2007). Druhotné využití staršich archeologických artefakti̊ v mladším období. Plzen: Katedra archeologie Fakulta filozofická Západoceské univerzity v Plzni (niepublikowana praca magisterska). [https://www.academia.edu/12412788/Druhotn $\%$ C3\%A9_vyu\%C5\%BEit $\%$ C3\%AD_star\%C5\%A1 $\% \mathrm{C} 3 \% \mathrm{ADch}$ archeologick $\% \mathrm{C} 3 \% \mathrm{BDch}$ artefakt $\%$ C 5\%AF_v_mlad $\%$ C5\%A1\%C3\%ADm_obdob \%C3\%AD] - dostęp dn. 20.05.2019.

Ungerman Š. (2009). Archaika in den frühmittelalterlichen Gräbern in Mähren. W: P. Maříková Vlčková, J. Mynářová, M. Tomášek (red.), My Things changed Things. Social Development and Cultural Exchange in Prehistory, antiquity, and the Middle Ages (224-256). Prague: Charles University in Prague, Faculty of Arts; Institute of Archaeology of the Academy of Sciences of the Czech Republic, Prague.
Valentsova M.M. (2018). "Kamennaya moya golova...”: ob odnom obychaye pri pervom grome. Zhivaya starina, 4, 6-9.

Vařeka P. (1991). Stavební obětiny z české a moravské vesnice v archeologických pramenech. Český líd, 78(2), 117-119.

Vasks A. (2003). The symbolism of stone work-axes (based on material from the Daugava Basin). Archaeologia Lituana, 4, 27-32.

Verhart L. (2015). Vuurstenen werktuigen. W: T. Derks, B. de Fraiture (red.), Een Romeins heiligdom en een vroegmiddeleeuws grafveld bij Buchten (L). Verslag van een archeologisch noodonderzoek (1976) (83-86). Amersfoort: Rijksdienst voor het Cultureel Erfgoed.

Verhart L. (2016). Vondsten, vindplaatsen en verhalen: geneeskrachtige bijlen. De Maasgouw, 135, 6-10.

Vesly L. de. (1909). La fana ou petits temples Gallo-romains de la région Normande. Rouen: Imprimerie J. Lecerf Fils.

Vích D., Kašpar P. (2014). Nález hromového klínu v Panoším Újezdu na Rakovnicku. Archeologie ve střednich Čechách, 18, 901-902.

Vilsteren van V.T. (2011). In de greep van de bisschop. De Maartenshamer. Waardeel, 31(4), 15-16.

Waszk B. (2014). Lithoglyphi artefacti - Gemachte Formen oder Bildsteine. W: U. Veit, M. Wöhrl (red.), Donnerkeil - Opfermesser - Thrängefäß. Die archäologischen Objekte aus der Sammlung der Leipziger Apothekerfamilie Linck (1670-1807) im Naturalienkabinett Waldenburg (Sachsen) (41-43). Lepzig: Professur für Ur- und Frügeschichte.

Watte J.-P., Jullien M. (2007). Un biface employe comme "ceraunie" ou "pierre de foudre" a Livet-sur-Authou (Eure). Haute-Normandie Archéologique, 12, 5-8.

Way A. (1868). Supplementary Notes on Celts and other Implements used as Talismans. The Archaeological Journal, 25, 116-118.

Wdowiak L., Wysokiński P. (2013). Piorunowe strzałki, grzmoty i gromy w medycynie ludowej na ziemiach polskich w okresie rozbiorów. W: M.Z. Felsmann, J. Szarek, M. Felsmann (red.), Dawna medycyna $i$ weterynaria. Środowisko a człowiek (519-545). Chełmno: Muzeum Ziemi Chełminskiej w Chełmnie.

Wessman A. (2009). Reclaiming the Past: Using old artefacts as a Means of Remembering. W: A. Šnē, A. Vasks (red.), Interarchaeologia 3. Papers from the Third Theoretical Seminar of the Baltic Archaeologist (BASE) held at the University of Latvia, October 5-6, 2007. Memory, society, and Material Culture (71-88). Riga-Helsinki-Tartu-Vilnius: University of Latvia, 
University of Helsinki, University of Tartu, University of Vilnius.

Zheltova M.N., Tarabardina O.A., Tyanina E.A., Musin A.E. (2015). Kamennyye artefakty epokhi neolita i rannego zheleznogo veka iz kul'turnogo sloya srednevekovogo Novgoroda: kharakter vtorichnoy depozitsii i osobennosti ispol'zovaniya. W: S.A. Vasil'yev, V.Ye. Shchelinskiy (red.), Metody izucheniya kamennykh artefaktov. Materialy mezhdunarodnoy konferentsii Sankt-Peterburg 16-18 noyabrya 2015 g. (213-217). Sankt-Peterburg: Institut istorii material'noy kul'tury RAN.
Zheltova M.N., Tarabardina O.A., Tyanina E.A., Musin A.E. (2017). Kamennyye artefakty epokhi neolita i rannego zheleznogo veka iz kul'turnogo sloya srednevekovogo Novgoroda: kharakter vtorichnoy depozitsii i osobennosti ispol'zovaniya. W: S.A. Vasil'yev, V.Ye. Shchelinskiy (red.), Drevniy chelovek i kamen'. Tekhnologiya, forma, funktsiya (236-241). Sankt-Peterburg: Peterburgskoye vostokovedeniye.

Zoller D. (1981). Beiträge zur archäologischen Landesaufnahme für den Landkreis Ammerland Gemeinde Apen (I). Oldenburger Jahrbuch, 81, 277-302.

\section{TOMASZ KURASIŃSKI}

\section{STONES BORN OF LIGHTNING. ON AN UNUSUAL FORM OF RECYCLING IN THE MIDDLE AGES AND MODERN TIMES}

\section{SUMMARY}

Among finds whose former purpose has been forgotten, and whose shape at the same time, despite possible interference with its structure, still allows formal and chronological identification, are prehistoric stone objects obtained and collected in the Middle Ages and modern times (mainly various types of axes, hammers, adzes, and hammers axes, usually from the Neolithic, less often from other periods). This article discusses their meaning in completely different cultural realities. An attempt was made to answer to what extent folkloric information and ethnographic data concerning the cultural significance and functions of these re-used objects are reflected in medieval and modern historic materials.

The items in question are usually referred to as "thunderstones", although many semantic and synonymous equivalents are known, depending on the language and the region. Most of the terms are comprised of two-parts, the first of which generally refers to the feature of the object (elongated and pointed at the end), while the second emphasizes its relationship with lightning, the devil, and less often - with God and the saints. Some of the names evoke more distant layers of meaning, and disclose a relationship with the thunder deity, whose attribute was imagined as either a stone, axe, mace, or chisel.

It is worth remembering that under the terms used in the past, other finds may be hidden, mainly fossils of organic origin, especially belemnites and echinites. Due to the ambiguous nature of thunderstones, it is not always possible to be sure which specific type of find occurs under a given name.

Finds from almost all over Europe were taken into account. The presented overview of the finds, although far from complete, allows us to indicate the main regions of their occurrence, giving an idea of the scale of the phenomenon under study, both in chronological and territorial terms.

Thunderstones are discovered in various places of residential, farm, and religious buildings (mainly in walls, basements, and chimneys, as well as under the floor, under the threshold, in the foundations, and on the roof), both in cities, castles, and fortified settlements, as well as in villages. Sometimes they were placed in bridges and defensive walls, as well as in wells, graves, treasures, under streets, and along water courses. This translates into the content attributed to thunderstones and the forms of their use in new cultural realities.

Traditional ideas about all kinds of thunderstones focused primarily on an atmospheric phenomenon - a thunderstorm with accompanying light and sound effects, i.e., lightning and thunder. In European folk tradition it was believed that these objects fall to the ground from the sky in the form of lightning or with lightning, or are formed from melted sand at the point of its impact on the ground. Wherever stone tools were somehow associated with lightning, they were considered projectiles. It was believed that thunder was caused as they were driven deep into the ground. 
There are clear mythological references through connotations with the thunder gods and their attributes in the form of weapons identified with thunder and lightning.

The mythical and belief-based image of the world associated with these products was not limited only to the mindset of uneducated social classes. For a long time, no clear distinction was made between natural creations and those that were of human origin, in the belief that the ancient stone tools were thunderstones or elf-arrows shot from the sky. Not until the end of the 17th and 18th centuries did some scholars begin to openly question the genesis of prehistoric stone products and put forward arguments for their proper interpretation.

Despite scientific clarification of the origin of thunderstones, this did not have any impact on the popular belief about lightning in folk culture, wherein the magical power of these objects persisted for much longer, as evidenced by folkloric information from the nineteenth and early twentieth centuries. It was seldom realized that these were man-made products: what mattered was their supernatural origin.

Due to the origin of thunderstones from the heavenly realm, it becomes understandable that their primary function was to protect against lightning and the destructive effects of storms. The casting of these creations in this role is deeply rooted in the past and observed in many cultures - indeed, it has an almost global reach. This is due to the widespread conviction that lightning never strikes twice in the same place.

It was therefore deemed wise to place objects considered to be thunderstones at various points in the house and farm buildings, as well as in city walls and fortifications, including sacred buildings. Such measures were taken above all to protect the space most exposed to a lightning strikes and, as a result, to fire - namely, the roof with its culminating element, the chimney. These items were also carefully hidden in walls, under the floor and the threshold, which ensured that they would be covered by all border locations in the household and farm.

Apart from the location within the household or other types of buildings, it is difficult to say, based only on the features of the object, whether it fulfilled the above-described protective function.

Placing thunderstones in foundations, basements, under floors, thresholds, or poles evinces some features of a foundation offering. It seems that depositing the items in question as such, if it took place at all, was practiced incidentally.

The conviction that stone products from prehistoric times exhibit protective properties translated into the attribution of a generally beneficial effect on the household and its inventory. The lucky finder was protected not only from storms, but also from diseases, charms, nightmares, and all evil. It was therefore worn as a personal amulet. In the above context, perforated copies from the Middle Ages deserve attention.

A wide range of magical treatments that related to stone artifacts of ancient origin also took into account the welfare of animals and cultivated plants. Their task was to protect them against diseases, as well as to ensure fertility and harvest.

The magical effectiveness of thunderstones was emphasized, strengthened, and supported by various symbols and representations made in much later cultural realities (e.g., runes, pentagrams, letters). Particularly noteworthy are Christian motifs, such as images of the cross or figures of saints, Christ, or the Virgin Mary. One should also mention the oft times illegible dates given in years, the deciphering of which can be a guessing game.

Prehistoric stone products were widely used in folk medicine, which generally did not differ much from magical practices. Particular value was assigned to the powder scraped off the item that was recommended for various diseases. In light of the records we have, this form of medicine was widely used in traditional medicine. In general, thunderstones were applied to the diseased parts of the body, often accompanied by the uttering of spells. Stone archaica was used to treat domestic animals, especially cattle.

The powdered form of the medicine, widely used in folk medicine and veterinary medicine, had to leave traces in the form of scratches or cavities resulting from its acquisition. They are visible on specimens from both the Middle Ages and modern times.

The collection of prehistoric stone products discovered in burials is much inferior in number to those deposited elsewhere. The scarcity of these archaics among grave goods is justified by their impracticality (unwieldiness), i.e., the inability to hang, or possibly hide in pouches hung at the belt. None of the burial thunderstones known to us are perforated or otherwise designed to be worn on the body. Therefore, it should rather be excluded that they were located on the neck or chest of the deceased. It is worth emphasizing, however, the size diversity of the specimens (range from $6 \mathrm{~cm}$ to over $14 \mathrm{~cm}$ ). This may indicate different functions performed in the tomb, but it is difficult to determine. In the literature on the subject, the magical and ceremonial meaning is usually emphasized. Some of the items could be used as whetstones.

Other reasons could also have influenced the change in the original form of the products in question. These items were divided and then separated, thanks to which mutual relations and bonds were symbolically maintained. Some- 
times they were traded, sometimes brought from places of pilgrimage, e.g., Mariazell in Austria. They gained significant economic value, which could lead to the counterfeiting of real specimens. It is also worth pointing to the secondary use of Neolithic stone utensils in later ceremonial weapons, e.g., the hammer of St. Martin.

With time, beliefs about the magical-apotropaic and healing powers of thunderstones became a thing of the past. This process was not the same everywhere and probably had local conditions. It seems, however, that the end of the 19th century marked a rapid erosion of faith in the objects in question, although here and there its continuation should be taken into account, especially in the traditional rural environment. With the loss of confidence in the supernatural properties of thunderstones, three directions of their further treatment can be expected. They could be seen as a kind of family heirloom, often passed down from generation to generation, stored out of sentiment or for good luck. One sign of the disappearance of the sacred importance of prehistoric stone tools was their practical use, e.g., as weaving weights, candlesticks, clock pendulums, hammers, butter weights, whetstones, toys, and linen smoothers.

The presented archaeological and written sources, ethnographic data, and accidental finds show a wide repertoire of possibilities for the onetime use of these objects. Along with the acquisition of new meanings, these objects partici- pated in human actions and relationships when they were deliberately sought, conveyed, and used within the framework of the expressed worldview. This is due to the adoption of the concept of affordances, generally understood as an interaction between people and objects that exhausts all possible utilization. The preliminary attempt made in this paper to confront the discussed finds with traditional accounts, showing them in specific ritual and magical activities and behaviors, shows that despite the difficulties in recognizing their meaning on the basis of the contexts of occurrence and traces or secondary changes in appearance, made according to the current requirements and needs, we can nonetheless discern certain elements of the universality and continuity of the related ideas, particularly when observed in the long term. Their usage resulted primarily from the need to magically protect oneself and one's property.

In the Middle Ages and later, thunderstones gained a great deal of importance, as there were few items that, after their original function had disappeared, remained in such wide use, far beyond the traditionally understood recycling, which is usually limited to the re-use of raw materials and remedial actions. As objects with a strong sacral significance, they found a permanent place in the rituals and concepts of ancient communities.

Otrzymano (Received): 21.09.2020; zrecenzowano (Revised): 10.11.2020; zaakceptowano (Accepted): 19.11.2020

Adres Autora:

Dr Tomasz Kurasiński

Ośrodek Badań nad Dawnymi Technologiami Instytut Archeologii i Etnologii PAN

ul. Tylna 1; 90-364 Łódź

e-mail: tomasz.kurasinski@wp.pl

(iD https://orcid.org/0000-0002-8158-1104 